\author{
UNIVERSIDADE DE SÃO PAULO \\ PROGRAMA DE PÓS-GRADUAÇÃO EM ENERGIA \\ ( EP-FEA-IEE-IF )
}

A LOGÍSTICA DO ETANOL DE CANA-DE-AÇÚCAR NO BRASIL: CONDICIONANTES E PERSPECTIVAS

CLAUDIO MITSUTANI

SÃO PAULO

2010 
CLAUDIO MITSUTANI

\section{A LOGÍSTICA DO ETANOL DE CANA-DE-AÇÚCAR NO BRASIL: CONDICIONANTES E PERSPECTIVAS}

Dissertação apresentada ao Programa de PósGraduação em Energia da Universidade de São Paulo (Escola Politécnica / Faculdade de Economia e Administração / Instituto de Eletrotécnica e Energia / Instituto de Física) para a obtenção do título de Mestre em Energia.

Orientador: Prof. Dr. José Aquiles Baesso Grimoni

\section{SÃO PAULO}




\section{AUTORIZO A REPRODUÇÃO E DIVULGAÇÃO TOTAL OU PARCIAL DESTE TRABALHO, POR QUALQUER MEIO CONVENCIONAL OU ELETRÔNICO, PARA FINS DE ESTUDO E PESQUISA, DESDE QUE CITADA A FONTE.}

FICHA CATALOGRÁFICA

Mitsutani, Claudio.

A Logística do Etanol de Cana-De-Açúcar no Brasil:

Condicionantes e perspectivas / Claudio Mitsutani; orientador José Aquiles Baesso Grimoni - São Paulo, 2010.

103f.: il.; $30 \mathrm{~cm}$.

Dissertação (Mestrado - Programa de Pós-Graduação em Energia) EP / FEA / IEE / IF da Universidade de São Paulo.

1. Etanol 2. Energia de Biomassa 3. Fontes alternativas de energia I. Título. 


\section{UNIVERSIDADE DE SÃO PAULO \\ PROGRAMA DE PÓS-GRADUAÇÃO EM ENERGIA \\ EP - FEA - IEE - IF}

CLAUDIO MITSUTANI

"A logística do etanol de cana-de-açúcar no Brasil: condicionantes e perspectivas"

Dissertação defendida e aprovada em 24/02/2010 pela Comissão Julgadora:
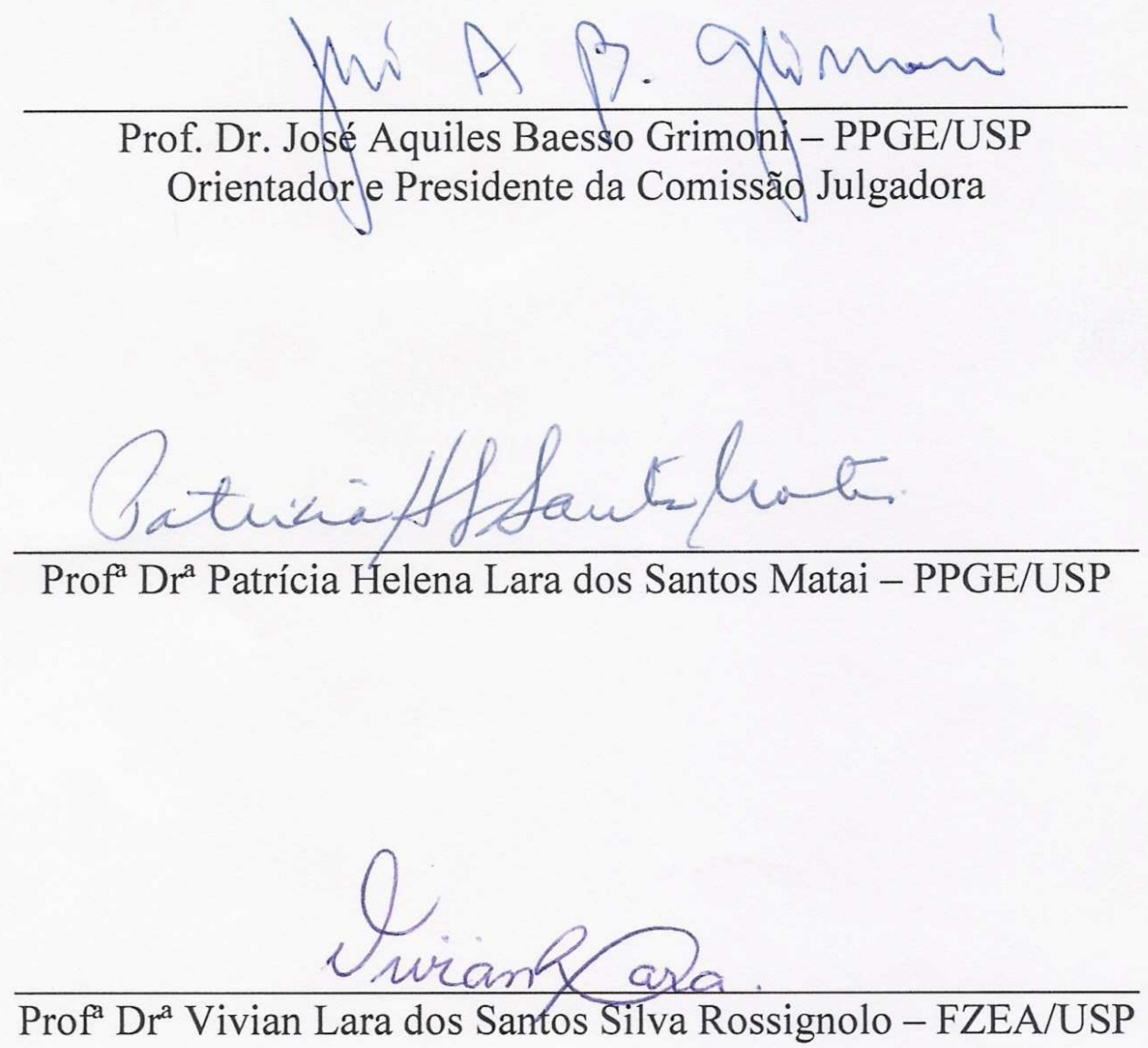
Aos meus queridos pais que sempre me apoiaram em todos os momentos e em todas as situações de minha vida dedico este trabalho com amor e respeito. 


\section{AGRADECIMENTOS}

Ao caríssimo Professor Aquiles pelo apoio, paciência e respeito no desenvolvimento deste trabalho. Particularmente saliento e agradeço seu espírito e atitude de Professor que a mim servem de exemplo para minha carreira acadêmica.

Aos professores e funcionários do PIPGE - USP, por todo o apoio para a realização deste trabalho.

À Fátima, da biblioteca do IEE, pelo apoio na revisão bibliográfica.

Aos colegas de turma do PIPGE pelo convívio e amizade neste período.

Aos meus pais, familiares e amigos que sempre me apoiaram, e cobraram, a realização deste trabalho.

Ao Paulo Kanayama pela sua bondade e pureza no trato neste período.

Ao Maurício e Bruno da Agra-FNP pelo auxílio nas informações e discussões relevantes a este trabalho.

Aos colegas e parceiros da Atman que diretamente ou indiretamente apoiaram o desenvolvimento deste trabalho

Aos profissionais de empresas e de associações do setor sucroenergético e de logística pelas conversas e informações relevantes a este trabalho. 


\section{RESUMO}

MITSUTANI, C. , A Logística do Etanol de Cana-de-açúcar no Brasil : condicionantes e perspectivas . 2010, 102 p. Dissertação (Mestrado em Energia) - Programa de Pós-Graduação em Energia da Universidade de São Paulo, São Paulo, 2010

O presente trabalho apresenta e analisa cenários para os próximos anos para a expansão da demanda do etanol a base de cana de açúcar no Brasil, considerando a influência dos condicionantes envolvidos e os conseqüentes impactos, necessidades e alternativas futuras na logística de distribuição deste insumo energético no Brasil. Mais especificamente apresenta o histórico e a evolução da cultura da cana-de-açúcar no Brasil e nos principais países produtores e consumidores dos derivados da cana-de-açúcar, aspectos produtivos relacionados á produção de etanol. Apresenta ainda os condicionantes para a demanda do etanol produzido no Brasil e as necessidades decorrentes de infra-estrutura logística para a distribuição do etanol nos mercado interno e para exportação.

Palavras - chave: demanda de etanol , logística de etanol, energia renovável. 


\begin{abstract}
MITSUTANI, C. , Sugarcane ethanol logistics in Brazil ; drivers and perspectives . 2010, 102 p. . Master's Dissertation - Graduate Program on Energy, Universidade de São Paulo, 2010.

This present work presents and analyses different scenarios for the following years for the demand expansion of sugarcane ethanol in Brazil. It considers the influence of different drivers involved and the consequent impacts, needs and future alternatives for distribution logistics of this energy source in Brazil. More specifically, this work presents historical evolution of sugarcane culture in Brazil and in other main producers and consumers of sugarcane products, productive aspects related to ethanol production . It presents drivers to the demand expansion of the ethanol produced in Brazil and the related needs of infrastructure and logistics for the ethanol distribution in the Brazilian local market and export markets.
\end{abstract}

Key - words: ethanol demand, , ethanol logistics, renewable energy. 


\section{Lista de Figuras}

Página

Figura 1 - Cana-de-açúcar $\quad 19$

Figura 2 - Distribuição de usinas de cana-de açúcar no Brasil 21

Figura 3 - Distribuição da produção entre açúcar e álcool no Brasil 22

Figura 4 - Evolução da produção de etanol no Brasil 24

Figura 5 - Evolução , em volume , das exportações brasileiras de álcool 24

Figura 6 - Produção Brasileira de Açúcar 25

Figura 7 - Plano estratégico corporativo Petrobrás 2008 -2012 33

Figura 8 - Esquema ilustrativo do processo produtivo de uma usina de cana-de-açúcar 35

Figura 9- Evolução do consumo etanol anidro e hidratado no Brasil 37

Figura 10 - evolução de preço, base 100, do petróleo, preço gasolina, preço etanol

na ponta de consumo $\quad 39$

Figura 11 - Distribuição espacial da população brasileira- Censo demográfico $2000 \quad 49$

Figura 12 - Saldo de produção e consumo de etanol hidratado no Brasil , 2007 (mil m3) 50

Figura 13 - Distribuição geográfica da produção de milho e etanol nos EUA, $2006 \quad 51$

Figura 14 - Fluxo de distribuição logística do etanol no Brasil 52

Figura 15 - Distribuição geográfica de infra-estrutura de combustíveis líquidos no Brasil53

Figura 16 - Número de postos de venda de combustíveis no Brasil, por estado 53

Figura 17 - Modelo conceitual - matriz de transportes 54

Figura 18- Rotas de entrega de longa distância de combustíveis e ferrovias planejadas 55

Figura 19 - Estrutura dutoviária brasileira e de países selecionados 57

Figura 20 - Custos genéricos de dutovias em função da vazão e diâmetro do duto 59

Figura 21 - Relação entre quantidade transportada, diâmetro do duto e custos de transporte $\quad 60$

Figura 22 - Programa Corredor de Exportação de Etanol Sudeste, Centro-Oeste e Sul 61

Figura 23 - Alternativa de escoamento Centro-Oeste Sul 62

Figura 24 - Projeto dutoviário da empresa Brenco 63

Figura 25- Novos projetos de expansão portuária - Transpetro 64

Figura 26 - Ilustração hidrovia Tietê- Paraná $\quad 64$

Figura 27 - Relação entre Demanda e oferta de etanol e necessidades 65

Figura 28 - Condicionantes da demanda do etanol no Brasil 67

Figura 29 - Participação por commodity no mercado futuro brasileiro, 2008

Figura 30- Potencial para plantação de cana de açúcar sem irrigação 73 
Figura 31 -Zoneamento do plantio da cana-de-açúcar 73

Figura 32 - Evolução da frota de veículos leves no Brasil por tipo de combustível 79

Figura 33 - Projeção de crescimento de demanda no mercado interno brasileiro de etanol para uso combustível $\quad 79$

Figura 34 - Projeção da importação de etanol por EUA - Cenário realista 80

Figura 35 - Projeção da importação etanol EU - Cenário Realista 81

Figura 36- Projeção da importação de etanol brasileiro pelo Japão - Cenário Realista 81

Figura 37- Projeção da importação de etanol brasileiro por demais países -

Cenário Realista

Figura 38 - Projeção da demanda total de etanol brasileiro - Cenário Realista

( bilhões de litros)

Figura 39 - Demanda interna etanol para uso combustível - Cenário otimista

( bilhões de litros)

Figura 40 - Projeção exportação etanol para Europa - Cenário otimista

( Bilhões de litros)

Figura 41 - Projeção de exportações de etanol brasileiro para o Japão -

cenário otimista (bilhões de litros)

Figura 42 - Projeção de demanda total de etanol brasileiro - cenário otimista

( bilhões de litros )

Figura 43 - Comparativo de projeções de demanda do etanol nos cenários realista , otimista e outros estudos similares ( bilhões de litros )

Figura 44 - Escala de viabilidade econômica de dutovias em função da distância e volume 
Tabela 1 - Produção mundial de cana-de-açúcar, 2005

Tabela 2 - Cana-de-açúcar moída no Brasil 20

Tabela 3 - Produção de cana - de - açúcar no Brasil na safra 2005/2006 21

Tabela 4 - Principais países produtores de etanol 23

Tabela 5 - Maiores países produtores de açúcar 25

Tabela 6 - Produção brasileira de bagaço, caldo e melaço de cana-de-açúcar 26

Tabela 7 - 14 maiores empresas sucroalcooleiras do Brasil na safra 2008/2009 29

Tabela 8 - Produção ,exportação e consumo interno de etanol no Brasil desde safra $2001 \quad 36$

Tabela 9 - Evolução da frota de automóveis e comerciais leves por tipo de Combustível no Brasil $\quad 38$

Tabela 10 - Principais produtores mundiais de etanol ( milhões de litros/ano) 41

Tabela 11 - Frota de veículos automotores leves e médios que utilizam combustível alternativo nos EUA, 2007

Tabela12 - Quantidade e extensão de dutos em operação, por função, segundo produtos movimentados, em 31/12/2008

Tabela 13 - Quadro Comparativo das Características Atuais da Produção do Etanol Celulósico e do Milho nos EUA $\quad 75$

Tabela 14 - Estimativa de aumento de oferta nos próximos anos no Brasil 90 
Lista de abreviações, siglas e unidades

ANEEL

ANFAVEA

ANP

ATR

BRIX

CAPEX

CBI

EBITDA

EIA

$\mathrm{EPE}$

GEE

GNV

HA

HP

IAA

IPI

IBGE

MAPA

NYSE

PAC

PROÁLCOOL

RFS

TON

UNICA
Agência Nacional de Energia Elétrica

Associação Nacional dos Fabricantes de Veículos Automotores

Agência Nacional do Petróleo

Açúcar Total Recuperável

Escala numérica que mede a quantidade de sólidos solúveis em uma solução de sacarose

\section{Capital expenditures}

\section{Caribbean Basin Iniciative}

Earnings before interests, tax, depreciation and amortization

Energy Information Adminstration

Empresa de Pesquisa Energética

Gases de Efeito Estufa

Gás Natural Veicular

Hectare ( $10.000 \mathrm{~m} 2)$

Horse power

Instituto do Açúcar e do Álcool

Imposto sobre produtos industrializados

Instituto Brasileiro de Geografia e Estatística

Ministério da Agricultura, Pecuária e Abastecimento

New York Stock Exchange

Programa de aceleração do crescimento

Programa de Incentivo ao Álcool

Renewable Fuels Standard

Tonelada ( $1000 \mathrm{~kg})$

União das Indústrias canavieiras de São Paulo 



\section{SUMÁRIO}

1 INTRODUÇÃ

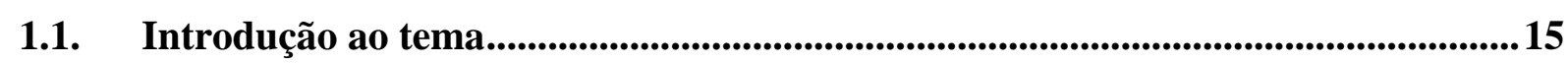

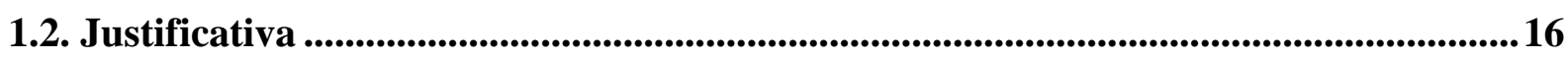

1.3 Objetivos.......................................................................................................................................... 16

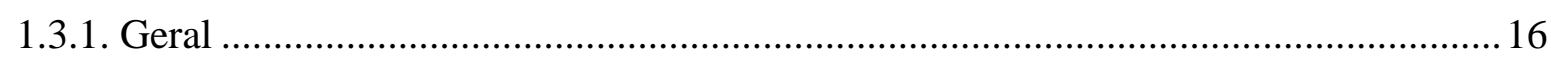

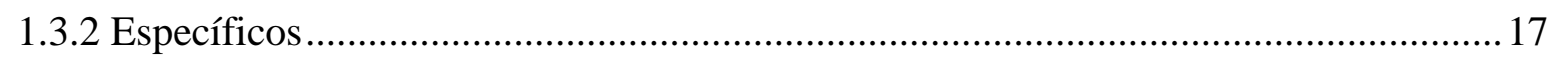

1.4 Metodologia de Pesquisa .............................................................................17

$1.5 \quad$ Estrutura do Trabalho ............................................................................................ 18

2. PESQUISA BIBLIOGRÁFICA E DE CAMPO .................................... 19

2.1. Produção da cana-de-açúcar e derivados .....................................................................19

2.1.1 Cana-de-açúcar ......................................................................................... 19

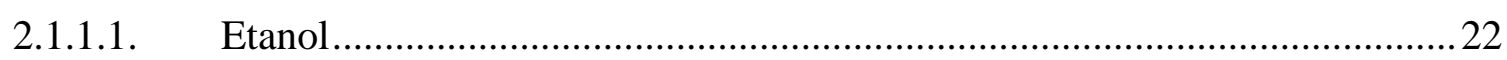

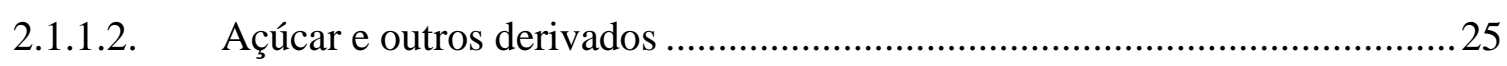

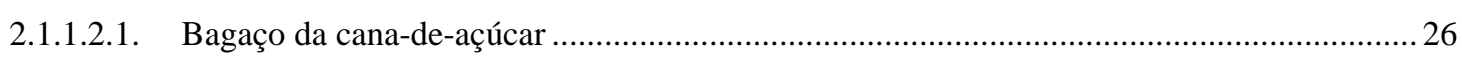

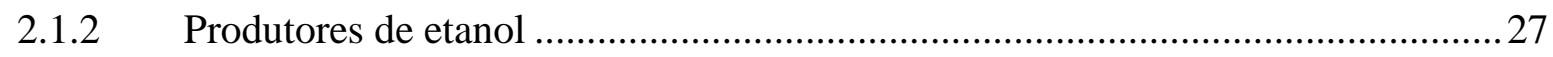

2.1.3 Características técnicas do cultivo e processamento ..............................................33

2.2 Questões e perspectivas dos principais mercados consumidores de etanol.............35

2.2.1 Mercado interno brasileiro e o flex fuel ............................................................... 35

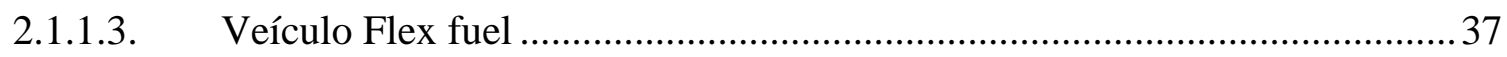

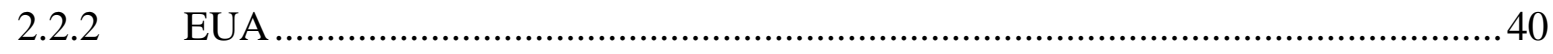

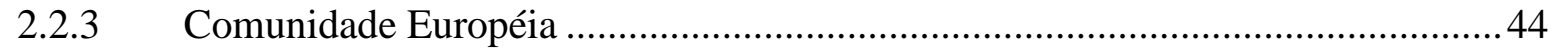

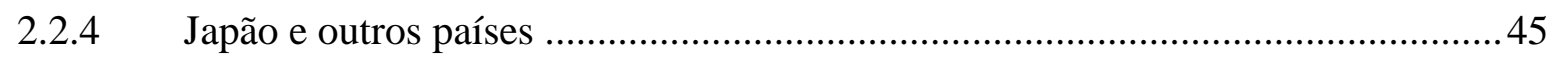

2.3 Logística de distribuição do etanol brasileiro .................................................................47

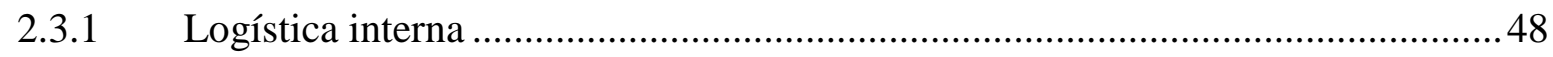

2.3.2 Logística para exportação e modal dutoviário..........................................................56 


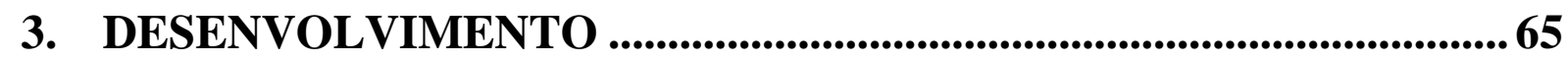

3.1. Modelagem da demanda de etanol e impactos na logística de distribuição...........65

3.1.1. Condicionantes para expansão da demanda do etanol e suas relações causais ....66

3.1.2. Cenários de expansão da demanda e análises................................................... 77

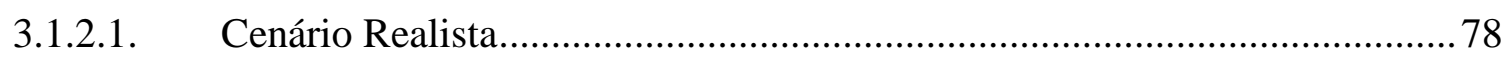

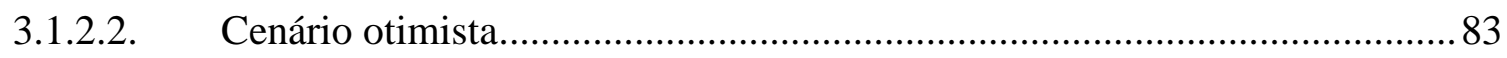

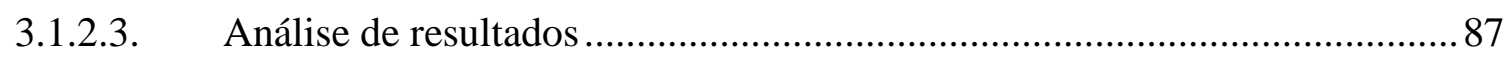

3.1.3. Impactos e necessidades na logística de distribuição .......................................91

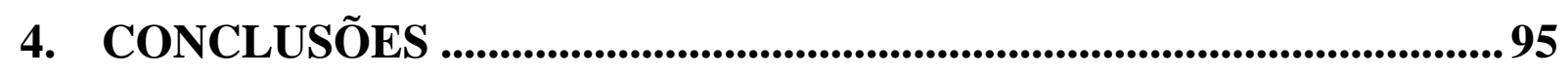

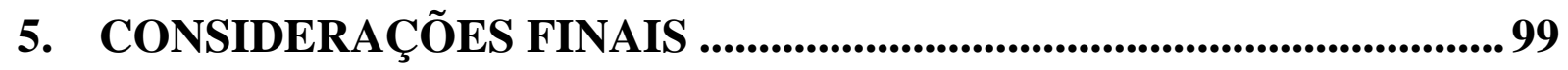

6. REFERÊNCIAS BIBLIOGRÁFICAS .................................................. 100 


\section{INTRODUÇÃO}

\subsection{Introdução ao tema}

A cultura da cana-de-açúcar tem tido crescimento significativo no Brasil nos últimos anos orientada pela demanda crescente do álcool combustível como substituto renovável de fontes não renováveis de energia como a gasolina, outros derivados de petróleo e do carvão mineral. Também tem contribuído nos últimos anos para o crescimento da produção de canade-açúcar o aumento de demanda por açúcar no mercado mundial e o conseqüente aumento de preços do produto estimulando sua produção.

Segundo dados do Instituto Brasileiro de Geografia e Estatística (IBGE, 2009) e Knight ( 2009) a área plantada de cana de açúcar no Brasil cresceu mais de cinco milhões de hectares desde o ano 2000 alcançando aproximadamente 8,7 milhões de hectares em setembro de 2009. Nos principais estados das regiões centro-oeste, sudeste e sul do Brasil esperam-se um aumento de aproximadamente 15\% sobre a área plantada da safra 2008/2009 sobre a safra 2007/2008 União das Indústrias canavieiras de São Paulo (UNICA, 2009).

As usinas de esmagamento de cana-de-açúcar concentradas principalmente na Região sudeste do Brasil, mais especificamente no Estado de São Paulo, e na região nordeste do país, estas mais antigas ligadas ao histórico secular da produção de monoculturas agrícolas com base exploração da mão-de-obra escrava.

O Brasil é o maior produtor mundial de cana-de-açúcar e o segundo produtor mundial de etanol, sendo assim líder global neste tema. O volume exportado de etanol de cana-deaçúcar pelo Brasil saltou de 750 milhões e litros em 2003 para 3,5 bilhões de litros em 2006, ou seja, $67 \%$ de crescimento anual até então Ministério da Agricultura, Pecuária e Abastecimento (MAPA, 2007).

Deste tema tão em evidência nos últimos tempos, saltam aos olhos aspectos inerentes à sua complexidade: o desalinhamento natural entre interesses e posicionamento das forças e agentes envolvidos, sejam eles dos meios privado ou públicos ou com enfoque econômico, político, social e ambiental. Outro aspecto que chama a atenção é o desbalanceio entre as ações destes vários agentes no tempo e no espaço, por exemplo, as ações empreendedoras do meio privado avançando rapidamente em investimentos buscando posicionamento mercadológico e as ações do meio público nacional buscando salvaguardar interesses nacionais, como o sócio-ambiental. Disto tudo algumas conseqüências surgem e gargalos 
podem afetar o crescimento deste insumo energético e por em risco o posicionamento do Brasil no contexto Global. Alguns exemplos destas conseqüências são: a não formatação e implementação de uma estratégia nacional alinhando os interesses da Nação nos posicionamentos e negociações internacionais, a falta de alinhamento das estratégias para infra-estrutura necessária para o crescimento do Etanol.

Neste aspecto a logística de distribuição do etanol (ao sair das usinas de produção e chegando aos seus destinos físicos finais) tanto para o abastecimento do mercado local quanto do mercado externo. Este último ponto, a logística de distribuição do Etanol é um tema central abordado na pesquisa deste mestrado.

\subsection{Justificativa}

A cultura da cana-de-açúcar como fonte energética renovável nos últimos anos tem sido tema central da agenda política, econômica, social e ambiental no Brasil e no mundo. A cultura da cana-de-açúcar e seus produtos finais do uso humano: Álcool, açúcar, plástico e energia elétrica têm impactado de forma significativa nosso país e mais especificamente as regiões produtoras nas regiões Centro Sul.

Diversos aspectos no que tange à cultura da cana-de-açúcar e mais especificamente ao etanol têm sido trabalhados e discutidos nos últimos anos. Sejam eles sobre impactos da cultura sobre o meio ambiente, a substituição de outras culturas agrícolas com foco alimentar, avanços da cultura em regiões de proteção.

O trabalho aqui proposto é a exploração do que muitos acreditam ser o grande gargalo para a expansão do etanol nos próximos anos no Brasil: a logística. Seja através dos investimentos necessários em infra-estrutura, da avaliação dos modais de transporte, de seus custos associados, nuanças e impactos, a logística do etanol no Brasil é um aspecto que consideramos chave no desenvolvimento desta controversa fonte de crescimento econômicosocial de nosso país.

\subsection{Objetivos}

\subsubsection{Geral}

O principal objetivo da presente dissertação de mestrado é estabelecer cenários para os próximos anos para a expansão do etanol a base de cana de açúcar no Brasil, considerando a 
influência dos agentes envolvidos e os conseqüentes impactos, necessidades e alternativas futuras na logística de distribuição deste insumo energético no Brasil.

\subsubsection{Específicos}

- Estudar a situação atual da demanda, produção e distribuição do álcool etílico de cana de açúcar e outros produtos co-gerados e concorrentes no Brasil e no mundo.

- Avaliar a situação atual da infra-estrutura atual da logística do etanol no Brasil seja nos modais rodoviário, ferroviário, hidroviário ou dutoviário.

- Desenvolver modelagem conceitual de como os condicionantes envolvidos na temática do Etanol no Brasil (agentes econômicos, tecnológicos, sócio - ambientais, políticos ) interage entre si e impactam positivamente e negativamente na demanda de etanol brasileiro.

- Gerar cenários a partir da modelagem tomando como base premissas para os condicionantes de crescimento da demanda e, tendo como resultados, os cenários de crescimento de demanda do etanol brasileiro e os conseqüentes impactos nas necessidades de infra-estrutura logística do etanol no Brasil.

\subsection{Metodologia de Pesquisa}

O presente trabalho apresenta como metodologia de pesquisa a geração de cenários futuros da demanda do etanol brasileiro e as análises dos impactos na logística de distribuição do mesmo. A partir de pesquisa bibliográfica, entrevistas e pesquisas de campo, foram levantadas informações e percepções sobre o histórico do etanol no Brasil e no mundo e, principalmente, o entendimento dos condicionantes da demanda do etanol brasileiro. Em seguida foi desenvolvida a modelagem de causa e efeito entre estes condicionantes para a estruturação de cenários.

Foram desenvolvidos dois cenários: Realista e Otimista. Sendo o cenário realista bastante alinhado com outros cenários desenvolvidos na pesquisa bibliográfica. O cenário otimista, por sua vez, procurou marginalmente avaliar situações mais agressivas enquanto demanda do etanol nos vários condicionantes ligados à sua expansão. Por fim foi realizada a análises dos resultados realçando particularmente os impactos na logística de distribuição do etanol nestes dois cenários. 


\subsection{Estrutura do Trabalho}

O primeiro capítulo do presente trabalho contextualiza e mostra os objetivos do mesmo.

O segundo capítulo explora aspectos da produção do etanol ( características históricas e técnicas do cultivo, produtores e produtos da cana-de-açúcar), os principais mercados consumidores de etanol brasileiro ( mercado interno brasileiro e mercados para exportação), características da logística de distribuição do etanol no Brasil .

O terceiro capítulo desenvolve a modelagem e geração de cenários da demanda de etanol brasileiro e as implicações na oferta e logística de distribuição. Cabe salientar que para a construção de cenários, fez-se necessário a análise dos principais condicionantes para a expansão da demanda do etanol brasileiro.

O quarto capítulo avalia as conclusões finais do estudo, suas implicações e relevância para o futuro do setor sucroalcooleiro.

O quinto capítulo versa considerações finais e as oportunidades surgidas de estudos adicionais ao presente trabalho.

O sexto capítulo apresenta as referências tomadas como base para o presente trabalho. 


\section{PESQUISA BIBLIOGRÁFICA E DE CAMPO}

\subsection{Produção da cana-de-açúcar e derivados}

\subsubsection{Cana-de-açúcar}

A cana-de-açúcar é uma gramínea originária da Índia conforme a figura 1, que produz com maior produtividade entre os paralelos $35^{\circ}$ norte e sul do mundo, trazida ao Brasil por Martim Afonso de Souza em 1532 e desde então passou a ser de enorme importância para o país. Inicialmente sua produção era concentrada na Zona da Mata Nordestina, mas logo se expandiu para região Sudeste, mais precisamente para o Estado de São Paulo . MAPA(2007).

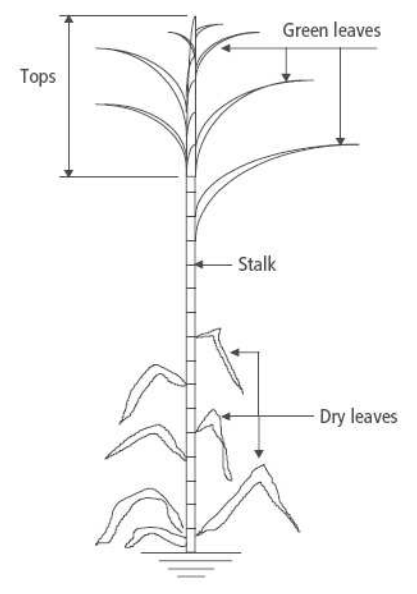

Figura 1 - Cana-de-açúcar

Fonte: Adaptação MAPA, 2007.

O Brasil é o maior produtor mundial de cana-de-açúcar correspondendo a aproximadamente $33 \%$ da produção mundial de cana de 1.558 milhões de toneladas em 2007. A Índia é o segundo produtor mundial com $23 \%$ da produção global no mesmo período conforme ilustra a Tabela 1.

Tabela 1 - produção mundial de cana-de-açúcar até 2007 ( milhões toneladas)

\begin{tabular}{|c|c|c|c|c|c|c|c|c|c|c|c|c|c|c|c|c|c|c|c|c|c|}
\hline & 1990 & 1991 & 1992 & 1993 & 1994 & 1995 & 1996 & 1997 & 1998 & 1999 & $\mathbf{2 0 0 0}$ & $\mathbf{2 0 0 1}$ & $\mathbf{2 0 0 2}$ & $\mathbf{2 0 0 3}$ & $\mathbf{2 0 0 4}$ & $\mathbf{2 0 0 5}$ & $\mathbf{2 0 0 6}$ & $\mathbf{2 0 0 7}$ \\
\hline Brasil & 263 & 261 & 271 & 245 & 292 & 304 & 317 & 332 & 345 & 334 & 328 & 346 & 364 & 396 & 415 & 423 & 457 & 514 \\
\hline Índia & 226 & 241 & 254 & 228 & 230 & 276 & 281 & 278 & 262 & 296 & 299 & 296 & 297 & 287 & 234 & 237 & 281 & 356 \\
\hline China & 63 & 73 & 79 & 69 & 66 & 70 & 71 & 83 & 87 & 78 & 69 & 78 & 92 & 92 & 91 & 88 & 100 & 106 \\
\hline Tailandia & 34 & 41 & 47 & 40 & 38 & 51 & 58 & 56 & 47 & 50 & 54 & 50 & 60 & 74 & 65 & 50 & 48 & 64 \\
\hline México & 40 & 38 & 42 & 43 & 41 & 44 & 45 & 45 & 49 & 47 & 44 & 47 & 46 & 47 & 49 & 52 & 51 & 51 \\
\hline MUND0 & 1.053 & 1.089 & 1.116 & 1.031 & 1.090 & 1.172 & 1.223 & 1.252 & 1.258 & 1.267 & 1.253 & 1.261 & 1.331 & 1.376 & 1.336 & 1.317 & 1.389 & 1.558 \\
\hline
\end{tabular}

Fonte : MAPA,2009. 
Estes dois países que juntos representam mais de 55\% da produção global de cana-deaçúcar em 2007 e apresentam, por outro lado, perfil díspar com relação aos objetivos do cultivo deste insumo agrícola. No Brasil o uso da cana-de-açúcar é variado incluindo o uso como combustível veicular (etanol e biodiesel), alimentação ( açúcar ), gerador de energia elétrica ( bagaço) e matéria-prima para plásticos atendendo tanto o mercado interno quanto o mercado externo.

Já no caso da Índia o uso final é essencialmente para alimentação ( açúcar) da população local, sendo inclusive, sua produção local insuficiente para abastecer o mercado local e recursivamente importando açúcar de outros países, particularmente o Brasil.

Nos últimos anos houve crescimento substancial da produção de cana-de-açúcar no Brasil passando de 427 milhões de ton. em 2006 conforme MAPA (2007), ilustrada na tabela 2, para estimativamente 690milhões de toneladas em 2009 conforme IBGE (Set 2009) apresentando taxa anual de crescimento composta $17 \%$ no período.

Tabela 2 - cana-de-açúcar moída no Brasil ( milhões de toneladas)

\begin{tabular}{c|c|c|c}
\hline \multirow{2}{*}{ SAFRA } & \multicolumn{3}{|c}{ Cana Moida (t) } \\
\cline { 2 - 4 } & Própria & Fornecedores & TOTAL \\
\hline $1991 / 92$ & $137.533 .345,80$ & $91.688 .897,20$ & $229.222 .243,00$ \\
\hline $1992 / 93$ & $134.075 .919,60$ & $89.383 .946,40$ & $223.459 .866,00$ \\
\hline $1993 / 94$ & $123.921 .309,60$ & $82.614 .206,40$ & $206.535 .516,00$ \\
\hline $1994 / 95$ & $144.520 .674,60$ & $96.347 .116,40$ & $240.867 .791,00$ \\
\hline $1995 / 96$ & $144.697 .685,05$ & $105.178 .889,95$ & $249.876 .575,00$ \\
\hline $1996 / 97$ & $200.140 .177,76$ & $89.380 .344,24$ & $289.520 .522,00$ \\
\hline $1997 / 98$ & $206.717 .826,55$ & $95.480 .689,45$ & $302.198 .516,00$ \\
\hline $1998 / 99$ & $215.444 .886,96$ & $100.195 .910,04$ & $315.640 .797,00$ \\
\hline $1999 / 00$ & $211.352 .494,00$ & $98.770 .290,00$ & $310.122 .784,00$ \\
\hline $2000 / 01$ & $173.559 .725,54$ & $81.361 .995,46$ & $254.921 .721,00$ \\
\hline $2001 / 02$ & $191.936 .935,21$ & $100.392 .205,79$ & $292.329 .141,00$ \\
\hline $2002 / 03$ & $200.894 .322,10$ & $115.227 .427,90$ & $316.121 .750,00$ \\
\hline $2003 / 04$ & $228.428 .646,00$ & $128.682 .237,00$ & $357.110 .883,00$ \\
\hline $2004 / 05$ & $230.724 .931,00$ & $150.722 .171,00$ & $381.447 .102,00$ \\
\hline $2006 / 06$ & $232.462 .389,00$ & $150.019 .613,00$ & $382.482 .002,00$ \\
\hline & $259.736 .821,00$ & $167.783 .473,00$ & $427.520 .294,00$ \\
\hline
\end{tabular}

Fonte: MAPA, 2007

Cabe ao estado de SP aproximadamente a $63 \%$ do total de cana-de-açúcar plantado no país, ou aproximadamente, dois terços da produção nacional, conforme tabela 3. 
Tabela 3 - produção de cana de açúcar no Brasil na safra 2005/2006

SAFRA: $05 / 06$

\begin{tabular}{|c|c|c|c|c|c|c|c|c|}
\hline \multirow{2}{*}{ Regiăo } & \multirow{2}{*}{ Estados } & \multicolumn{3}{|c|}{ Cana Moida (t) } & \multicolumn{3}{|c|}{ Álcool $\left(\mathrm{m}^{2}\right)$} & \multirow{2}{*}{$\begin{array}{c}\text { Açúcar (t) } \\
\text { TOTAL. }\end{array}$} \\
\hline & & Própria & Fornecedores & TOTAL & anidro & hidratado & TOTAL & \\
\hline \multirow{11}{*}{ 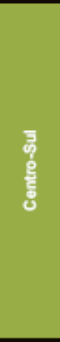 } & ESPIRITO SANTO & $961.082,00$ & $2.375,464,00$ & $3.336 .546,00$ & $159.962,00$ & $41.071,00$ & $201.033,00$ & $48.260,00$ \\
\hline & GOLÁs & $12.706 .198,00$ & $1.861 .809,00$ & $14.568 .007,00$ & $369.279,00$ & $360.779,00$ & $730.058,00$ & $749.839,00$ \\
\hline & MATO GROSSO & $8.916 .753,00$ & $3.426 .176,00$ & $12.342 .929,00$ & $295.718,00$ & $475.321,00$ & $771.039,00$ & $515.087,00$ \\
\hline & MATO GROSSO DO SUL & $4.052 .169,00$ & $4.985 .747,00$ & $9.037 .916,00$ & $184.340,00$ & $311.251,00$ & $495.591,00$ & $400.857,00$ \\
\hline & MINAS GERAIS & $14.881 .151,00$ & $9.443 .387,00$ & $24.324 .538,00$ & $397.135,00$ & $549.707,00$ & $946.842,00$ & $1.732 .946,00$ \\
\hline & PARANÁ & $20.989 .876,00$ & $3.532 .897,00$ & $24.522 .773,00$ & $346.610,00$ & $674,169,00$ & $1.020 .779,00$ & $1.483 .136,00$ \\
\hline & RIO DE JANEIRO & $1.563 .128,00$ & $3.160 .256,00$ & $4.723 .384,00$ & 44.948,00 & $83.276,00$ & $128.224,00$ & $287.733,00$ \\
\hline & RIO GRANDE DO SUL & - & $57.976,00$ & $57.976,00$ & - & $3.338,00$ & $3.338,00$ & - \\
\hline & SANTA CATARINA & - & - & - & - & - & - & - \\
\hline & SÃo PAULO & $138.548 .437,00$ & $102.674 .137,00$ & $241.222 .574,00$ & $5.073 .929,00$ & $4.928 .012,00$ & $10.001 .941,00$ & 17. $188.644,00$ \\
\hline & Subtotal & $202.618 .794,00$ & $131.517 .849,00$ & $334,136,643,00$ & $6.871 .921,00$ & $7.426,924,00$ & $14,298,845,00$ & $22,406,502,00$ \\
\hline \multirow{13}{*}{ 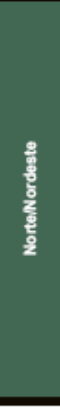 } & ALAGOAS & $15.166 .742,00$ & $7.087,453,00$ & $22.254 .195,00$ & $212,334,00$ & $334,112,00$ & $546,446,00$ & $2.079 .812,00$ \\
\hline & AMAZONAS & $252.672,00$ & - & $252.672,00$ & - & $6.009,00$ & $6.009,00$ & $14.151,00$ \\
\hline & BAHIA & $2.120 .399,00$ & $271.016,00$ & $2.391 .415,00$ & 84. 147,00 & $19.128,00$ & $103.275,00$ & $117.485,00$ \\
\hline & CEARÁ & $12.906,00$ & $27,803,00$ & $40.709,00$ & $\cdot$ & $1.022,00$ & $1.022,00$ & 2076,00 \\
\hline & MARANHĀOO & $310.568,00$ & $533.888,00$ & $844,456,00$ & $42.335,00$ & $13.808,00$ & $56.143,00$ & $11.618,00$ \\
\hline & PARÁ & $502.316,00$ & - & $502.316,00$ & $33.982,00$ & $8.193,00$ & $42.175,00$ & - \\
\hline & PARAIBA & $1.229 .579,00$ & $2.979 .164,00$ & 4.208.743,00 & $111.51,00$ & $156.077,00$ & $267.648,00$ & $115.573,00$ \\
\hline & PERNAMBUCO & $8.016 .424,00$ & $5.781,426,00$ & $13.797 .850,00$ & $206.110,00$ & $119.469,00$ & $325.579,00$ & $1.226 .763,00$ \\
\hline & Plauí & $437.962,00$ & $54,407,00$ & $492.369,00$ & $26.597,00$ & $8.486,00$ & $35.083,00$ & 7,00 \\
\hline & RIO GRANDE NORTE & $853.506,00$ & $1.502 .762,00$ & $2.356 .268,00$ & $50.811,00$ & $22,959,00$ & $73.770,00$ & $175.340,00$ \\
\hline & SERGIPE & $845.207,00$ & $263,845,00$ & $1.109 .052,00$ & $19.329,00$ & $28.642,00$ & $47.971,00$ & $65.064,00$ \\
\hline & TOCANTINS & $95.314,00$ & - & $95.314,00$ & 4. 108,00 & 110,00 & $4.218,00$ & - \\
\hline & Subtotal & 29.843.595,00 & $18.501 .764,00$ & $48.345,359,00$ & $791.324,00$ & $718.015,00$ & $1.509 .339,00$ & $3.807 .889,00$ \\
\hline & TOTAL & $232.462 .389,00$ & $150.019 .613,00$ & $382,482.002,00$ & $7.663 .245,00$ & 8.144.939,00 & $15.808 .184,00$ & $26.214 .391,00$ \\
\hline
\end{tabular}

Fonte MAPA, 2006

Aproximadamente $60 \%$ das usinas de processamento de cana-de-açúcar no Brasil estando elas espalhadas principalmente pelo estado de São Paulo e estados da região Nordeste conforme ilustra a figura 2.

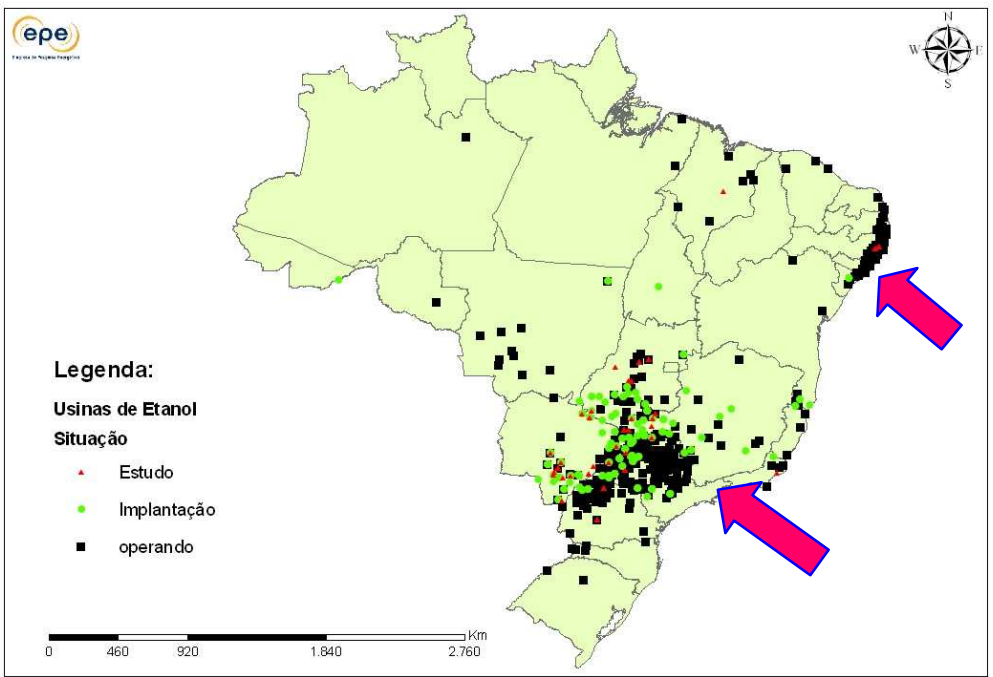

Figura 2 - Distribuição de usinas de cana-de açúcar no Brasil

Fonte : EPE,2008

A destinação da cana-de-açúcar para a produção do açúcar e do álcool sempre foram bem diferente. Antes se destinava a maior parte da cana para produzir o açúcar, mas com o 
passar dos anos, a produção do álcool começou a crescer muito, então a destinação da cana passou a ser praticamente $50 \%$ para a produção do açúcar, e 50\% para a produção do álcool.

A Figura 3 mostra a distribuição do ATR ( Açúcar Total Recuperável) por produto final: açúcar e álcool.

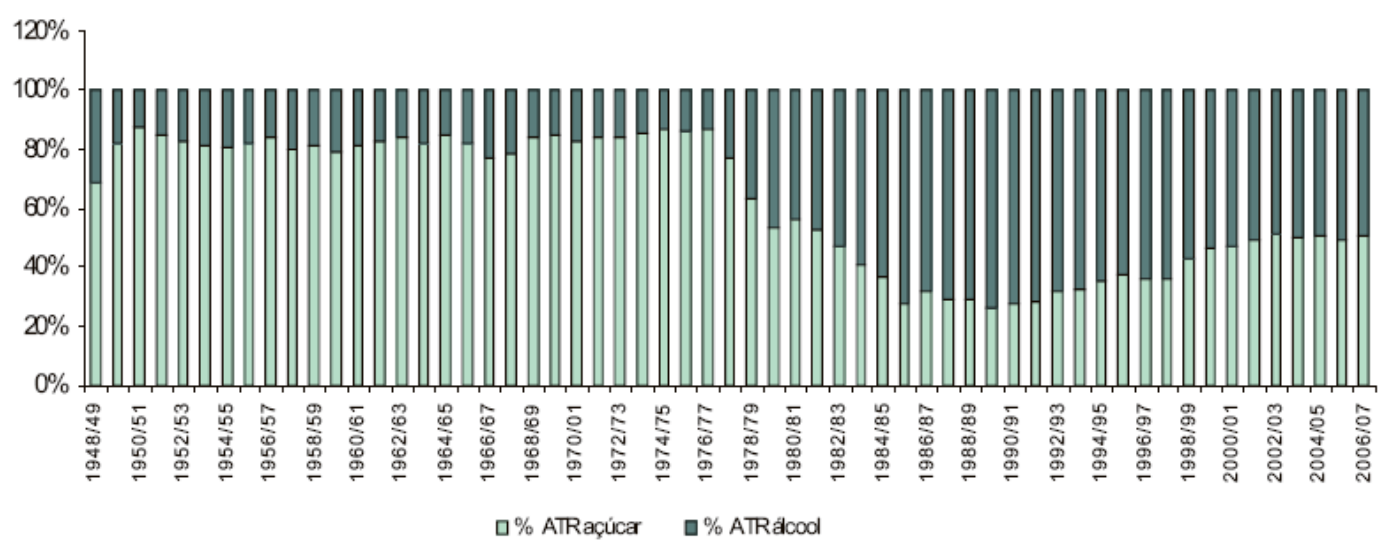

Figura 3 - Distribuição da produção entre açúcar e álcool no Brasil

Fonte: MAPA, 2007

\subsubsection{Etanol}

O Brasil historicamente foi o maior produtor mundial de etanol, mas a partir de 2005, os EUA tomaram a liderança na produção mundial. A tabela 4 mostra os principais países produtores de álcool. 
Tabela 4 - Principais países produtores de etanol

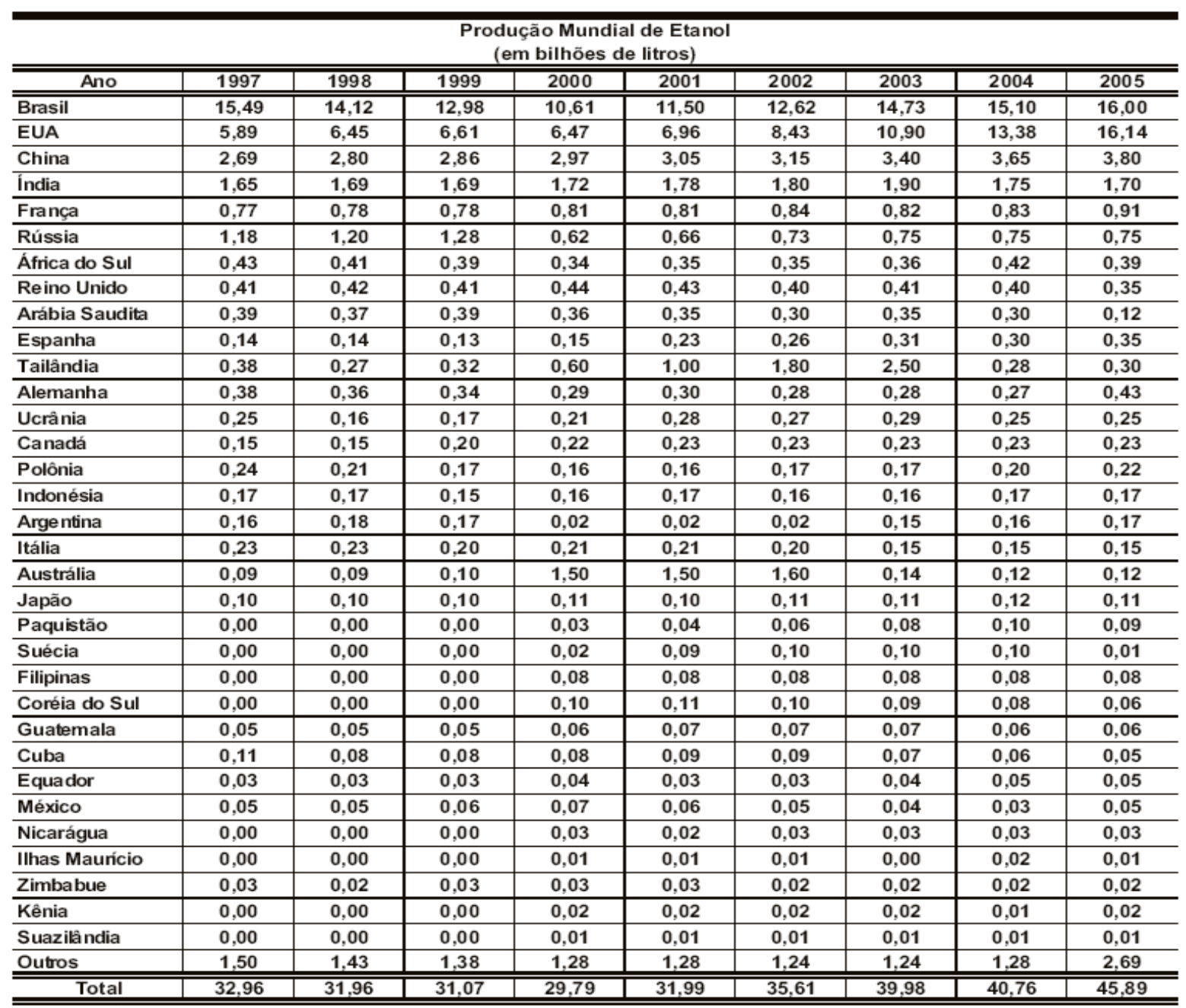

Fonte: MAPA, 2007 apud F.O. Licht'S, 2006

A produção de álcool oriundo da cana-de-açúcar ( etanol) cresceu substancialmente a partir do final dos anos 70 por conta do programa de incentivo ao álcool ( Proálcool), programa este de incentivo á produção e substituição da gasolina para fins combustíveis por etanol. 
A figura 4 ilustra esta evolução.

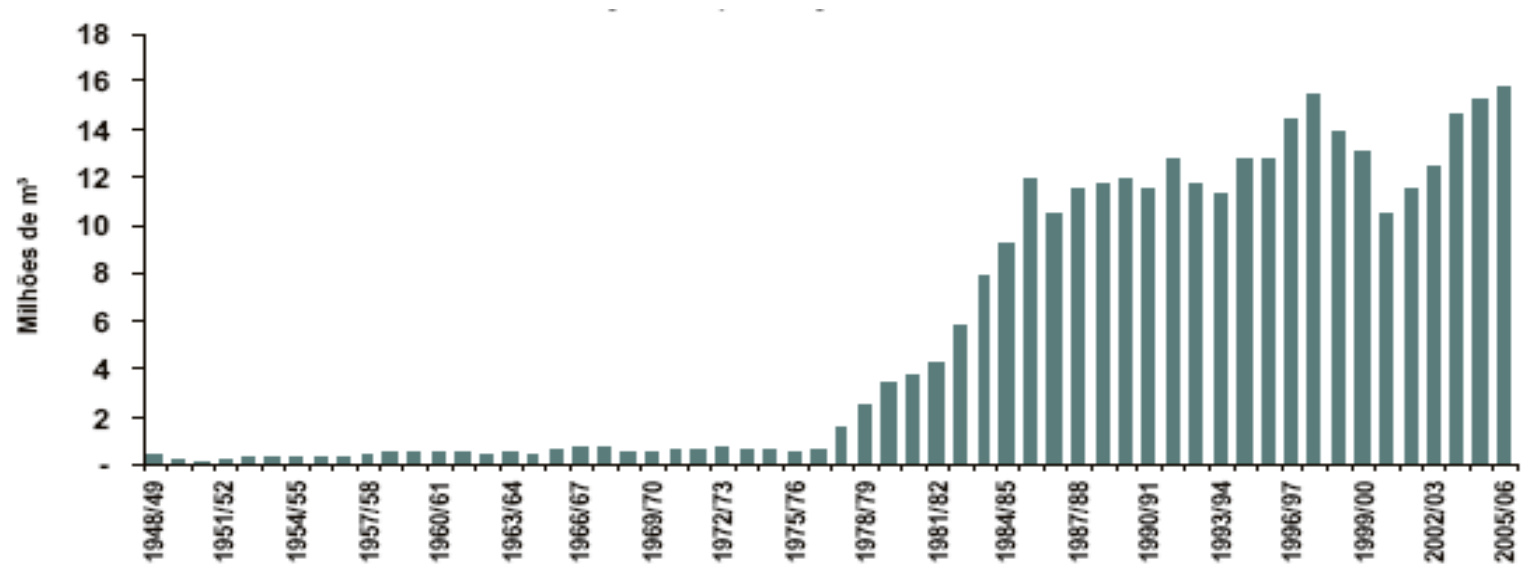

Figura 4 - Evolução da produção de etanol no Brasil

Fonte: MAPA, 2007

Nos anos 90, com o fim do programa e a estabilização e redução do preço internacional do petróleo, houve a estabilização da produção do álcool e mesmo sua queda em alguns momentos. A partir dos anos 2000 com a nova elevação do preço internacional do petróleo, as metas de controle e redução de emissões dos gases de efeito estufa, novamente houve um incremento da produção desta fonte renovável e limpa. Elevaram as exportações brasileiras de álcool de cana a uma taxa de $51 \%$ ao ano entre 2002 e 2006, conforme mostra a figura 5 a seguir.

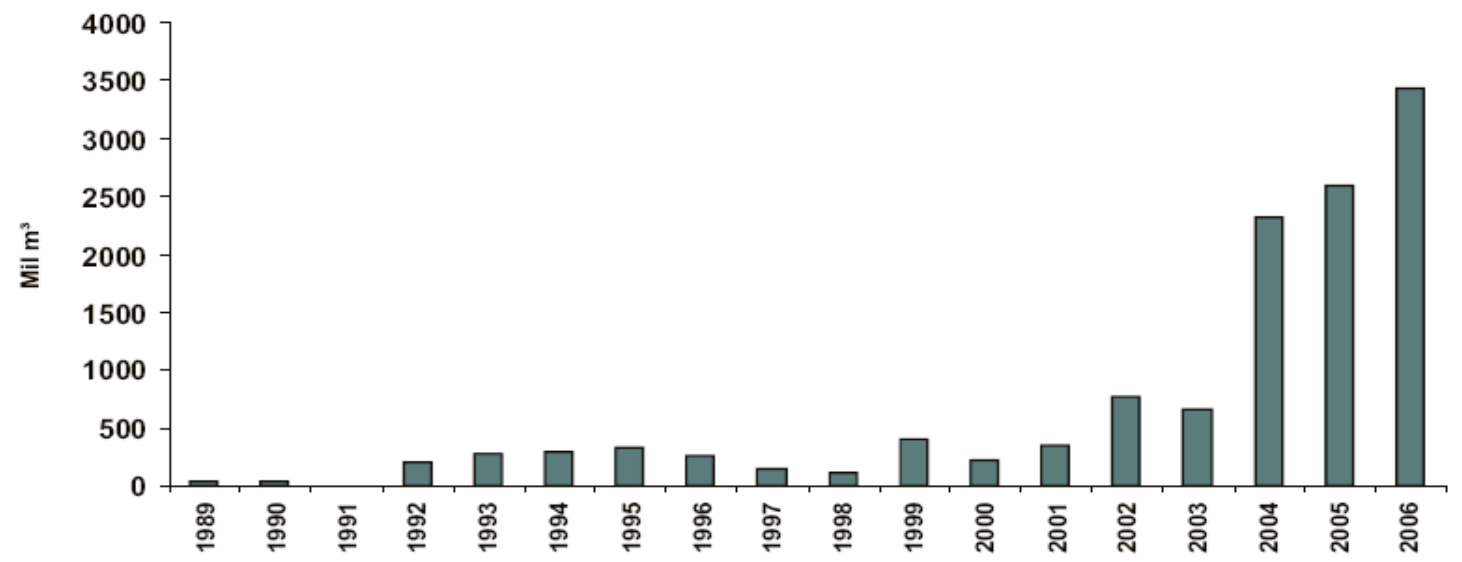

Figura 5 - Evolução, em volume, das exportações brasileiras de álcool 
2.1.1.2. Açúcar e outros derivados

Ao mesmo tempo, houve incremento significativo na produção do açúcar de cana-deaçúcar conforme mostra a figura 6 , por conta tanto do incremento do consumo interno quanto pelas exportações devido à elevação de preços do açúcar no mercado internacional.

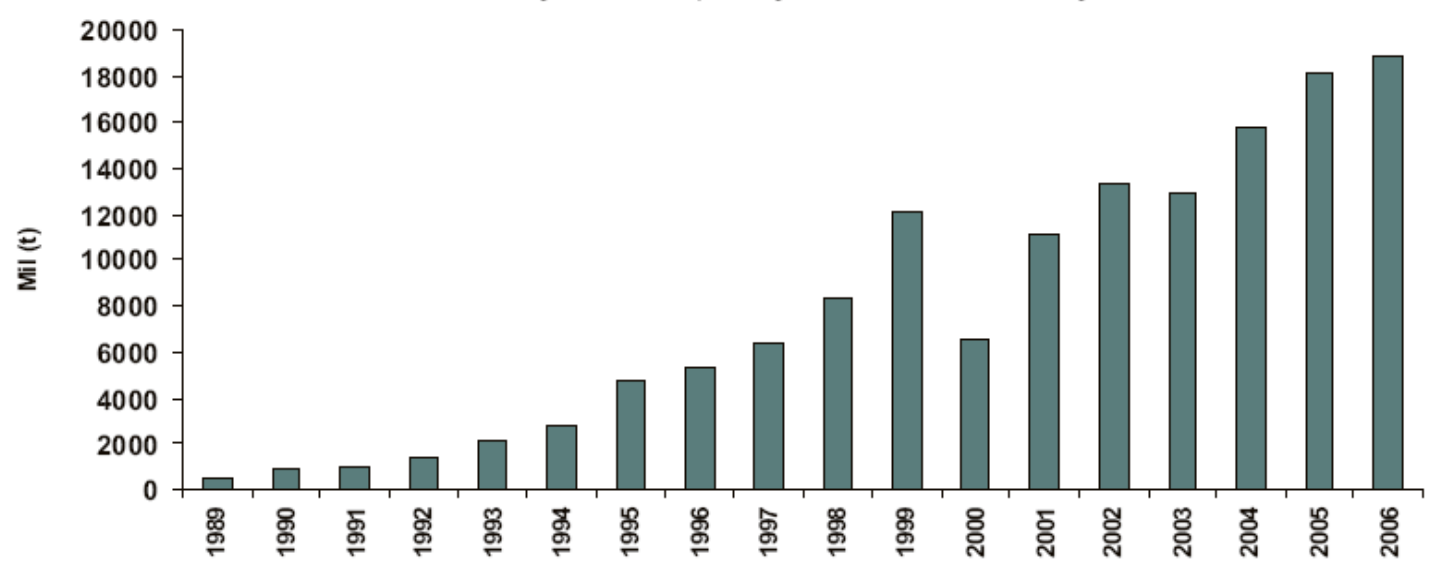

Figura 6 - Produção Brasileira de Açúcar

Fonte: Mapa, 2007

O Brasil também é o maior produtor do açúcar no mundo tendo tido taxa de crescimento de $5,6 \%$ ao ano no período de 2000 a 2005 e representando aproximadamente $20 \%$ da produção mundial de açúcar em 2005. A União Européia, região que concentra a segunda maior produção mundial, no mesmo período representou aproximadamente $15 \%$ da produção mundial. A tabela 5 ilustra esta evolução.

Tabela 5 - Maiores países produtores de açúcar

\begin{tabular}{l|c|c|c|c|c|c|c|c|c}
\hline $\begin{array}{c}\text { PRODUÇAO } \\
\text { Em 1.000 Toneladas }\end{array}$ & 1998 & 1999 & 2000 & 2001 & 2002 & 2003 & 2004 & 2005 \\
\hline Brasil & 19.168 & 20.646 & 16.464 & 20.336 & 23.567 & 25.956 & 26.377 & 28.134 \\
\hline União Européia & 17.398 & 18.731 & 17.854 & 15.500 & 18.241 & 16.578 & 21.845 & 21.697 \\
\hline India & 14.281 & 17.406 & 20.247 & 19.906 & 19.524 & 21.701 & 14.432 & 15.215 \\
\hline China & 8.904 & 8.527 & 7.616 & 7.161 & 9.804 & 11.433 & 10.912 & 9.785 \\
\hline Es tados Unidos & 7.159 & 8.243 & 8.080 & 7.774 & 6.804 & 7.963 & 7.647 & 6.783 \\
\hline México & 5.287 & 5.030 & 4.816 & 5.614 & 5.073 & 5.441 & 5.671 & 5.619 \\
\hline Austrália & 5.085 & 5.514 & 4.417 & 4.768 & 5.613 & 5.315 & 5.530 & 5.393 \\
\hline Tailândia & 4.143 & 5.456 & 6.157 & 5.370 & 6.437 & 7.737 & 7.462 & 4.588 \\
\hline Paquistão & 3.503 & 3.709 & 2.053 & 2.720 & 3.334 & 4.063 & 4.480 & 2.838 \\
\hline Cuba & 3.291 & 3.875 & 4.057 & 3.748 & 3.521 & 2.277 & 2.600 & 1.300 \\
\hline Outros Paises & 42.490 & 39.284 & 38.811 & 37.719 & 40.108 & 39.897 & 41.311 & 39.962 \\
\hline \multicolumn{1}{c|}{ TOTAL } & 130.709 & 136.420 & 130.574 & 130.616 & 142.026 & 148.361 & 148.267 & 141.314 \\
\hline
\end{tabular}

Fonte: MAPA, 2007 
2.1.1.2.1. Bagaço da cana-de-açúcar

O bagaço da cana de açúcar é o resíduo da produção de açúcar e álcool destinado basicamente à geração de energia nas formas térmica e elétrica. Essa energia é capaz de suprir toda a demanda das unidades produtoras e ainda gerar excedentes exportáveis à rede de elétrica. Sua produção ao longo do tempo cresce proporcionalmente ao crescimento do esmagamento da cana de açúcar. De 1990 a 2005, conforme a tabela 6, a produção de bagaço de cana cresceu $4,5 \%$ ao ano.

Tabela 6 - Produção brasileira de bagaço, caldo e melaço de cana-de-açúcar.

\begin{tabular}{c|c|c|c}
\hline \multirow{2}{*}{ Ano } & \multicolumn{3}{|c}{ Produção em milhões de (t) } \\
\cline { 2 - 4 } & Bagaço & Caldo* & Melaço $^{*}$ \\
\hline \hline 1990 & 54.776 & 99.776 & 4.480 \\
\hline 1991 & 58.801 & 112.673 & 4.544 \\
\hline 1992 & 62.002 & 99.358 & 5.032 \\
\hline 1993 & 60.584 & 94.029 & 4.696 \\
\hline 1994 & 70.543 & 98.986 & 5.866 \\
\hline 1995 & 69.847 & 95.510 & 6.561 \\
\hline 1996 & 73.632 & 105.627 & 7.709 \\
\hline 1997 & 82.039 & 118.285 & 7.689 \\
\hline 1998 & 82.183 & 101.921 & 8.573 \\
\hline 1999 & 82.487 & 88.171 & 9.275 \\
\hline 2000 & 66.309 & 73.030 & 7.245 \\
\hline 2001 & 78.040 & 72.919 & 9.026 \\
\hline 2002 & 87.233 & 76.974 & 10.295 \\
\hline 2004 & 97.321 & 89.149 & 11.215 \\
\hline 2005 & 101.795 & 92.024 & 11.779 \\
\hline
\end{tabular}

Fonte: MAPA, 2007 


\subsubsection{Produtores de etanol}

Os produtores de etanol, assim como os de açúcar, no Brasil são compostos por empresas privadas. Desde o início da plantação e processamento nas usinas na região nordeste brasileira até as atuais e modernas usinas no sudeste e centro oeste brasileiro, os produtores tem se caracterizado por empresas competitivas entre si e muitas com o comando familiar. As usinas proliferaram à medida que as oportunidades econômicas permitiram a implantação de novos empreendimentos ao longo dos vários séculos desta cultura agrária no Brasil. Assim, o mercado produtor brasileiro se formou e ainda é extremamente fragmentado em termos de participação de mercado. Esforços de consolidação e união começaram a tomar corpo com a formação da Coopersucar, conforma a mesma, cooperativa que foi formada nos anos 50 para promover a comercialização de suas 10 empresas fundadoras. Conforme Knight ( 2009), a Coopersucar cresceu rapidamente e já nos anos 70, quase 100 usinas no estado de São Paulo estavam associadas à cooperativa. Ao longo dos anos a Coopersucar diversificou sua atuação, café, por exemplo, e criou a mais conhecida marca de açúcar no varejo brasileiro: União.

Outro ator importante no setor produtivo sucroalcooleiro no Brasil no século 20 é o IAA ( Instituto do Açúcar e Álcool ). Criado em 1929 pelo governo de Getúlio Vargas após o crash da bolsa de Nova Iorque, o IAA tinha o objetivo de estabelecer cotas de produção, critérios rígidos na cadeia produtiva e na comercialização interna e externa dos derivados da cana. A Copersucar e IAA caminharam durante décadas juntas. Desta forma, apesar de fragmentado o mercado de etanol ( e açúcar) foi regido de forma controlada, de certa forma, centralizada.

Após as crises mundiais do Petróleo na década de 1970, com a criação pelo governo federal brasileiro do Proálcool e a substituição da gasolina por etanol hidratado da cana-deaçúcar como combustível de automóveis, surgiram oportunidades substanciais de comercialização de etanol. Desta forma, conforme Knight (2009), dezenas de novas usinas foram criadas, oriundas de grupos familiares tradicionais e novos entrantes no mercado. Porém as oportunidades duraram poucos anos.

$\mathrm{Na}$ década de 80 os preços do petróleo no mercado internacional reduziram dramaticamente onerando demasiadamente os cofres públicos brasileiros pelo subsídio ao preço do álcool de cana. Ações foram criadas para contrabalancear a queda no consumo de etanol hidratado como a adição de 20 a 25 percentuais de etanol anidro à gasolina e a redução tarifária do etanol em comparação à gasolina. De qualquer forma, o cenário como um todo 
deflagrou o final do Proálcool e a desestruturação da cadeia produtiva da cana no Brasil nos anos 80. Os usineiros buscaram soluções como a transformação ou criação de linha de produção de açúcar, em detrimento da especialização de usinas na produção de etanol. Os usineiros também procuraram mecanismos para exportação direta do açúcar sem passar pelo IAA, iniciativa esta, conforme o Knight ( 2009), capitaneada pela tradicional família paulista Ometto , acionista majoritária da Cosan, maior empresa do setor atualmente. Em 1989 o IAA foi encerrado. Estas ações das usinas a partir do final dos anos 80 descentralizaram o setor, muitas usinas passaram a exportar diretamente e novas pequenas cooperativas foram criadas como a Crystalsev.

Neste período começaram a entrar empresas estrangeiras no setor sucroalcoleiro brasileiro. Conforme Knight (2009), o primeiro grupo econômico estrangeiro a atuar no Brasil foi o grupo francês Béghin-Say, renomeado Tereos, que adquiriu o controle do grupo local Guaraní. Posteriormente grandes grupos econômicos como Louis Dreyfus, Cargill e Bunge iniciaram suas atividades no Brasil.

A partir dos anos 2000, com a nova crise do petróleo, a crescente preocupação com a extinção desta fonte energética e a sua característica poluente, o etanol da cana brasileiro voltou à tona como fonte energética, particularmente para transporte.

Nos últimos 4 ou 5 anos da década citada, o Brasil viveu uma explosão de investimentos na expansão e criação de novas usinas de processamento de cana e nos campos de plantação de cana ( Greenfields ). Atraídos pela perspectiva de retornos com o etanol (e também pelo açúcar) centenas de novas usinas foram criadas. Conforme EPE (2008), somente em 2008114 novas usinas estavam em implantação no começo daquele ano.

Em 2008, conforme Jank (2009), presidente da Unica, uma série de fatores sazonais e cíclicos afetaram as usinas de cana do Brasil: por um lado a safra recorde de cana, conforme dados do IBGE(2009), com incremento de 17,4\% sobre o ano anterior e representando 645 milhões de toneladas da cana produzida em 2008 em função dos maciços investimentos nas usinas e greenfields fizeram com que os preços do combustível despencassem . Ao mesmo tempo muitas usinas tiveram significantes problemas financeiros por conta da elevação de custo operacionais ( inflação interna) das usinas bem como pela inexperiência dos novos entrantes no mercado. Desta forma, foi muito comprometido o retorno que os acionistas esperavam. Assim, muitas usinas tiveram dificuldades em honrar seus compromissos e pagamentos inclusive, em muitos casos, entrando em regime de recuperação judicial.

Este contexto acelerou o processo de consolidação do setor, conforme comentado anteriormente, extremamente fragmentado. Os ativos se tornaram baratos em comparação aos 
anos anteriores. A tabela 7 ilustra as principais empresas do setor e dados de produção. $\mathrm{Na}$ seqüencia comenta-se os maiores grupos e usinas de cana de açúcar no Brasil

Tabela 7 - 14 maiores empresas sucroalcooleiras do Brasil na safra 2008/2009

\begin{tabular}{|l|r|r|r|r|}
\hline empresa & $\begin{array}{r}\text { Número de } \\
\text { usinas }\end{array}$ & $\begin{array}{r}\text { Cana processada } \\
(1,000 \text { toneladas })\end{array}$ & $\begin{array}{r}\text { açúcar } \\
\text { produz ido } \\
(1,000 \text { tons })\end{array}$ & $\begin{array}{r}\text { Etanol produzido } \\
\text { (milhões litros) }\end{array}$ \\
\hline Cosan & 22 & $44,212.5$ & $3,276.2$ & $1,721.5$ \\
\hline Santelisa Vale & 6 & $17,599.0$ & $1,035.9$ & 795.4 \\
\hline $\begin{array}{l}\text { Guarani } \\
\text { (Tereos) }\end{array}$ & 6 & $13,800.7$ & $1,094.5$ & 495.9 \\
\hline $\begin{array}{l}\text { Santa- } \\
\text { Terezinha }\end{array}$ & 8 & $13,785.5$ & $1,104.1$ & 650.8 \\
\hline Moema & 7 & $12,695.1$ & 714.1 & 416.0 \\
\hline Carlos Lyra & 7 & $12,180.4$ & 944.4 & 675.9 \\
\hline São Martinho & 4 & $12,000.9$ & 555.4 & 485.8 \\
\hline $\begin{array}{l}\text { Tercio } \\
\text { Wanderley }\end{array}$ & 8 & $11,837.4$ & 844.2 & 568.2 \\
\hline Louis Dreyfus & 9 & $11,182.2$ & 559.5 & 558.7 \\
\hline Zilor & 4 & $10,255.3$ & 534.7 & 568.8 \\
\hline Moreno & 3 & $9,515.1$ & 354.3 & 411.4 \\
\hline $\begin{array}{l}\text { Virgolino de } \\
\text { Oliveira }\end{array}$ & 4 & $9,002.5$ & 560.8 & 586.2 \\
\hline $\begin{array}{l}\text { Pedra } \\
\text { Agroindustrial }\end{array}$ & 4 & $8,865.8$ & 279.9 & 341.0 \\
\hline Nova América & 4 & $8,423.2$ & 593.5 & \\
\hline
\end{tabular}

Fonte: Knight, 2009

Cosan: maior grupo nacional de etanol e açúcar de cana. Segundo a empresa, desde 2005 tem suas ações negociadas no Novo Mercado da Bolsa de Valores de São Paulo ( Bovespa), segmento de ações das empresas com o mais alto grau, conforme critérios da Bovespa, de governança corporativa. Em 2007, teve suas ações listadas na Bolsa de Nova York (NYSE), tornando-se a primeira empresa de controle brasileiro com ativos negociados diretamente na NYSE. Umas das empresas mais agressivas nas aquisições tendo adquirido nos últimos dois anos o grupo Novamerica ( então detentora da marca de açúcar União) . Com a aquisição passa a ter capacidade de aproximadamente 60 milhões de toneladas/ano. Adquiriu também as operações brasileiras da Esso ( do grupo americano Exxon Mobil) na distribuição de combustíveis veiculares. Conforme Knight (2009) a transação de compra inclui 1500 postos de venda de combustível e 50 pontos de distribuição. A compra garantiu ao grupo $7 \%$ de participação no mercado brasileiro de venda de combustíveis. O grupo Cosan tem se mostrado, dentre as usinas do setor, a mais agressiva. A alavancagem para financiar os 
investimentos aparentemente tem pressionado os executivos da empresa por resultados financeiros. Conforme Magossi (2009a), duas novas usinas foram lançadas em Setembro de 2009, Jataí e Caarapó , sendo estas as últimas previstas. Outras novas foram deixadas de lado. Para o orçamento do ano fiscal de 2010 estavam previstos R \$1.4 Bilhão em investimentos, sendo que a maior parte prevista para melhorias e expansão de usinas já existentes. Outras ações têm sido feitas para alongar o perfil da dívida, por exemplo, ainda conforme Magossi (2009a), o perfil da dívida de custo prazo deve cair em 2010 de $24 \%$ para $10 \%$ do total da dívida. Outra característica que tem sido marcante neste grupo em específico, e inserida neste contexto a compra das operações da Esso no Brasil, A Cosan, claramente tem adotada uma estratégia de diversificação concêntrica, conforme Kotler (2000), na medida em que tem diversificado os seus negócios: Etanol, Açúcar, Cogeração de energia, distribuição e comercialização de combustíveis ( incluindo gasolina e diesel) e logística integrada. Com isto busca a diluição de riscos assumindo a gestão de um portfólio de negócios atuantes em mercados diferentes, porém com elementos comuns ( sinergias) processuais entre eles. Conforme acesso a site da empresa Cosan e Knight (2009), a Rumo logística, subsidiária do Grupo Cosan e parceira da ALL - América Latina Logística , empresa do setor de transporte ferroviário, deverá captar investimentos da ordem de $\mathrm{R} \$ 1.2$ Bilhão nos próximos anos para aquisição de novas locomotivas e expansão da malha ferroviária. Com isto irá transportar além do açúcar produzido pelas usinas do grupo Cosan, outros produtos de terceiros nos quais será remunerado pelo frete realizado. Assim em 2013 espera-se que os negócios adjacentes do grupo: logística através da Rumo Logística, cogeração de energia e distribuição e comercialização de combustíveis através da Cosan Combustíveis e Lubrificantes ( CCL), antiga Esso representem 60\% frente aos negócios tradicionais da empresa ( açúcar e álcool) que representarão $40 \%$ da geração de caixa antes de encargos financeiros, impostos e depreciação ( EBITDA).

Louis Dreyfus Commodities (LDC), empresa do grupo francês de mesmo nome e conforme a empresa, uma das 10 maiores empresas exportadoras do Brasil com presença em quase todo o território brasileiro. Faturou em 2008 aproximadamente R $\$ 8$ Bilhões no Brasil com seus negócios nas commodities agrícolas como oleaginosas, suco de laranja, açúcar e álcool.

Conforme Knight (2009), em 2000 LDC comprou a usina Cresciumal no interior do Estado de São Paulo com capacidade de esmagamento de 1.8 milhões de toneladas/ano de cana-deaçúcar. A partir daí passou a incorporar outras empresas do setor. Conforme site da empresa, 
em Outubro de 2009 criou a LDC - SEV, braço de bioenergia do grupo LDC, formado a partir de suas operações em cana-de-açúcar e a compra da Santelisa Vale, até então a segunda maior empresa do setor sucroalcoleiro no Brasil. Conforme Scaramuzzo (2009), a Santelisa Vale liderada pelas famílias Biagi, Junqueira e pelo Banco de investimentos Goldman Sachs sucumbiu aos efeitos da crise mundial de 2008 e vendeu 60\% de seu capital (e dívida) para a LDC. Santelisa Vale havia sido formada dois anos antes a partir da fusão entre as usinas Santelisa e Vale do Rosário. Com isto a LDC-SEV passou a ter capacidade de processamento de 60 milhões de toneladas / ano e se tornou a segunda maior empresa do setor sucroalcooleiro no Brasil e no mundo.

ETH Bioenergia, empresa criada em 2007 pelo grupo brasileiro Odebrecht com participação de 33\% do capital da empresa de comércio japonesa Sojitz, possuirá segundo a empresa capacidade de moagem de 13.2 milhões de toneladas /ano da cana-de-açúcar. Em Outubro de 2009 a ETH assinou acordo com a empresa Brenco, outro novo atuante no setor, para formar a maior empresa sucroalcooleira do mundo. Conforme Magossi (2009b), esta fusão terá capacidade de moagem de até 37 milhões de toneladas/ano de cana-de-açúcar em 2013/2014. A empresa Brenco foi formada por empresários e investidores estrangeiros com a especialização na produção e comercialização de etanol. Sem ter nenhuma unidade produtiva ainda em operação em 2008, sofreu problemas financeiros com a crise global neste mesmo ano.

Tereos- Guarani, empresa do Grupo Francês Tereos que adquiriu o grupo nacional Guarani e diferentemente das grandes empresas do setor, possui vocação quase total para produção de açúcar, em detrimento do etanol, sendo que, conforme Knight (2009), boa parte do açúcar é destinado á exportação. Conforme ainda esta fonte, sofreu com a dependência de moeda estrangeira ( leia-se Dólares Americanos) e foi socorrida financeiramente pela matriz francesa em 2008.

Outros grandes grupos internacionais têm atuado e crescido suas participações no Brasil ainda que em proporção substancialmente menor que as líderes. Conforme Biagi (2009), 25\% do capital das empresas do setor sucroalcooleiro no Brasil está nas mãos de empresas internacionais. A empresa americana Cargill, trader global de commodities agrícolas, conhecida no Brasil principalmente pela atuação na Soja, tem adquirido nos últimos anos participação em usinas locais no estado de São Paulo. O grupo do continente americano 
(americano, argentino, brasileiro), Bunge possui participação em usinas nos estados de Minas Gerais, Tocantins e Mato Grosso do Sul e parceria com a também trade company japonesa Itochu com vistas à exportação de etanol para o Japão. O grupo americano ADM, um dos maiores produtores de etanol nos EUA, tem procurado desenvolver aquisições de usinas com grupos já estabelecidos como Unialco, Da Mata e Cabrera, que não evoluiu. Os grupos mencionados ADM, Cargill e Bunge estavam em negociação para aquisição do grupo Moema, quinto maior nos Estados Unidos da América e adquiriu usinas no Brasil com produção de 5.5milhões de toneladas da cana-de-açúcar em 2008. O grupo petrolífero britânico British Petroleum ( BP) também tem desenvolvido negócios na área sucroalcooleira no Brasil através da aquisição de participação na Companhia Nacional de Açúcar e Álcool e na Tropical Bioenergia , empresa do grupo algodoeiro Maeda e da Santelisa Vale. Com isto a capacidade esperada de esmagamento para 2009 será de 4.8 milhões de toneladas conforme Knight (2009).

A Petrobrás, a maior empresa brasileira, conforme Knight (2009), planeja desenvolver alguns negócios diretamente na produção do etanol, adquirindo participações de empresas e construindo usinas próprias, com isso produzindo em 20134 bilhões de litros de etanol. Conforme Queiroz ( 2007), o papel da Petrobrás no etanol, além de produção de etanol em si, envolve participação em toda a cadeia do negócio sucroalcooleiro:

- Operador Logístico: Tanques, dutos, terminais, navios para a transferência do etanol dos produtores aos mercados,

- Investidor: Construção de centros de coleta de álcool em diversas áreas produtivas e regulador de estoques e fluxo de caixa de produtores,

- Pesquisador: fomentar pesquisa de ponta, como por exemplo o etanol de segunda geração e Biodiesel do etanol

- Distribuidor: Distribuição de etanol veicular através da BR Distribuidora

- Trader: exportador de etanol para diversos países, particularmente EUA .

O plano estratégico corporativo da Petrobrás deixa clara a intenção de atuar fortemente no etanol, dentro do contexto dos biocombustíveis, em todos os elos da cadeia produtiva desde a pesquisa e desenvolvimento até a logística e comercialização do etanol, conforme ilustra a figura 7. 
Pequenas usinas, ou seja, empresas independentes e com capacidade de moagem abaixo de um milhão de toneladas/ano têm se tornado pouco atrativas com respeito à consolidação do setor por conta das grandes empresas. Alternativas viáveis têm passado pela cooperação entre estas usinas e também pela criação de empresas orientadas para a fusão de pequenas usinas.

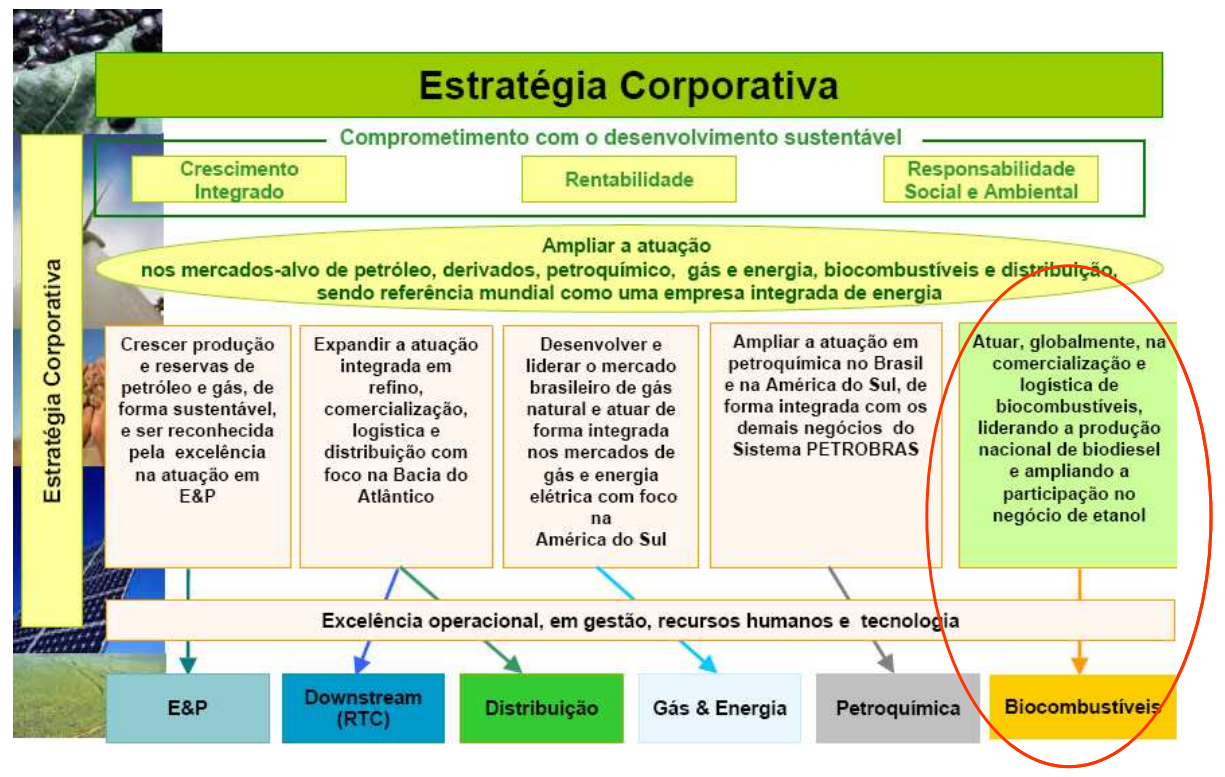

Figura 7 - Plano estratégico corporativo Petrobrás 2008 -2012

Fonte: Mozart , 2007 apud Petrobrás, 2007.

\subsubsection{Características técnicas do cultivo e processamento}

O processo produtivo da cana-de-açúcar, seu processamento e transformação em álcool e/ou açúcar e geração de energia elétrica compreende algumas nuanças. O desenvolvimento de variedades de cana por projetos principalmente desenvolvidos pela Embrapa tem elevado substancialmente a produtividade dos canaviais brasileiros. Existem canaviais de alta produtividade ( acima de 100 ton./ha-ano) da cana-de-açúcar mas uma média no Brasil gira em torno de 80 a 90 ton./ha-ano.

Têm sido desenvolvidas ainda variedades resistentes a diferentes tipos de praga, mas ainda não se chegou a alguma resistente à maioria das pragas. Assim, é prática comum nos canaviais, plantar-se diferentes variedades de cana, mesmo com níveis diferentes de produtividade por ha, para minimizar riscos de perda de safra. 
Aspecto interessante é a necessidade intensiva de água (além de energia solar). Assim, as safras de cana são totalmente dependentes do regime de chuva, que na região sudeste do Brasil ocorre nos meses de verão. Desta forma, as colheitas da cana (e seu consecutivo processamento) são realizadas nos períodos de seca. Outro aspecto que influencia nesta característica sazonal de produção de cana e processamento é que durante as chuvas uma possível colheita seria bem pouco produtiva manualmente ou mecanicamente, dadas as condições inóspitas ( barrentas ) dos canaviais para a colheita.

Durante o período de chuvas, ou seja, sem processamento da cana, as usinas normalmente passam por processos longos e pesados de manutenção nos equipamentos e máquinas uma vez que o processamento da cana é bastante rude e desgastante para as máquinas.

As usinas de processamento devem sempre estar muito próximas das fontes de fornecimento de cana ( os canaviais), no máximo a $50 \mathrm{~km}$ de distância. A razão para isso é o incremento significativo do custo logístico no custo total do etanol ou açúcar em função da distância dos canaviais às usinas. Outro fator fundamental é que, após ter sido cortada, sendo cessado o ciclo vital da planta, o processo de degradação química da mesma é extremamente acelerado. Ao final o que se quer da cana é o açúcar contido em sua estrutura e após ser cortada e sujeita a altas temperaturas ambientes sua degradação é exponencial. Desta forma, os caminhões com cana ao darem entrada nas usinas, são pesadas na balança e o teor de açúcar (brix ) avaliado. O valor pago pela cana in-natura, quando comprado, depende deste indicador.

A seguir a cana é lavada, cortada e enviada para a moagem. Moída a cana, gera-se o caldo, essencialmente água, Açúcar e outros componentes. A partir daí pode-se direcionar o processo para a produção de açúcar ou para a fermentação e posterior destilação gerando o álcool. Deste processo gera-se a vinhaça, que pode ser utilizado como fertilizante dos canaviais. Estudos mais recentes propõem a utilização da vinhaça em processos de co-geração de energia.

O resíduo da moagem, o bagaço de cana, pode ter duas diferentes destinações: venda do bagaço de cana para outras empresas utilizarem como combustível de caldeiras ou a geração de energia elétrica (para uso interno da usina ou venda à rede ) a partir da queima do bagaço . A venda deste excedente de energia elétrica para a rede tem tido muitas dificuldades, uma delas é por se tratar de uma energia não firme. A figura 8 ilustra esquematicamente o processo produtivo de uma usina de cana-de-açúcar 


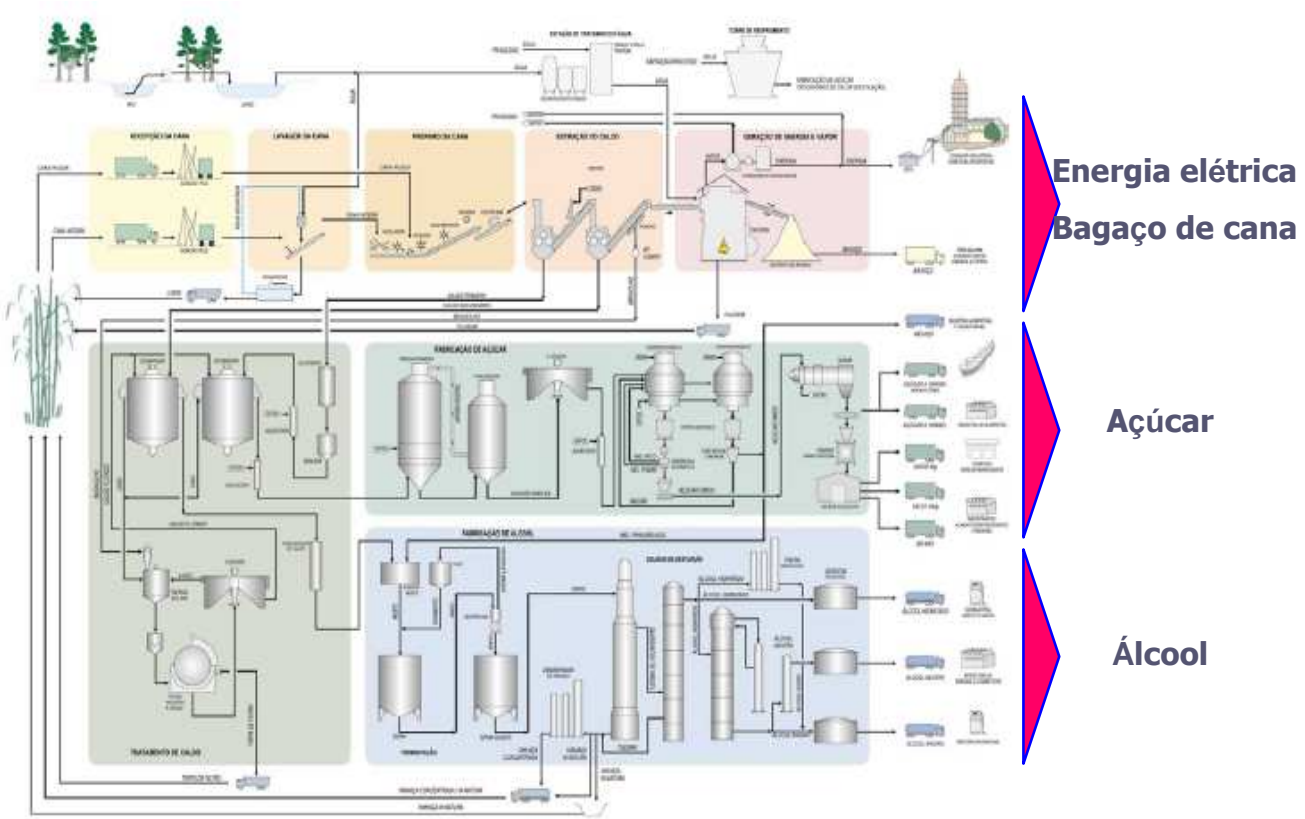

Figura 8 - Esquema ilustrativo do processo produtivo de uma usina de cana-de-açúcar Fonte: Companhia energética Santa Elisa, 2007

\subsection{Questões e perspectivas dos principais mercados consumidores de etanol}

\subsubsection{Mercado interno brasileiro e oflex fuel}

O consumo de etanol no Brasil tem crescido dramaticamente. Da safra 01/02 à safra 08/09, cresceu, em média, 10,9\% ao ano, conforme UNICA, 2009. Os incrementos tem sido significativos mesmo havendo oscilações caso a caso. Na safra 04/05 em relação ao ano anterior houve decréscimo de $7 \%$ retomando fortemente o crescimento nas safras de 2008 e 2009 com $35 \%$ e $21 \%$ respectivamente.

Estes dois últimos anos mesmo com a crise internacional que assolou também os canaviais. Interessante notar o crescimento significante também da produção e exportação de etanol, como um todo, na safra 2001/2002 até a safra 2008/2009 houve um crescimento médio de $13 \%$ e $37 \%$, respectivamente. Valores estes maiores até que os do consumo interno. A tabela 8 ilustra estas informações. 
Tabela 8 - Produção, exportação e consumo interno de etanol no Brasil desde safra 2001

\begin{tabular}{|l|r|r|r|r|r|}
\hline ano / safra & produção etanol & exportação & consumo interno & var & cagr01/09 \\
\hline $2001 / 2002$ & 11536,0 & 516,5 & 11019,5 & & \\
$2002 / 2003$ & 12623,2 & 817,6 & 11805,6 & $7 \%$ & \\
$2003 / 2004$ & 14808,7 & 956,1 & 13852,6 & $17 \%$ & \\
$2004 / 2205$ & 15416,7 & $2.478,2$ & 12938,4 & $-7 \%$ & \\
$2005 / 2006$ & 15947,0 & $2.615,6$ & 13331,4 & $3 \%$ & \\
$2006 / 2007$ & 17719,2 & $3.691,6$ & 14027,6 & $5 \%$ & \\
$2007 / 2008$ & 22526,8 & $3.624,8$ & 18902,0 & $35 \%$ & \\
$2008 / 2009$ & 27506,1 & $4.721,9$ & 22784,2 & $21 \%$ & $10,9 \%$ \\
\hline
\end{tabular}

Fonte: Autor apud UNICA, 2009

Outra dimensão relevante ao consumo interno do mercado brasileiro de etanol é relativa à divisão entre álcool anidro (puro) e hidratado. Este primeiro é adicionado à gasolina e o segundo para veículos movidos a álcool. Durante o período de meados dos anos 80 até começo dos anos 90 houve grande consumo de etanol hidratado por conta dos incentivos do Próalccol no preço do álcool combustível. A partir de meados dos anos 90, conforme Piacente (2006), houve contínua migração do consumo do etanol hidratado para a gasolina.

Por conta do fim do Proálcool e os incentivos relativos ao preço e associado à baixa mundial do preço do petróleo tornou-se mais vantajoso o uso de veículo á base de gasolina . A partir de 2003, no entanto a situação voltou a reverter, por conta do lançamento dos veículos flex-fuel, veículos automotores que poderiam ser abastecidos tanto por gasolina quanto por álcool hidratado e em qualquer proporção associado à redução dos preços do etanol garantiram um novo salto no consumo de etanol no Brasil. A figura 9 ilustra a evolução do consumo de etanol anidro ( misturado à gasolina ) e hidratado no Brasil. 


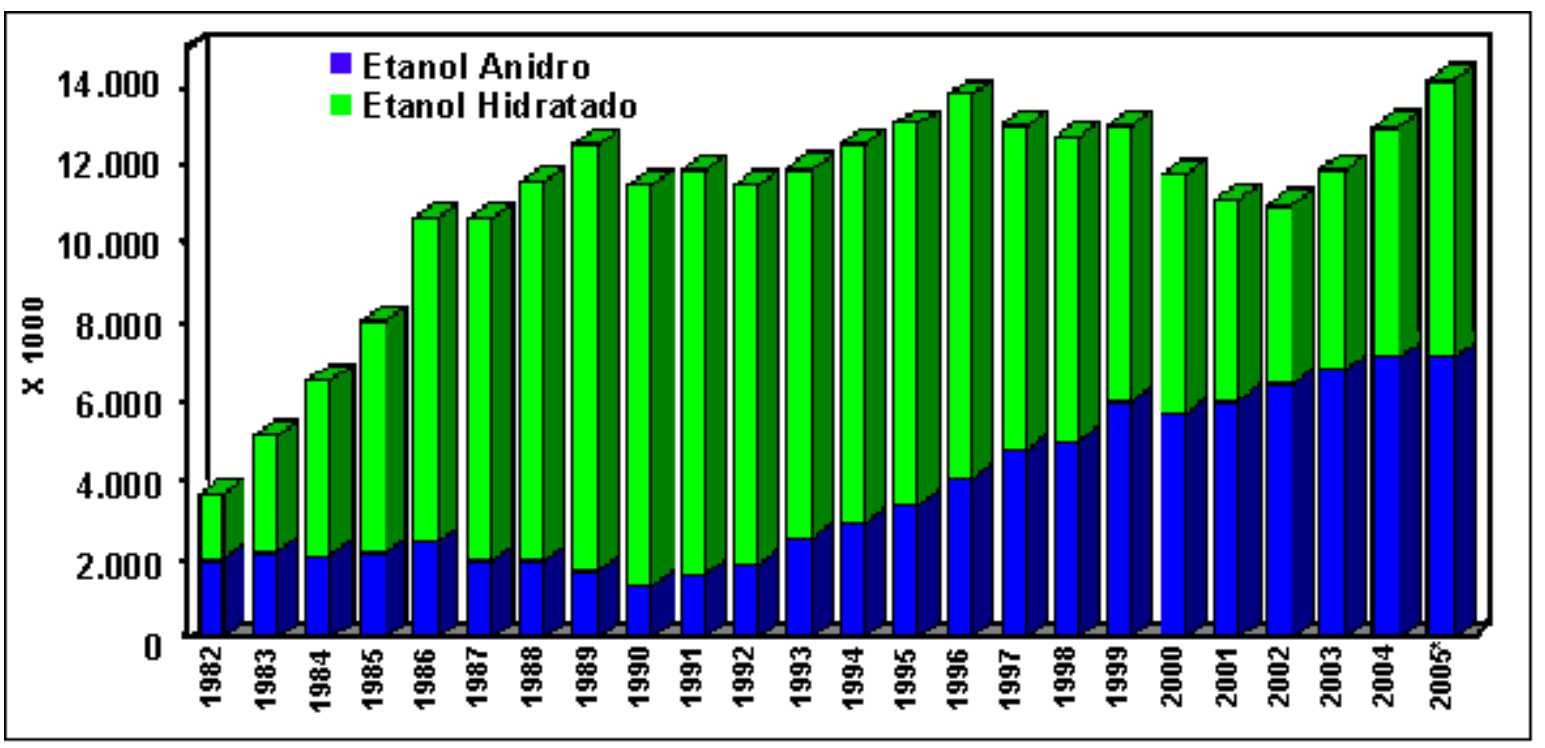

Figura 9- Evolução do consumo etanol anidro e hidratado no Brasil

Fonte: Piacente ,2006 apud Datagro (Nastari, 2005) e Copersucar (Oliveira, 2005)

\subsubsection{Veículo Flex fuel}

Conforme Piacente ( 2006), os veículos flex-fuel são automóveis ou utilitários leves com motores de Ciclo Otto e que funcionam com gasolina ou etanol hidratado puros ou em qualquer proporção destes combustíveis. Desta forma, gera ao proprietário do veículo a oportunidade de escolha de combustível em função da disponibilidade do mesmo, preço relativo entre ambos e características de desempenho do veículo.

A grande diferença estrutural na configuração dos motores entre os veículos flex fuel e os de um único combustível está no sistema de gerenciamento eletrônico da injeção e ignição do combustível. Esta tecnologia já vinha sendo desenvolvida há vários anos antes de década de 2000 no Brasil. A partir de 2002 quando os veículos flex fuel foram enquadrados na classificação do Imposto sobre produtos industrializados ( IPI) e classificados com o mesmo tratamento fiscal dos carros movidos a etanol vislumbrou-se definitivamente a oportunidade de lançá-los no mercado brasileiro. Em 2003 os primeiros veículos flex fuel foram lançados no país.

Conforme UNICA (2009), ao final de 2003 os veículos flex fuel representaram pouco mais de $3.8 \%$ do total de veículos leves vendidos no Brasil. Já ao final de 2008 representou pouco mais de $91 \%$ deste mesmo total. O crescimento nas vendas no mercado interno brasileiro tem sido astronômico, em média, $117 \%$ ao ano. Ao mesmo tempo por conta da substituição da frota, o consumidor deixa de comprar veículo à gasolina e compra o flex-fuel, as vendas dos veículos à gasolina caíram, em média, $30 \%$ ao ano. Em termos totais, as vendas 
de veículos leves no mercado brasileiro cresceram, em média, 14\% ao ano, empurradas pelo crescimento econômico do Brasil nestes últimos anos. Os dados da tabela 9 mostram a evolução deste crescimento.

Tabela 9 - Evolução da frota de automóveis e comerciais leves por tipo de combustível no Brasil

\begin{tabular}{|c|c|c|c|c|c|c|c|c|c|c|}
\hline \multirow[b]{2}{*}{ Anos } & \multicolumn{3}{|c|}{ AUTOMÓVEIS } & \multicolumn{3}{|c|}{ COMERCIAIS LEVES } & \multicolumn{3}{|c|}{ TOTAL } & \multirow[b]{2}{*}{ TOTAL } \\
\hline & GASOLINA & ÁLCOOL & FLEX-FUEL & GASOLINA & ÁLCOOL & FLEX-FUEL & GASOLINA & ÁLCOOL & FLEX-FUEL & \\
\hline 2002 & 1.181 .780 & 47.366 & - & 102.183 & 8.595 & - & 1.283 .963 & 55.961 & & 1.339 .924 \\
\hline 2003 & 1.046 .474 & 33.034 & 39.095 & 105.989 & 3.346 & 9.083 & 1.152 .463 & 36.380 & 48.178 & 1.237 .021 \\
\hline 2004 & 967.235 & 49.801 & 278.764 & 110.710 & 1.149 & 49.615 & 1.077 .945 & 50.950 & 328.379 & 1.457 .274 \\
\hline 2005 & 609.903 & 30.904 & 728.375 & 87.130 & 1.453 & 83.729 & 697.033 & 32.357 & 812.104 & 1.541 .494 \\
\hline 2006 & 260.824 & 1.650 & 1.293 .746 & 55.737 & 213 & 136.588 & 316.561 & 1.863 & 1.430 .334 & 1.748 .758 \\
\hline 2007 & 186.554 & 88 & 1.780 .876 & 59.106 & 19 & 214.214 & 245.660 & 107 & 1.995 .090 & 2.240 .857 \\
\hline 2008 & 127.896 & 68 & 2.065.313 & 89.125 & 16 & 263.934 & 217.021 & 84 & 2.329.247 & 2.546 .352 \\
\hline
\end{tabular}

Fonte : UNICA,2009 apud ANFAVEA, 2009

O principal fator de escolha ao consumidor para compra do etanol ou gasolina para abastecimento dos veículos flex fuel é a diferença de preço entre os combustíveis e a relação de desempenho entre os mesmos. As características físico químicas dos combustíveis como por exemplo: o poder calorífico e taxa de compressão nos motores fazem com que o rendimento dos veículos ( $\mathrm{km}$ rodados por litro de combustível consumido) movidos a etanol seja 30\% inferior, em média, aos mesmos veículos movidos à gasolina. Desta forma, a relação ótima para o preço do etanol em comparação ao da gasolina é quando o preço do derivado da cana-de-açúcar é inferior a $70 \%$ do preço da gasolina. Esta relação de preços na ponta ( ou na boca da bomba de combustível nos postos) ao consumidor torna-se portanto fundamental para as perspectivas agregadas de crescimento do consumo do etanol no mercado interno brasileiro.

Estudos já foram realizados procurando relacionar os preços ao consumidor entre o etanol hidratado e a gasolina buscando graus de dependência, ou não, entre elas. Os resultados destas pesquisas têm sido variados.

Avaliando estruturalmente, o fato é que o preço da gasolina nas bombas pouco varia relativamente com relação às flutuações internacionais do preço do petróleo, que por sua vez, é a matéria-prima principal da gasolina. Nos últimos anos o preço do petróleo oscilou demasiadamente chegando a patamares próximos a \$150 Dólares Americanos o barril e após a crise mundial de 2008, despencou para menos de $\$ 50$ dólares o barril. A despeito disso o preço da gasolina no Brasil manteve-se relativamente estável, não sendo repassadas ao preço do produto final as mencionadas variações de custo do petróleo. 
O preço do etanol, por sua vez, segue as leis de oferta e procura, oscilando durante o ano por conta das características sazonais da cultura da cana: o regime de chuvas, a produtividade dos canaviais e o processo de esmagamento da cana-de-açúcar e produção do etanol e custos logísticos. Ao mesmo tempo, a maturação dos projetos das usinas (leia-se investimentos fabris nas usinas e greenfields) impõe variações cíclicas de médio e longo prazos de aumento ou manutenção de oferta de etanol no mercado como um todo. Estas características podem ser visualizadas na figura 10.

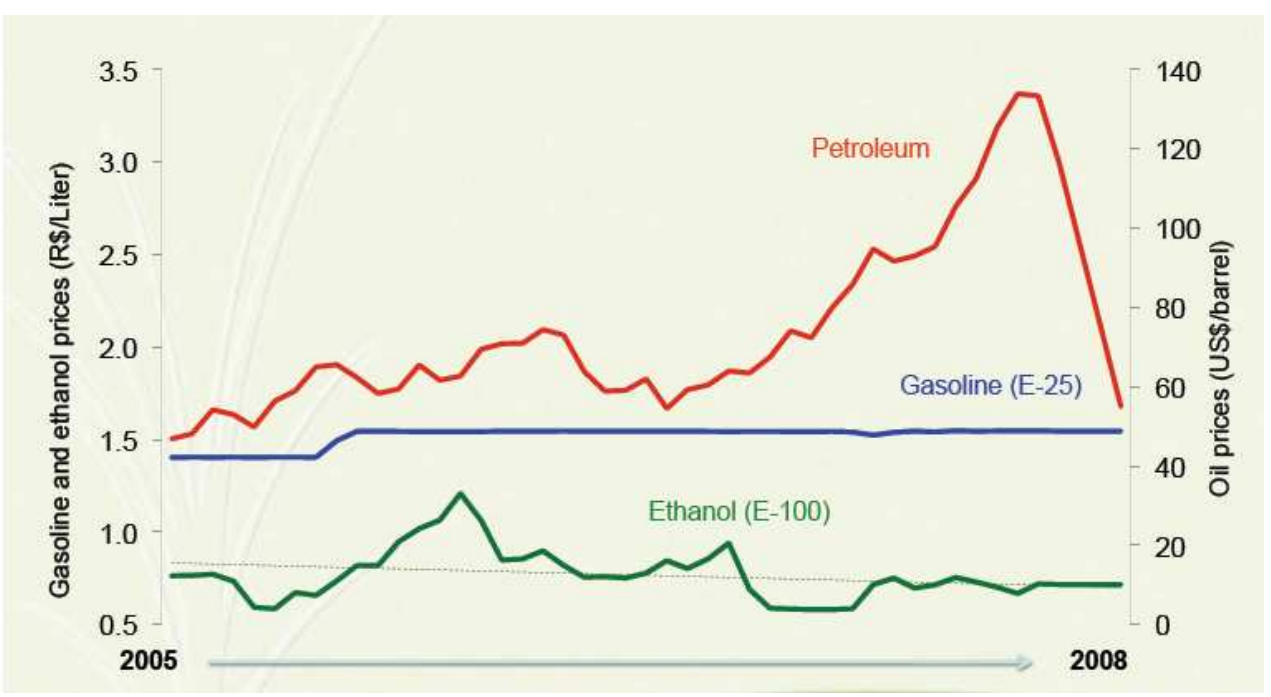

Figura 10 - evolução de preço, base 100, do petróleo, preço gasolina, preço etanol na ponta de consumo Fonte : UNICA, 2009

O Presidente da UNICA, Marcos Sawaya Jank , 2009 comenta:

[...] ao contrário da gasolina e do diesel, que têm seus preços artificialmente fixados pelo monopólio de facto da Petrobrás, os preços do açúcar, do etanol e da cana sofrem grandes variações de acordo com a lei de oferta e procura. Neste aspecto o etanol brasileiro é semelhante ao petróleo no mercado mundial, já que ambos flutuam ao sabor das leis de mercado.

Esta alegação tem sido recorrente pelos membros da cadeia produtiva da cana alegando que a manutenção do preço da gasolina alheia às variações do preço do petróleo afeta a competitividade do etanol e conseqüentemente o crescimento da demanda do mesmo. Isto porque o preço da gasolina impõe um limite superior ao preço do etanol, lembrando da relação de preços de $70 \%$ entre os combustíveis. 


\subsubsection{EUA}

Os Estados Unidos da América têm sido, nos últimos anos, o maior produtor e consumidor mundial de etanol. O acelerado crescimento no consumo de etanol nos EUA se deve primordialmente a: A busca estratégica por fontes alternativas de combustíveis na medida em que o país é altamente dependente do petróleo.

Conforme US Department of energy (2008), o petróleo, enquanto fonte primária, responde por $40 \%$ do total de energia consumida no país e representa (com seus derivados: gasolina, diesel, querosene etc.) 99\% do combustível utilizado nos meios de transporte. Apesar dos EUA serem um dos maiores produtores mundiais de petróleo, são, ao mesmo tempo , um consumidor ainda maior gerando déficit de sua balança comercial do petróleo. Conforme US Department of Energy, em 2008 a produção local anual foi de aproximadamente 1,8 bilhões de barris enquanto a importação foi de 3,6 bilhões de barris no mesmo período. Como a variação dos estoques finais não foi significativa em 2008 ( por volta de 0,04 bilhões de barris), pode-se considerar que o consumo total foi da ordem de 5,4 bilhões de barris em 2008. Ou seja, 66\% do petróleo consumido nos EUA é oriundo de fontes estrangeiras.

Outro aspecto significante, e que também expõe a vulnerabilidade do país, é no tocante às reservas de petróleo. Ainda conforme o US Department of Energy (2008), as reservas comprovadas de petróleo dos EUA em 2008 totalizavam 19,1 bilhões de barris. Em uma hipótese na qual os EUA consumissem apenas a produção local e suas reservas próprias sem utilizar de importações e sem novas descobertas de reservas e sem avanços tecnológicos e no perfil de consumo, as reservas existentes acabariam em menos de 4 anos.

Outro fator que explica o crescimento do consumo do etanol nos EUA, e em decorrência do exposto anteriormente, é a escolha estratégica do governo norte-americano de fontes renováveis e limpas de energia como alternativa ao petróleo. Neste sentido o etanol se destaca em função, além de ser limpa e renovável, pelo fato dos EUA poderem utilizar a infra-estrutura e tradição já existentes da produção de grãos e, em especial a cultura do milho, para a transformação em etanol. Ainda neste contexto, o etanol é passível de avanços tecnológicos, por exemplo: o etanol celulósico. Desta forma, os EUA com soluções de curto prazo: utilização de milho norte-americano para produzir etanol e longo prazo: desenvolvimento de tecnologia local para novas formas de produzir etanol diminui o risco e a dependência do país de fontes estrangeiras de energia. 
Conforme apresentado por Rodrigues, T. R. ( 2009) , os EUA desde 2004 passou a ser o maior produtor mundial de etanol ( á base de milho) desbancando a posição de liderança mundial na produção de etanol do Brasil. Em 2009 a expectativa é que os EUA produzam aproximadamente 40,4bilhões de litros de etanol, o que representaria uma taxa de crescimento médio de $22 \%$ ao ano desde 2003. Taxa de crescimento esta bem acima taxa brasileira, conforme mostrado no item 2.2.1 da ordem de $10.9 \%$ ao ano desde 2001. Ao mesmo tempo, os EUA são o maior consumidor mundial de etanol representando, aproximadamente $45 \%$ do consumo mundial, ou, 45,6 bilhões de litros em 2009, estimativamente. A tabela 10 elucida estas questões:

Tabela 10 - Principais produtores mundiais de etanol ( milhões de litros/ano)

\begin{tabular}{|l|r|r|r|r|r|r|r|}
\hline & $\mathbf{2 0 0 3}$ & $\mathbf{2 0 0 4}$ & $\mathbf{2 0 0 5}$ & $\mathbf{2 0 0 6}$ & $\mathbf{2 0 0 7}$ & $\mathbf{2 0 0 8}$ & $\mathbf{2 0 0 9}$ \\
\hline Brasil & 14674 & 15302 & 15982 & 17704 & 22156 & 26840 & 27836 \\
\hline Eua & 12045 & 14307 & 16237 & 19832 & 25917 & 36280 & 40484 \\
\hline China & 3522 & 3673 & 3438 & 3855 & 4071 & 4328 & 4631 \\
\hline União Europ. & 2571 & 2587 & 2950 & 3669 & 4076 & 4782 & 7854 \\
\hline India & 1349 & 1178 & 1120 & 1664 & 2082 & 1725 & 1750 \\
\hline Total & $34161^{-}$ & $37047^{-}$ & $39727^{-}$ & 46724 & 58302 & $73955^{\circ}$ & 82555 \\
\hline
\end{tabular}

Fonte: Rodrigues, T. R., 2009

Os primeiros movimentos consistentes no mercado americano para uso do etanol como combustível para transporte datam do início dos anos 1990 quando duas ações de impacto foram introduzidas: o ato de política energética de 1992 que previa o E-85 (85\% etanol, $15 \%$ gasolina em volume) como combustível alternativo para transporte. O Clean Air Act Amendment do mesmo ano estabelecia que, em áreas urbanas poluídas selecionadas, a gasolina vendida deveria conter oxigenantes (com o objetivo de reduzir a emissão de poluentes) e sugerindo o etanol como o principal deles. A partir daí outras medidas governamentais objetivando reduzir a dependência americana dos combustíveis fósseis vem sendo introduzidas e proporcionando o aumento do consumo de etanol naquele país. Em 2005 o Energy Policy Act instaurou o chamado Renewable Fuels Standard ( RFS) previu que a gasolina vendida tivesse um mínimo de combustíveis renováveis adicionados à gasolina . Em 2007 foram expandidas as medidas previstas no RFS e que 36 bilhões de galões de combustíveis renováveis fossem adicionados á gasolina, diesel e querosene de aviação até 2022. 
Um indicativo da utilização de etanol nos veículos nos EUA é que, conforme EIA (2009), em 2007, a maior parte da frota de veículos automotores leves e médios que utilizavam combustíveis alternativos nos EUA utilizavam a mistura E85 (85\% etanol, 15\% gasolina em volume) como fonte energética representando $73 \%$ do total, enquanto os veículos híbridos gasolina-elétrica, amplamente divulgados em campanhas promocionais na mídia por alguns fabricantes ( particularmente a montadora Toyota com o veículo Prius ) representavam 26\% do total. A tabela 11 mostra ainda que vários tipos veículos leves (automóveis, minivans, vans, pick-ups e Sport Utility Vehicles -SUV's ) utilizavam o E85 enquanto automóveis, em sua maioria, e alguns $S U V$ 's utilizavam motorização híbrida gasolinaelétrica. Apesar dos avanços dos veículos movidos a etanol, os veículos movidos a combustíveis alternativos ainda representam menos de $1 \%$ do total da frota americana conforme US Department of Energy ( 2009).

Tabela 11 - Frota de veículos automotores leves e médios que utilizam combustível alternativo nos EUA, 2007

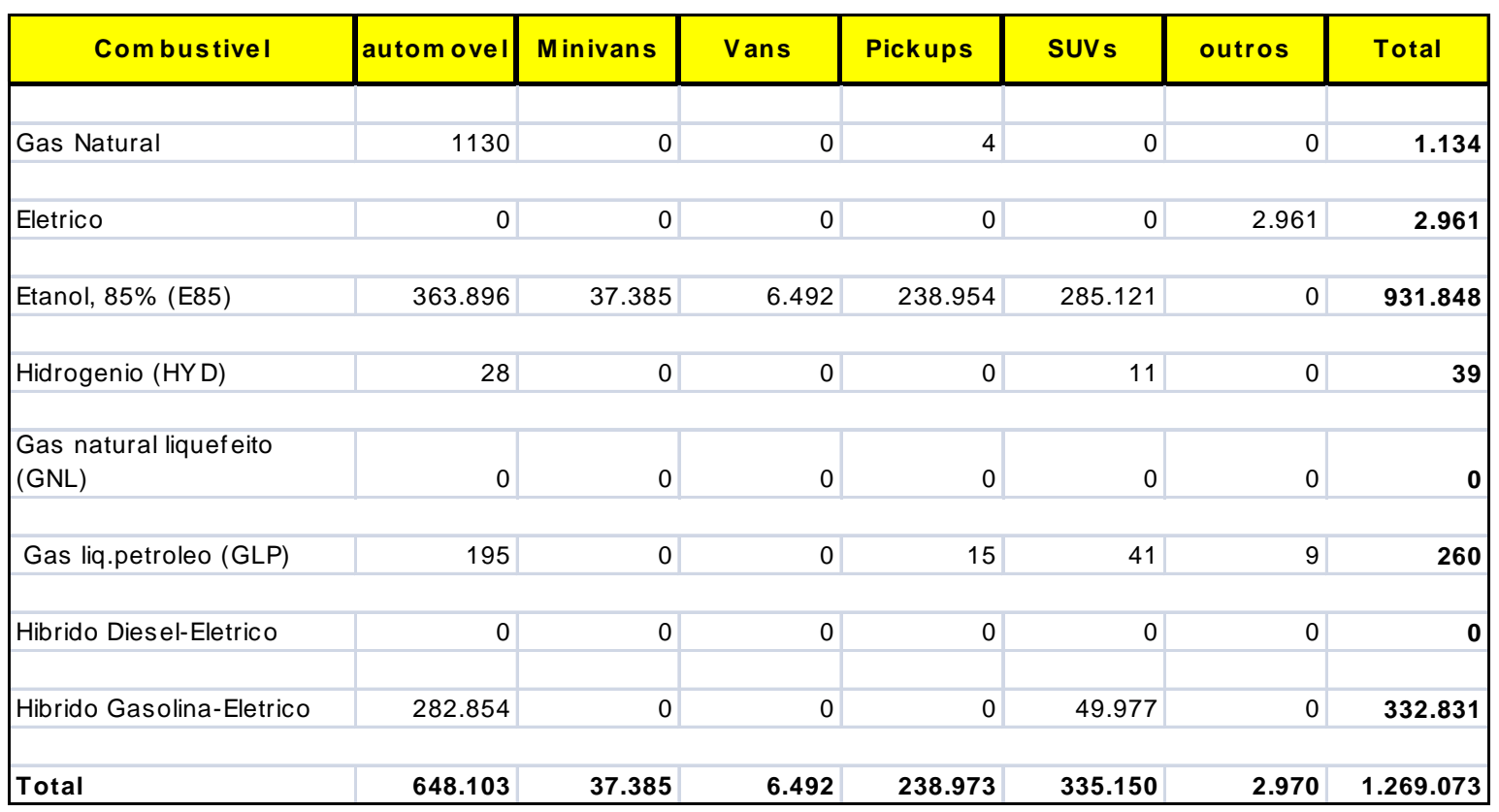

Fonte: EIA , 2009

Outra questão fundamental relacionada ao etanol norte americano é a competitividade, em custo, do etanol do milho em comparação a ao etanol de outras culturas. É seguro afirmar que o custo de produção do etanol do milho norte americano é maior que o do etanol de canade-açúcar brasileiro. Por conta dos fatores da competitividade e da estratégia de país para o desenvolvimento da cadeia produtiva do etanol do milho, incentivos fiscais são dados aos 
produtores locais e, ao mesmo tempo, barreiras comerciais são impostas à importação de etanol de outras localidades. Estimativas prevêem que US\$11,5 bilhões em incentivos fiscais foram concedidos aos produtores de etanol do milho entre os anos 1980 e 2000. As barreiras tarifarias impostas às importações são impostas através de alíquota Ad Valorem de 2,5\% mais US\$0,54 por galão de etanol importado ( equivalente a aproximadamente US\$,014 /litro de etanol) Piacente (2006).

Mecanismos, no entanto, são utilizados para as necessidades de importações devido ao desbalanceio de produção e consumo. O Caribbean Basin Iniciative (CBI) promove a isenção dos US\$0,54/galão das importações oriundas de países do Caribe, o que propicia a oportunidade de entrada em solo americano, passando pelo Caribe, do produto brasileiro com um custo mais competitivo. Outras medidas de incentivo para o etanol americano estão inseridas no Energy Bill 2005 no qual isenta US\$0,51 de imposto federal por galão de combustível que contenha $10 \%$ de etanol. O crédito aumenta ainda de US\$0,05 por galão por ponto percentual de etanol adicionado à gasolina. Estes subsídios previstos para vigorar até 2007 foram estendidos até 2010, conforme Bastos (2007).

Conforme Macedo e Nogueira (2005), é difícil estimar o custo de produção unitário do etanol de milho nos EUA, dado os incentivos fiscais atribuídos aos mesmos. De qualquer forma em um estudo de caso de planta de médio porte e em condições específicas o custo estimativo de produção chega a US\$0,33/litro. Plantas maiores, contabilizando ganhos de escala poderiam chegar a um custo unitário de produção de US\$0,29/litro. Neste caso seria equivalente a US\$1,10 o galão. Os autores não mencionam, mas pode-se esperar que estejam contemplados apenas os custos operacionais sem considerar os custos de capital.

Pesquisa realizada em 21 usinas nos EUA por levantaram os custos operacionais de produção de etanol de milho estão da ordem de US\$0,96 o galão. Os custos de capital que, em média na pesquisa, representavam US\$1,57 o galão totalizando US\$2,53 /galão ou aproximadamente US\$0,67 / litro. Os custos totais do etanol de cana-de-açúcar brasileiro estariam por volta de US\$1,10 o galão, conforme Bastos (2007). 


\subsubsection{Comunidade Européia}

Em Maio de 2003, o Parlamento Europeu definiu através da Diretiva para utilização de biocombustíveis e outros combustíveis renováveis. Segundo tal Diretiva, poderia contribuir para reduzir a dependência de importar energia e contribuir para diminuir a emissão de gases causadores do efeito estufa. Entende-se por biocombustíveis, combustíveis líquidos ou gasosos para utilização em transporte e produzido a partir de Biomassa. Outros combustíveis renováveis referem-se a combustíveis renováveis que não sejam biocombustíveis. (FIGUEIRA E BURNQUIST, 2008) .

Para obtenção dos benefícios almejados, cada país membro do Parlamento Europeu deveria colocar proporções mínimas nos combustíveis de seus países biocombustíveis e outros combustíveis renováveis e o estabelecimento de metas indicativas para este efeito. Até 31 de Dezembro de 2005, todos os países membros deveriam ter no total de combustíveis vendidos em seus respectivos países, um mínimo de $2 \%$ de biocombustíveis e outros combustíveis renováveis conforme Figueira e Burnquist (2008). Tal orientação poderia gerar uma demanda potencial de aproximadamente 4 Bilhões de litros de biocombustíveis nestes países. (PIACENTE,2006). No entanto, a meta não foi alcançada tendo tido como resultado médio 1,4\% de biocombustíveis e outros combustíveis renováveis (BASTOS, 2007).

Incremental às metas para 2005 estão previstas também a meta de utilização de 5,75\% até 2010 e $20 \%$ até 2020 ( Directive 2003/03EC). Conforme Bastos (2007) a meta de 5,75\% em 2010 exigirá um aumento de capacidade de 12 Bilhões de litros de combustíveis/ano e investimentos de ordem de $€ 7$ Bilhões. Inclusive para atingir tal meta seriam necessárias importações expressivas de etanol de países como o Brasil ,que representa mais de $40 \%$ das importações para os países europeus.

No entanto, a atitude dos países europeus quanto à importação e conseqüentemente os riscos dos produtores locais é bastante conservadora e restritiva. Conforme Piacente (2006), a evolução da meta de utilização de biocombustíveis, em média, de $0,75 \%$ ao ano, sugere extrema precaução na adoção deste tipo de combustível propiciando assim o desenvolvimento tecnológico local antes da adoção em larga escala. Esta adoção paulatina propiciaria o ganho de escala e minimização de riscos do colapso dos produtores europeus de biocombustíveis.

De fato, como comenta Bastos (2007), assim como nos Estados Unidos, as linhas de ação dos países europeus tem se orientado para a pesquisa de novas tecnologias para a produção de etanol celulósico e utilização de biorefinarias. O principal objetivo na pesquisa inclui a redução de custos de 30\%, em média, a partir de 2010. Os Projetos Integrados 
Renew18 e Nile19 são considerados ações-chave no desenvolvimento em escala piloto da segunda geração de biocombustíveis e liderado pelo Institut Français du Pétrole.

Com relação à oferta e demanda de etanol nestes países, conforme tabela 10 a produção total estimada de etanol na comunidade européia em 2009 seria de 7,8 bilhões de litros e o consumo conforme Rodrigues, T. R. ( 2009 ) da ordem de 10,2 Bilhões de litros. Estes dados demonstram o déficit do continente neste insumo energético.

Alemanha, França, Espanha e Suécia são os maiores produtores de etanol, que por sua vez, é essencialmente produzido a partir de beterraba e trigo. Poucos países europeus têm balança comercial do etanol favorável, como é o caso da França. A Espanha, por sua vez, tem balança em equilíbrio entre oferta e demanda. Já o Reino Unido, a Alemanha, a Itália e a Suécia possuem déficit na balança comercial. O deficit da balança alemã é significativo, pois ocorre mesmo com pesadas taxações á importação de etanol ( €0,19/litro) enquanto países como Reino Unido e Itália taxam as importações por volta de (€0,10/litro). (RODRIGUES, T. R., 2009).

Os países europeus, em sua maioria, são bastante agressivos quanto às metas objetivando a utilização de biocombustíveis. Por outro lado, estão em uma situação bastante frágil quanto à agroindústria local. De qualquer forma, para o Brasil, é um dos principais mercados para exportação do etanol.

\subsubsection{Japão e outros países}

O Japão possui amplo potencial de consumo de etanol para próximos anos. Conforme Rodrigues, T. R. (2009), o Japão possui a segunda maior frota de veículos automotores do mundo, sendo que a maior está nos EUA. $82 \%$ de sua matriz energética é oriunda de fontes estrangeiras dada a sua limitação territorial e natural. Importa praticamente todo o petróleo utilizado no país (99.5\%). O Japão tem particularmente várias características que o qualificam como um dos maiores importadores do etanol brasileiro. Nestes últimos anos o interesse pelo combustível do Brasil tem se intensificado. Em 2008 foram importados do Brasil 263 milhões de litros de etanol e de Janeiro a Setembro 2009 as exportações brasileiras de etanol para o Japão cresceram $61 \%$ em relação ao mesmo período do ano anterior.

A utilização de etanol no Japão ainda é incipiente, porém o potencial de crescimento é significativo dado o interesse do país na utilização de fontes renováveis de energia. Em 2003 
o governo japonês estabeleceu o renewable portfolio act definindo metas para a substituição de fontes combustíveis fósseis por renováveis conforme Macedo e Nogueira (2004) .

Procura assim diversificar a matriz energética, reduzindo a dependência de combustíveis fósseis. Um incremento significante, no entanto, foi do uso da energia nuclear passou de 1980 a 2001 na composição da matriz energética japonesa de 4,7\% para 12,6\% respectivamente. Já as novas tecnologias, nas quais se enquadram as energias renováveis passaram de 1,0\% para 2,3\% no mesmo período, conforme Piacente (2006).

O consumo de etanol do Japão se deve essencialmente à utilização do mesmo nos veículos automotores em substituição à gasolina. Como signatário e anfitrião do Protocolo de Quioto objetiva a redução na emissão de gases de efeito estufa , até 2012, para nível de 94\% das emissões de 1990. Atualmente o governo japonês incentiva, mas não obriga, a utilização de 3\% de etanol na gasolina. Espera-se para os próximos anos, inclusive iniciando em 2010, a obrigatoriedade da utilização de $10 \%$ de etanol na gasolina. O que viria a representar uma grande oportunidade de exportação ao Brasil. As negociações internas no país para adoção de metas mais agressivas do uso do etanol se tornaram morosas na medida em que resistências do setor petrolífero e a incerteza dos japoneses quanto às fontes de fornecimentos (regularidade e segurança) são sentidas conforme Piacente ( 2006).

De qualquer forma ações pontuadas de empresas japonesas, especificamente as trading companies dentro do modelo tradicional japonês de realizar negócios, tem desenvolvido parcerias junto a empresas brasileiras no sentido de intensificar as exportações de etanol do Brasil para o Japão. Empresas como Mitsui pelo Japão e Coimex, Petrobrás e Vale pelo Brasil são exemplos de empresas que tem estreitado seus negócios neste sentido.

A China é o terceiro maior produtor mundial de etanol conforme estimativa da tabela 10 espera-se em 2009 a produção de aproximadamente 4,6 Bilhões de litros. As fontes agrícolas para produção do etanol são o milho, em sua maioria, e o trigo. Pouco na China se utiliza o etanol como combustível para veículos, em sua maior parte é utilizado como bebidas, insumo industrial e farmacêutico.

No entanto o governo chinês é favorável à utilização do etanol como substituto da gasolina, inclusive sendo mencionado, mas não confirmado, a substituição de $10 \%$ da gasolina por etanol. Neste cenário, a capacidade produtiva chinesa não conseguiria dar conta da demanda e as importações teriam de ser realizadas mais intensivamente. Mesmo com o 
anúncio de investimentos e construção de usinas de produção de etanol como, por exemplo, da empresas chinesa Jilin Fuel Ethanol que construiu em 2005 umas das maiores usinas de etanol do mundo com a capacidade de produzir 670 milhões de litros de etanol por ano.

Por conta da necessidade de desenvolvimento da infra-estrutura tecnológica e industrial chinesa, várias missões tecnico-econômicas têm sido feitas por representantes chineses ao Brasil para aprender com o exemplo brasileiro no etanol de cana-de-açúcar conforme Piacente (2006) .

Por enquanto os negócios realizados entre Brasil e China quanto à importação de etanol ainda é pequena. Conforme UNICA (2009), em 2008 foram contabilizadas exportações diretas à China de apenas 4 milhões de litros de etanol do Brasil.

Os demais países não possuem, neste momento, consumo significativo de etanol. Em 2008, o consumo total na África e Austrália fora de apenas 1,1 e 0,2 bilhões de litros respectivamente, conforme Rodrigues T. R. (2009).

\subsection{Logística de distribuição do etanol brasileiro}

Após avaliar as algumas características que envolvem o etanol de cana no Brasil, a discussão passará acerca da logística de distribuição do mesmo. Dado o potencial de crescimento da oferta do etanol á base de cana-de-açúcar no Brasil para os próximos anos seja para abastecer a demanda do mercado local, essencialmente para suprir os veículos automotores flex-fuel, ou a demanda do mercado externo, a interação entre os vários agentes envolvidos neste tema ( agentes econômicos, sociais, políticos e ambientais ) em níveis de percepção diferentes ( assimetria de informações, agendas e interesses diversos ) tem levado esta cultura agrária, e vista sob a perspectiva agregada, a entraves e gargalos. Um destes gargalos, a Logística de distribuição no Brasil do Etanol, complexo por natureza em função dos agentes envolvidos e pela necessidade de investimentos de largo alcance ( financeiro e no tempo) . Na medida em que o etanol de cana do Brasil tem tomado importância global, mais e mais se direcionando para ser uma commodity internacional de baixo valor agregado, na medida em que concorre diretamente com a gasolina. Desta forma, a logística do etanol se torna chave, pois pode ou não garantir o atendimento à demanda crescente e a viabilidade em termos de custo. 


\subsubsection{Logística interna}

Conforme mencionado anteriormente, a maior parte da produção de etanol no Brasil está concentrada no estado de São Paulo, aproximadamente 65\% do total. Ao mesmo tempo, a maior parcela do consumo do etanol também acontece no Estado de São Paulo. Conforme ANP (2008), em 2007 59\% do consumo de álcool hidratado no Brasil se localizou no estado de São Paulo .

Por um lado é uma situação favorável á logística de distribuição pela proximidade entre o maior centro de produção e de consumo interno. Por outro lado, a necessidade de ter custos baixos requer a disponibilidade de diferentes modais de transporte do etanol. É sabido que o estado de São Paulo possui as melhores estradas do país, e isso facilita o escoamento da produção do etanol, mas não é apenas com o transporte rodoviário que se conseguirá garantir a entrega do etanol em condições ótimas. É preciso considerar outras possibilidades como o transporte ferroviário, aquaviário e dutoviário que melhor se acomodar.

Uma temática crítica ao analisarmos a logística é o custo de transporte envolvido por modal e a conseqüente escolha entre os mesmos, objetivando o menor custo logístico. Dentro desta visão, diferentes cenários podem ser avaliados em função dos pontos de abastecimento e destinos geográficos finais. Por um lado, os custos unitários de transporte ( $R \$ / \mathrm{m}^{3}-\mathrm{km}$ ) para os modais rodoviário , ferroviário , hidroviário e dutoviário são, nesta ordem, ascendentes. Por outro lado, os investimentos necessários para a infra-estrutura são inversamente crescentes nos referidos modais. Ainda, os investimentos no caso do modal dutoviário apenas são viabilizados em função da escala (vazão ) gerada conforme Figueiredo ( 2005).

Também conforme discutido anteriormente, a interiorização do plantio da cana e a produção de etanol por conta do esgotamento e encarecimento de terras aptas á criação de novos greenfields gera impactos logísticos significativos.

O avanço da fronteira agrícola para o centro-oeste e a concentração da oferta nesta área do país faz com que se afaste dos maiores centros consumidores, que estão localizados próximos ao litoral do Brasil por razões históricas e econômicas. A figura 11 ilustra esta questão. 


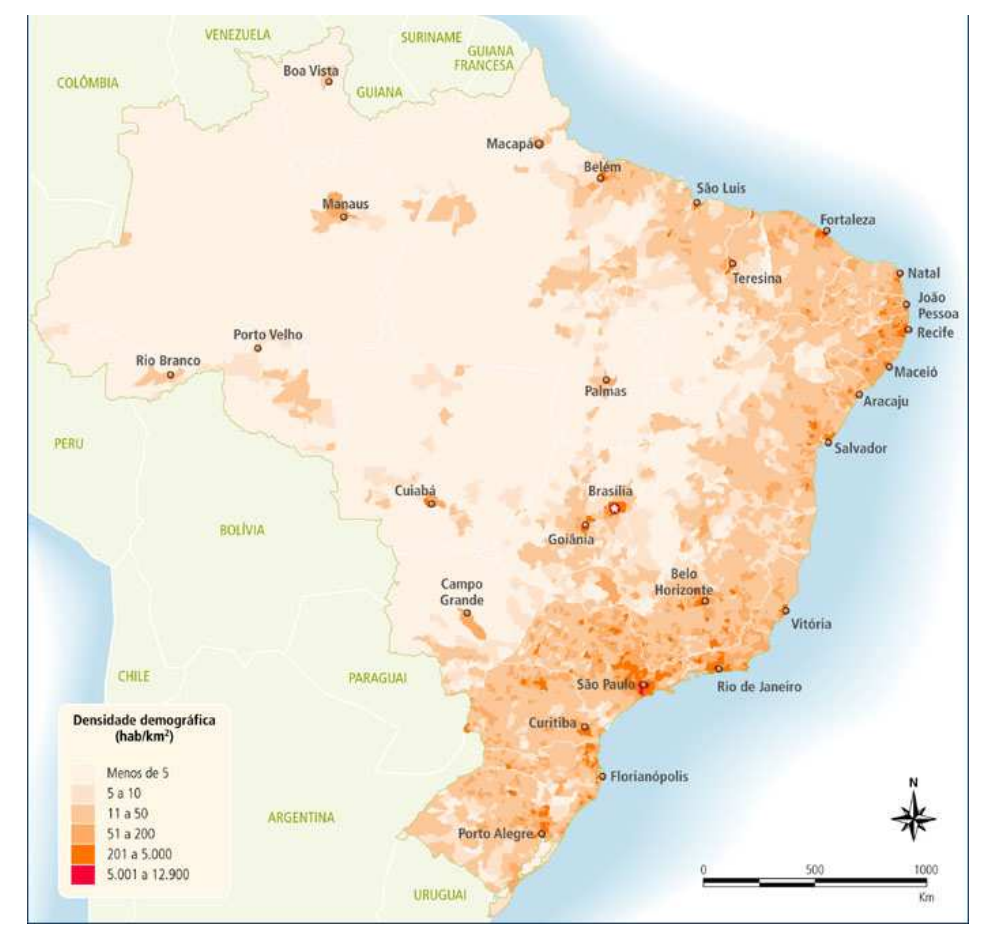

Figura 11 - Distribuição espacial da população brasileira- Censo demográfico 2000

Fonte: IBGE, 2009

Ao mesmo tempo, a concentração da produção de etanol e a pulverização do consumo distancia os centros produtores dos centros consumidores tendo conseqüentemente implicações logísticas e, por sua vez, de custos.

Conforme ANP (2008), a maioria dos estados brasileiros apresentou deficit com relação à oferta de demanda de etanol. Isto é, consomem mais etanol do que produzem.

Apesar de apenas a região norte do Brasil, como um todo, ser deficitária, na avaliação por estado, 16 das 27 (ou 59\% do total ) unidades federativas são deficitárias quanto à produção e consumo de etanol ( hidratado) conforme mostra figura 12. 


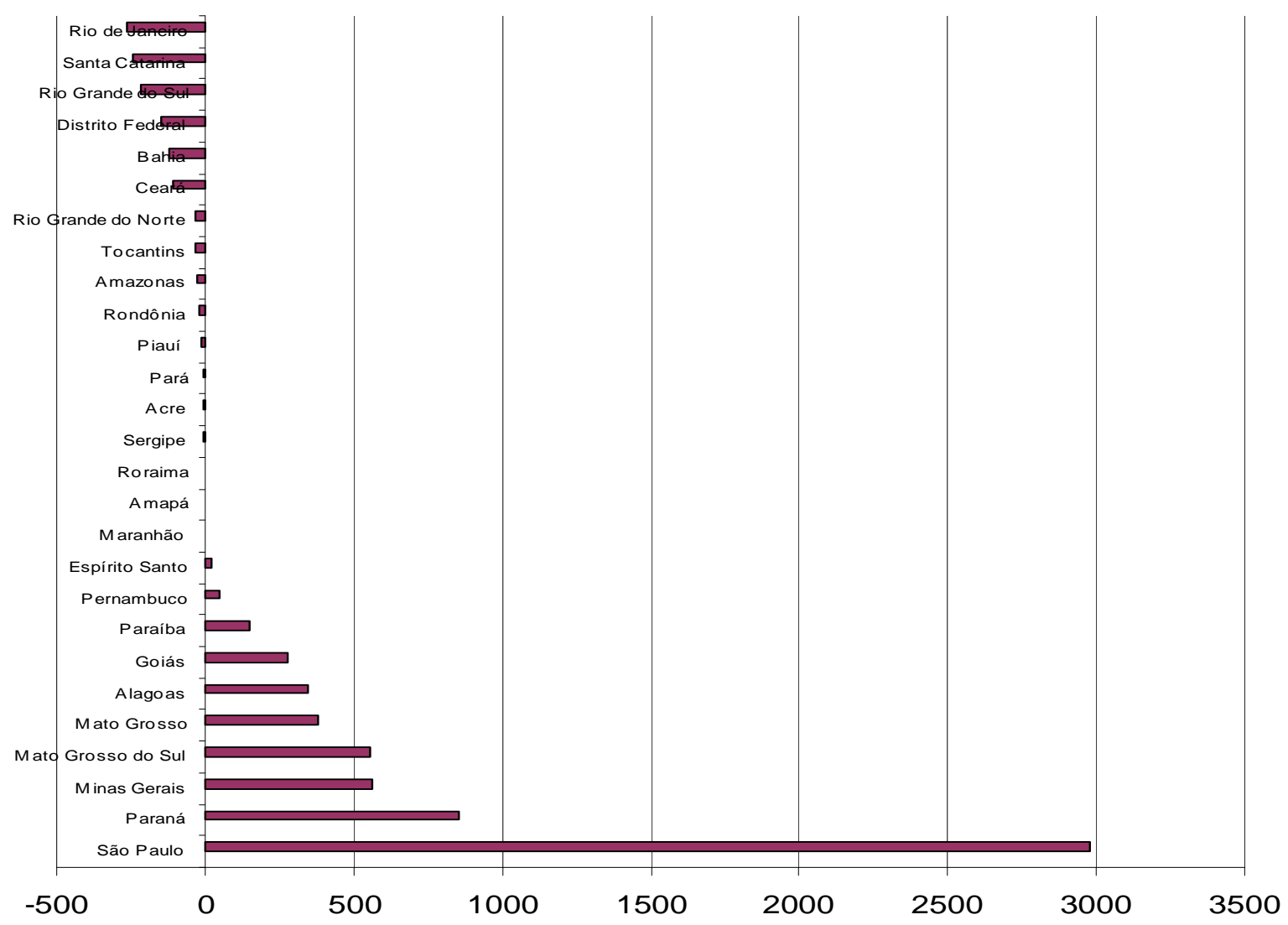

Figura 12 - Saldo de produção e consumo de etanol hidratado no Brasil , 2007 (mil m3)

Fonte: Ator adaptado ANP, 2008

O perfil brasileiro de concentração de produção e distanciamento de centros consumidores também se verifica nos EUA, o maior produtor mundial de etanol. Conforme Colin et al ( 2009), a produção de etanol de milho nos EUA está dispersa em 20 estados mas a produção de etanol se concentra nos estados do "Corn Belt" : Iowa, Nebraska, Illinois, Minnesota, South Dakota, Indiana, Kansas e Wisconsin, conforme a figura 13 ilustra.

Por outro lado, o consumo se concentra particularmente em estados como Califórnia e os da região da Nova Inglaterra. 

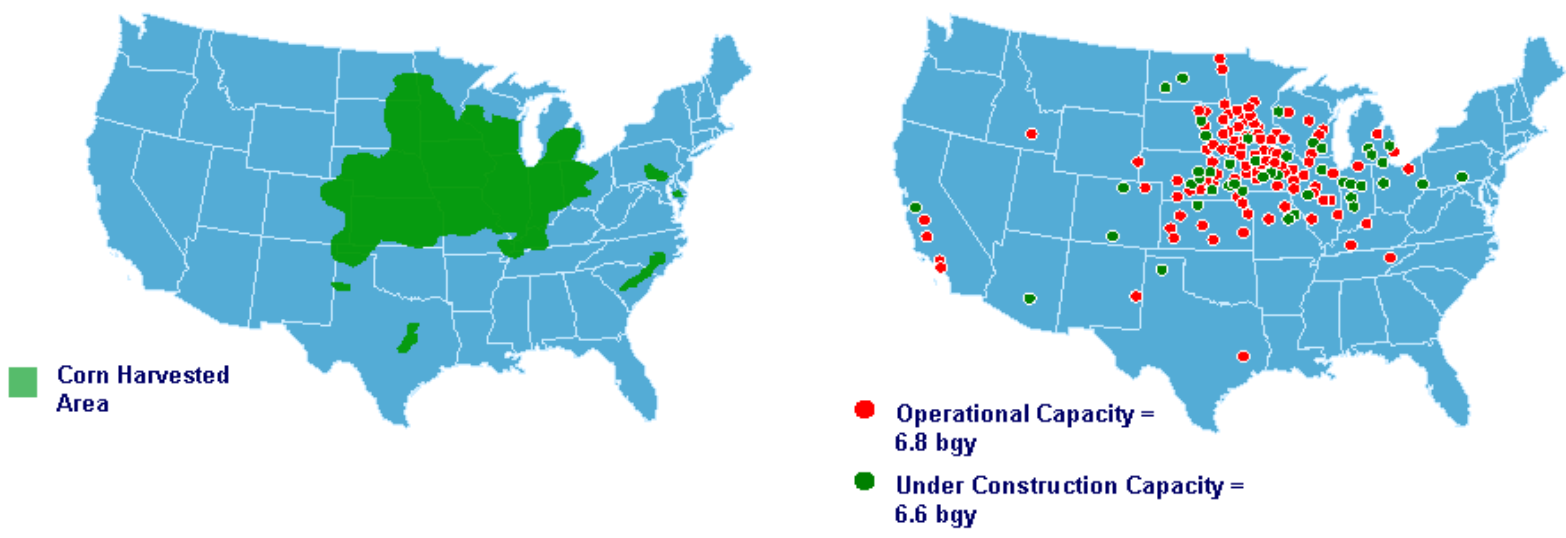

Figura 13 - Distribuição geográfica da produção de milho e etanol nos EUA, 2006

Fonte: Colin et al , 2009

No caso do Brasil, a concentração da produção em alguns estados do centro-sul e a distância de centros consumidores particularmente no norte-nordeste, faz com que o preço final do etanol ao consumidor não seja competitivo com relação à gasolina.

Segundo Figueiredo (2005), o modelo de distribuição de combustíveis no Brasil é, genericamente, dividido em três grandes fluxos: Primário, transferência e entrega. O primário, onde o álcool é transportado das usinas para as bases primárias ou secundárias (diferenças relativas ao porte da estocagem e a proximidade com os mercados consumidores finais). Neste sistema essencialmente o transporte é primordialmente ferroviário e rodoviário.

Transferência ocorre quando existe um transporte entre as bases primárias para secundárias e a consequientemente a aproximação dos estoques dos centros consumidores. Neste caso o deslocamento é de grandes distâncias permitindo assim o uso modal dutoviário.

Entrega se caracteriza quando existe o transporte entre as bases primárias ou secundárias para os clientes próximos aos mercados consumidores. Neste caso o modal utilizado é rodoviário devido à pulverização dos pontos finais e os pequenos volumes envolvidos. A figura 14 ilustra os fluxos envolvidos. 


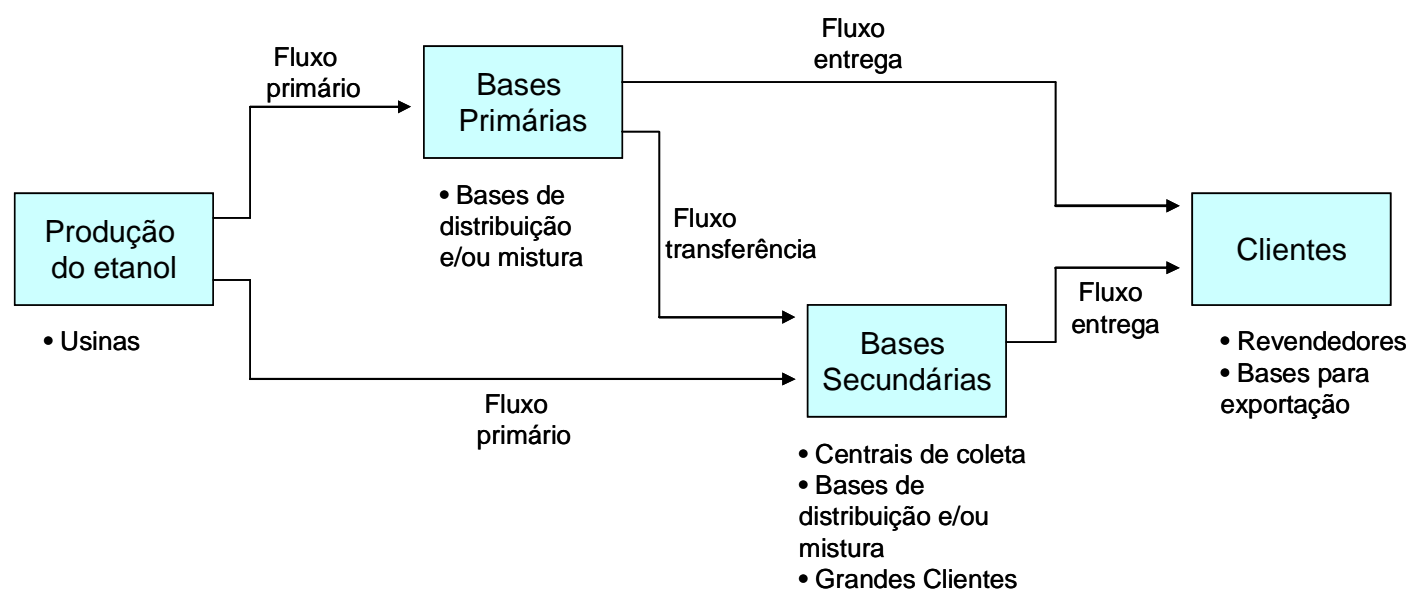

Figura 14 - Fluxo de distribuição logística do etanol no Brasil

Fonte: Autor adaptado Figueiredo, 2005 e Xavier, 2007

Existem, conforme Sindicom (2007), aproximadamente 550 bases primárias e secundárias para a distribuição de combustíveis líquidos no Brasil conforme mostra a figura 15. Fica clara complexidade da distribuição de combustíveis no Brasil. As bases primárias, por estarem próximas aos centros de produção, localizam-se próximas à costa brasileira, com exceção à base de Manaus.

A distribuição das bases primárias para as secundárias utiliza o modal ferroviário particularmente na região nordeste e sul para seu interior e a região sudeste para seu interior e a região centro-oeste. Já o modal hidroviário é utilizado para a distribuição na região norte a partir de Manaus e Belém.

O modal rodoviário é utilizado principalmente na distribuição entre bases secundárias nas regiões centro-oeste e norte do país. Por fim o modal dutoviário é utilizado em algumas rotas entre bases no sul, sudeste e nordeste. Além de ser foco de investimento para distribuição do etanol orientado para a exportação. 


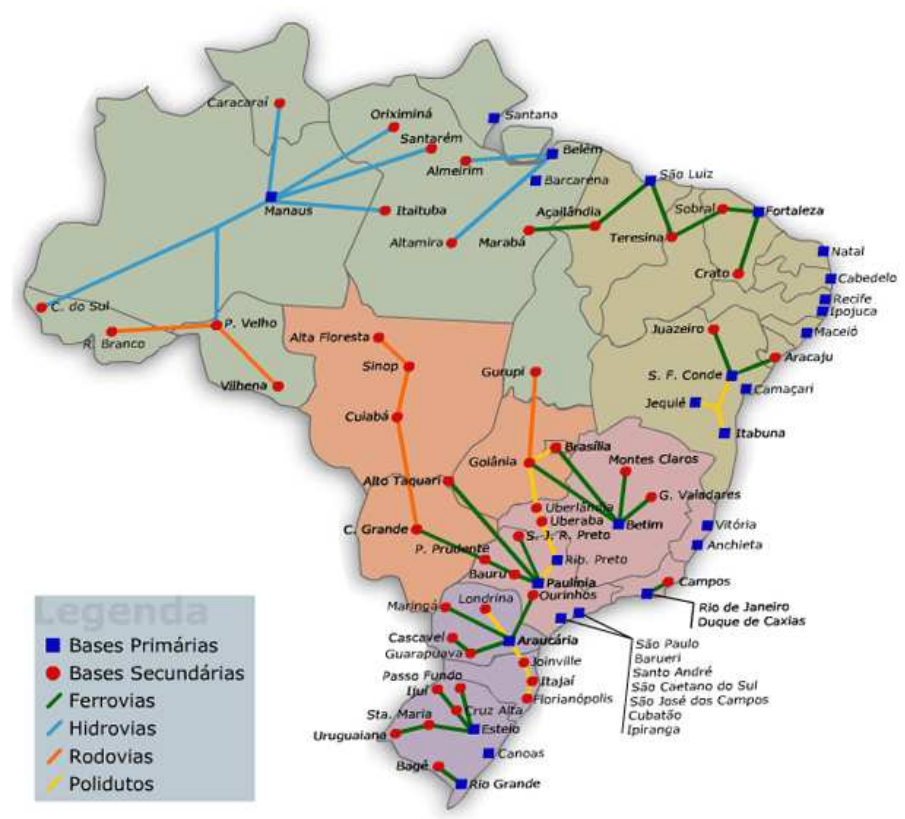

Figura 15 - Distribuição geográfica de infra-estrutura de combustíveis líquidos no Brasil

Fonte : Sindicom , 2007

Ao mesmo tempo, a distribuição na ponta (postos de combustíveis) é complexa pela extensão territorial do Brasil. Conforme Sindicom (2007), em 2007 existiam no Brasil 34300 postos de revenda combustíveis, dos quais $90 \%$ vendiam etanol hidratado e $65 \%$ do total estavam localizados nas regiões sudeste e sul do país A figura 16 ilustra estes aspectos.

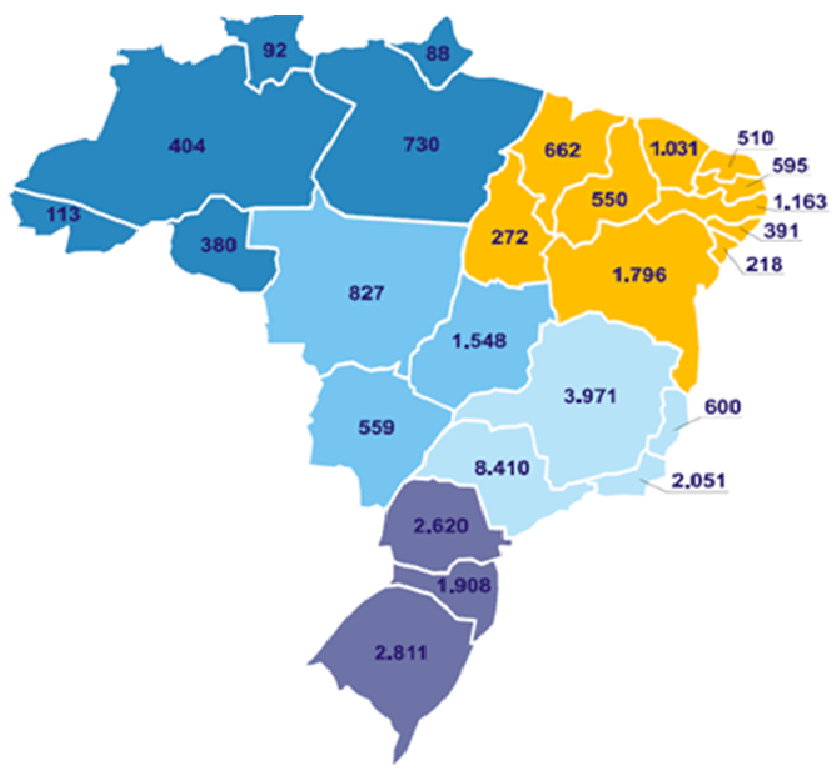

Figura 16 - Número de postos de venda de combustíveis no Brasil, por estado

Fonte: Sindicom, 2007 
A logística de combustíveis requer uma forma bastante apropriada para a escolha do modal de transporte do mesmo levando-se em conta condições de entrega e custo. Existem modelos diferentes para escolha dos modais, mas um deles que é bastante sintético e prático conforme Figueiredo (2005) apresenta, a escolha do modal depende essencialmente da distância entre os pontos de coleta e entrega da rota e o volume de carga a ser transportado. A figura 17 ilustra este modelo.

Em essência, este modelo contempla soluções com maior ou menor flexibilidade na entrega ( capilaridade, capacidade de absorção de variações de volume etc) e capacidade de diluição de custos fixos e investimentos de capital ( Capex). Caso a distância da rota seja pequena e o volume transportado também, o melhor modal a ser utilizado é o rodoviário, por conta de sua flexibilidade na entrega e com custos variáveis maiores. No entanto, no final das contas, devido à pequena distância percorrida, o impacto na estrutura de custo total é pequeno.

Não é por acaso que o fluxo de entrega de combustíveis, conforme figura 13, é feito $100 \%$ através de modal rodoviário no Brasil. Os demais modais para transporte de combustíveis ( ferroviário, aquaviário ou dutoviário ) podem ser utilizados nas situações em que a diluições de custos fixos e investimentos ocorrem de melhor maneira mas com menor flexibilidade no atendimento à demanda.

Nestes casos faz-se necessário o planejamento de investimentos e demanda no longo prazo para a viabilização de projetos e empreendimentos destes modais.

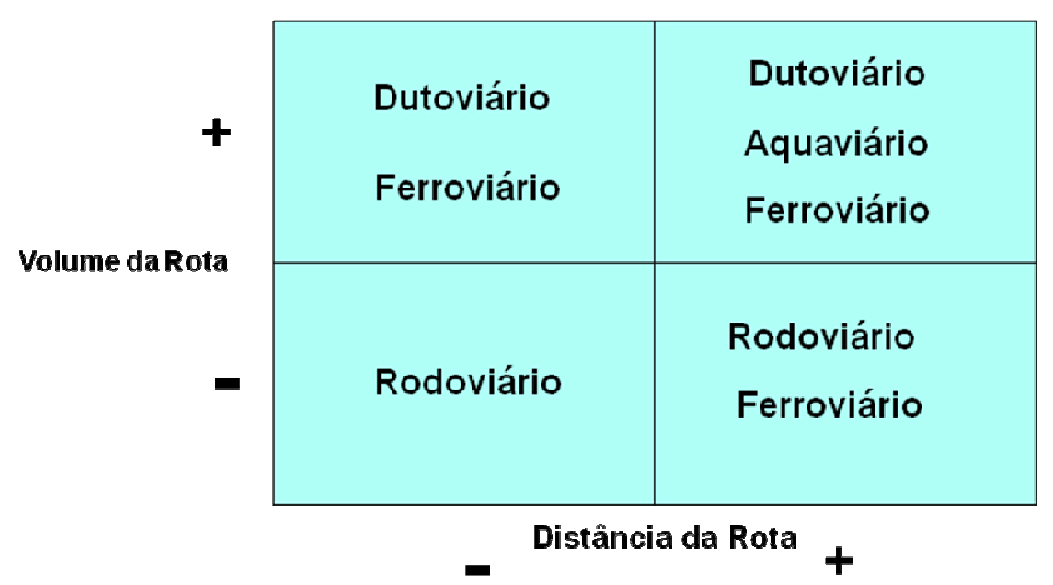

Figura 17 - Modelo conceitual - matriz de transportes

Fonte: Figueiredo , 2005 
Um aspecto também levantado no estudo de Figueiredo (2005) realizado junto a 30 entidades e empresas é a super utilização da malha rodoviária para transporte de combustíveis líquidos . A constatação é que transportes são realizadas pelas empresas do setor mesmo em distâncias superiores a $200 \mathrm{~km}$, algumas superiores a $500 \mathrm{~km}$. A conclusão é que a malha ferroviária, dutoviária e aquaviária existente no Brasil para o deslocamento dos combustíveis em distâncias maiores é insuficiente para as necessidades de transferência até as bases secundárias. Para as empresas do setor, estes deslocamentos de longa distância por modal rodoviário representam apenas $4 \%$ do volume total de entrega mas representam $20 \%$ do valor total de gastos.

Conforme estudo realizado por Figueiredo (2005), 75\% das rodovias nacionais estão em estado precário. Comprometendo a qualidade, cumprimento de prazos e custos na logística do etanol. Contudo o estudo argumenta que os investimentos previstos na infra-estrutura logística na época , para exemplificar, os investimentos ferroviários previstos da figura 18, poderiam minimizar os gargalos existentes .

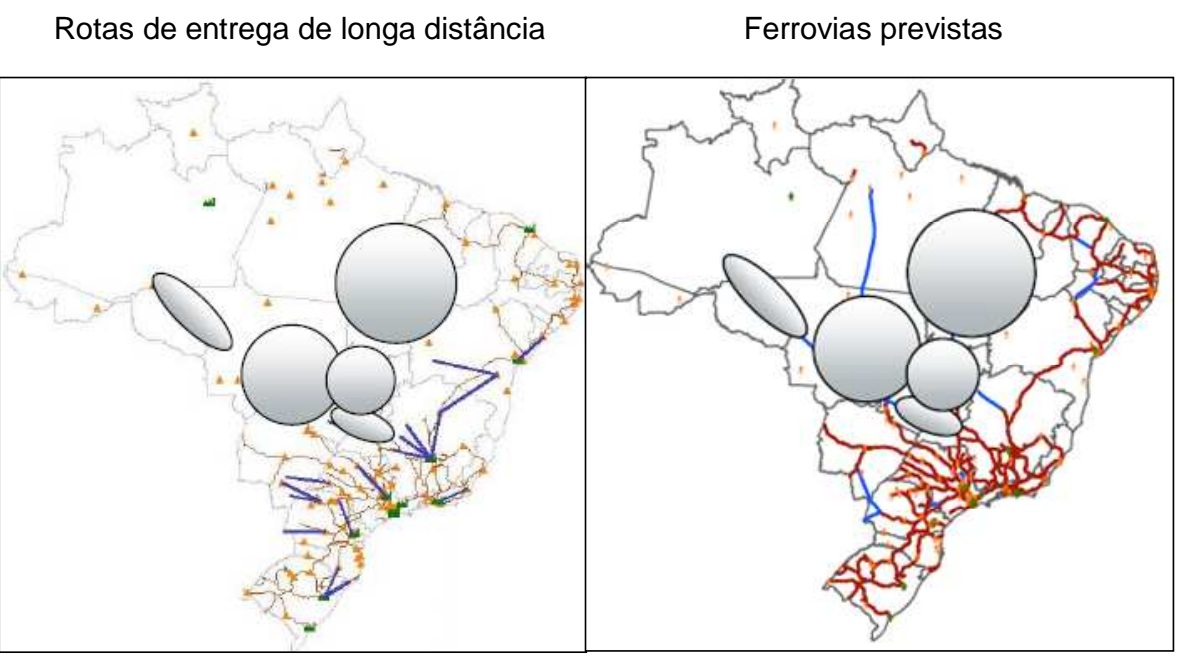

Figura 18- Rotas de entrega de longa distância de combustíveis e ferrovias planejadas

Fonte: Figueiredo, 2005

Um aspecto relevante no tocante à logística de distribuição é relativo à sazonalidade da cultura da cana-de-açúcar. Nos meses de entressafra, ou período de chuvas, que na região sudeste são os meses de verão . Neste período obviamente as condições para distribuição se tornam mais fáceis. Porém a dificuldade se encontra nos meses de safra quando sobrecarrega a distribuição do etanol. O fato é que a malha de distribuição consegue absorver estas oscilações, por experiência nossa e contatos informais. Porém os custos totais de distribuição 
se elevam por conta do custo de oportunidade dos agentes logísticos . As discussões entre representantes do setor sucroalcooleiro e do governo federal sobre a formação de estoques de reserva para equilibrar preços nas questões de safra e entressafra podem ajudar também a diluir custos no final da cadeia, inclusive as variações de custos oriundos da questão logística.

\subsubsection{Logística para exportação e modal dutoviário}

Uma forma de dividir a logística de distribuição do etanol é quanto ao abastecimento dos mercados internos e exportação. No caso da exportação, há de se considerar que, no Brasil, todo o fluxo logístico ( coleta , transferência e entrega ) deve ter o destino final os portos marítimos. Para viabilização econômica da exportação os volumes transportados devem ser significativos para os respectivos ganhos de escala. Lembrando ainda o processo de interiorização das produções de etanol faz com que a distância a ser vencida entre os pontos de produção e os portos marítimos seja significativa. Desta forma, a integração de modais de transporte, além do caro modal rodoviário, como o hidroviário, ferroviário e particularmente o dutoviário têm sido discutidos e investimentos têm sido realizados. Os portos marítimos no Brasil, por sua vez, carecem de investimentos nos últimos anos e seus ciclos de maturação são longos, vistos em muitos casos, como o maior gargalo na logística do etanol.

Um importante agente no contexto da exportação do etanol brasileiro é a empresa de capital misto Petrobrás, maior empresa do país, que tem se posicionado de forma bastante agressiva neste setor conforme discutido no item produtores de etanol do presente trabalho. Na questão logística a Petrobrás tem se colocado como player fundamental no país, seja como operador logístico, desenvolvendo e investindo em unidades de armazenamento e fluxos dutoviários cativos para o etanol ( em cooperação com empresas estrangeiras ) e também como trader viabilizando a exportação.

Conforme Colin et al (2009) o papel da Petrobrás no setor sucroalcooleiro é e será fundamental para garantir a sustentabilidade ( financeira particularmente) do setor dada a fragmentação de interesses e ações. Isto a despeito do potencial domínio no setor e a conseqüente preocupação por parte dos demais players deste mercado. 
A discussão envolve o modal dutoviário e sua importância para a logística de exportação. Uma primeira análise possível é a comparação entre as estruturas logísticas de dutos entre os 2 maiores países produtores de etanol: EUA e Brasil.

Conforme Figueiredo (2005) a estrutura de dutos do Brasil levando se em conta a extensão territorial do país e a extensão de dutos é bastante baixa. Em comparação aos EUA, é 24 vezes inferior. No entanto, quando comparada à vazão de combustíveis líquidos transportado, o perfil brasileiro ainda é quatro vezes inferior ao norte-americano porém já em um nível intermediário comparado a outros países conforme ilustra a figura 19.
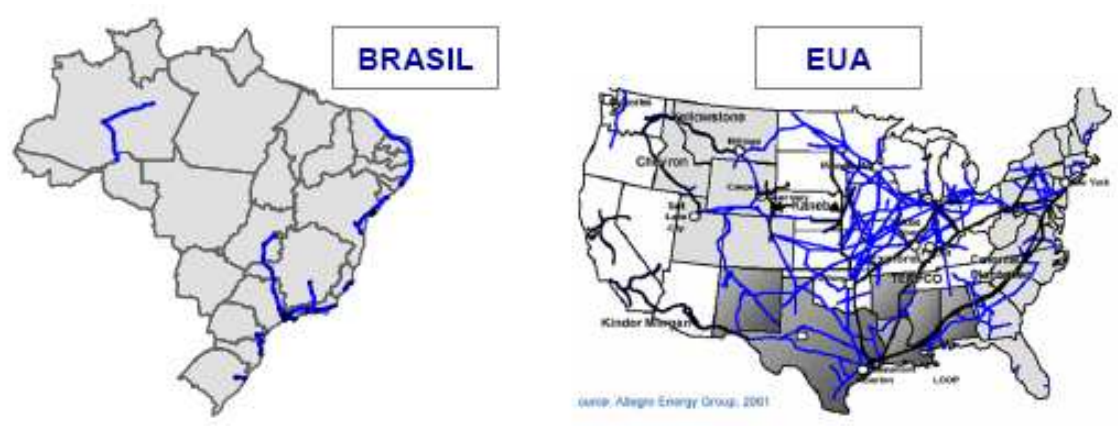

Análise considerando a extensão territorial

Análise considerando o volume de derivados comercializado

\begin{tabular}{|c|c|c|}
\hline Pais & $\begin{array}{c}\text { Dutos } \\
(\mathrm{Km})\end{array}$ & $\begin{array}{c}\text { Densidade } \\
\left(\mathrm{Km} / \mathrm{mil} \mathrm{Km}^{2}\right)\end{array}$ \\
\hline Brasil & 5.281 & 0,6 \\
\hline Suiça & 108 & 2,6 \\
\hline Alemanha & 2.370 & 6,6 \\
\hline Espanha & 3.779 & 7,5 \\
\hline Dinamarca & 330 & 7,7 \\
\hline Áustria & 777 & 9,3 \\
\hline França & 5.746 & 10,4 \\
\hline EUA & 146.426 & 15,2 \\
\hline
\end{tabular}

\begin{tabular}{|c|c|c|}
\hline Pais & $\begin{array}{c}\text { Volume (MM } \\
\text { m }^{3} \text { /ano) }\end{array}$ & $\begin{array}{c}\text { Razão (Km Dutos } \\
/ \text { mil } \mathbf{~ m}^{2} \text { Volume) }\end{array}$ \\
\hline Suiça & 13 & 0,01 \\
\hline Alemanha & 110 & 0,02 \\
\hline Dinamarca & 7 & 0,05 \\
\hline Brasil & 83 & 0,06 \\
\hline Austria & 11 & 0,07 \\
\hline França & 76 & 0,08 \\
\hline Espanha & 43 & 0,09 \\
\hline EUA & 608 & 0,24 \\
\hline
\end{tabular}

Figura 19 - Estrutura dutoviária brasileira e de países selecionados

Fonte : Figueiredo, 2005

Colin et al (2009) pondera que os perfis dutoviários nos EUA e Brasil são distintos, enquanto nos EUA não existem atualmente dutos específicos para o transporte de etanol, devido ao histórico disperso do setor nos EUA, no Brasil existem esforços significativos de projetos e investimentos em curso para a construção de dutovias próprias para o etanol.

A utilização de dutos para o transporte de líquidos envolve complexidade alta. Conforme Rejowski (2007), a utilização de dutos é o modo mais eficaz de transporte de grandes quantidades de fluidos líquidos e gasosos em grandes distâncias. E a necessidade de 
instalação de dutos se dá quando existe ou ao menos a previsão de demanda significativa e constante por longo prazo, pelo menos 20 anos. No entanto envolvem uma série de dificuldades Por exemplo sob o ponto de vista da operação, a necessidade de planejamento (schedulling) na utilização da capacidade do duto e consequentemente o atendimento à demanda e a otimização de custos de transporte.

No Brasil, as dutovias historicamente têm sido usadas para transporte de petróleo, seus derivados e gás natural. O uso para transporte de etanol ainda é irrisório conforme ilustra a tabela 12 .

Tabela 12 - Quantidade e extensão de dutos em operação, por função, segundo produtos movimentados, em 31/12/2008

\begin{tabular}{|c|c|c|c|}
\hline \multirow{2}{*}{ Produtos movimentad os } & \multicolumn{3}{|c|}{ Dutos em operação } \\
\hline & Função & Quantidade & Extensão (km) \\
\hline Total & & 547 & 16.986 \\
\hline \multirow[t]{2}{*}{ Derivados } & Transferência & 286 & 1.004 \\
\hline & Transporte & 102 & 4.849 \\
\hline \multirow{2}{*}{ Gás natural } & Transferência & 59 & 2.235 \\
\hline & Transporte & 31 & 6.838 \\
\hline Petróleo & Transferência & 32 & 1.985 \\
\hline \multirow[t]{2}{*}{ Outros $^{1}$} & Transferência & 32 & 36 \\
\hline & Transporte & 5 & 40 \\
\hline
\end{tabular}

Fontes: ANP/SCM, conforme a Portaria ANP no 170/1998.

'Inclui dutos para movimentação de álcool anidro, álcool hidratado, aguarrás e metanol, etano e propano de

insumo para petroquímica, gasolina de pirólise e propileno de insumo para indústria petroquímica.

Fonte: ANP, 2009

Com relação aos custos associados ao modal dutoviário, sob a ótica do operador logístico responsável pelo duto, os custos totais podem ser divididos em remuneração do capital investido para investimento na estruturação e montagem do duto e os custos operacionais. Dentro da questão dos custos operacionais existem os custos variáveis ( variam diretamente com a escala de produção e transporte, neste caso) e os fixos (independentes dos volumes transportados). O modal dutoviário é o que apresenta os maiores custos totais e fixos, necessitando assim de alta escala de utilização ( volumes transportados de combustíveis ) para a diluição destes custos. Com relação aos custos variáveis, destaca - se o custo da energia para o deslocamento dos fluidos ao longo do duto. E a energia utilizada é diretamente proporcional á capacidade de carga do sistema e ao diâmetro da tubulação. Conforme Andriolli (2009). 
Por estas características técnicas o custo da tonelada transportada por quilômetro diminui substancialmente em dutos maiores desde que haja processamento suficiente para justificá-los conforme Andriolli (2009) . O gráfico teórico apresentado na figura 20 ilustra a relação que existe entre custos de dutovias, vazão e diâmetro do duto.

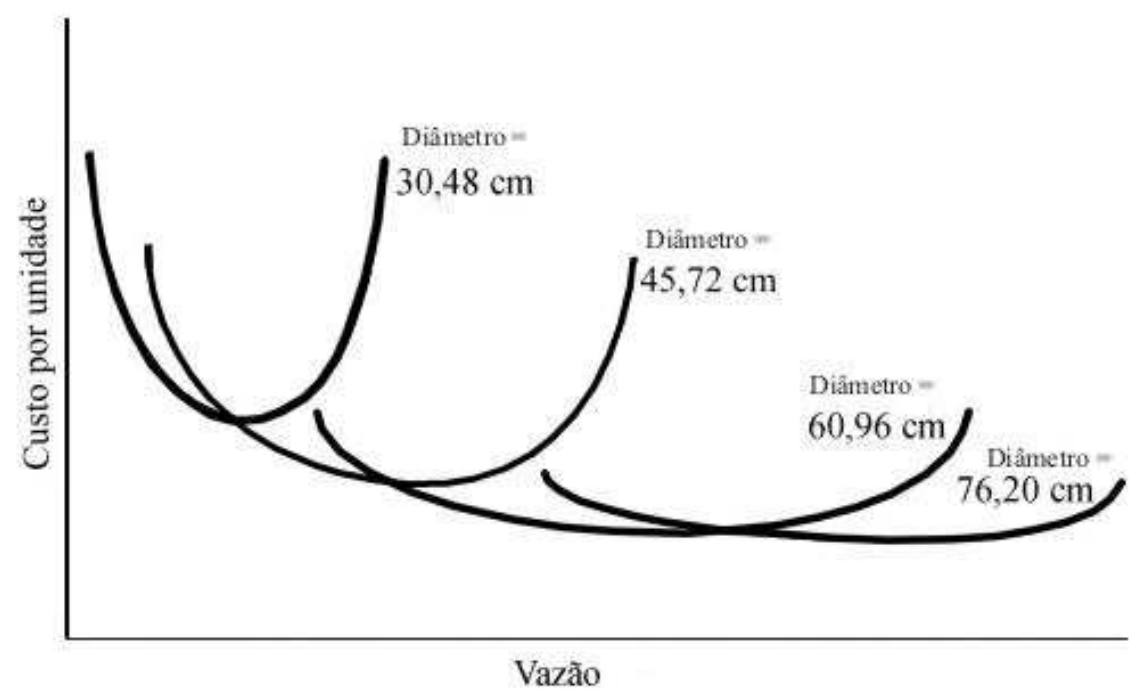

Figura 20 - Custos genéricos de dutovias em função da vazão e diâmetro do duto

Fonte: Andriolli , 2009 apud Ballou, 2006

Conforme Andriolli (2009), para se obter o pleno benefício do sistema dutoviário, há a necessidade de se operar em capacidade ótima, a qual pode variar conforme as características físicas de cada duto e pode ser determinada por curvas como a exemplificada na figura 21 .

Andriolli (2009) ainda salienta que o ponto mínimo de um determinado diâmetro não implica no custo unitário mínimo para cada quantidade, na medida em que existem intervalos de quantidades de escoamento em que são mais vantajosos outros diâmetros de duto. Desta forma, é fundamental avaliar no longo prazo as demandas históricas, na medida em que elas oscilam, para poder definir o melhor arranjo para a dutovia. Esta questão é determinante no caso do etanol por conta da sazonalidade deste combustível. 


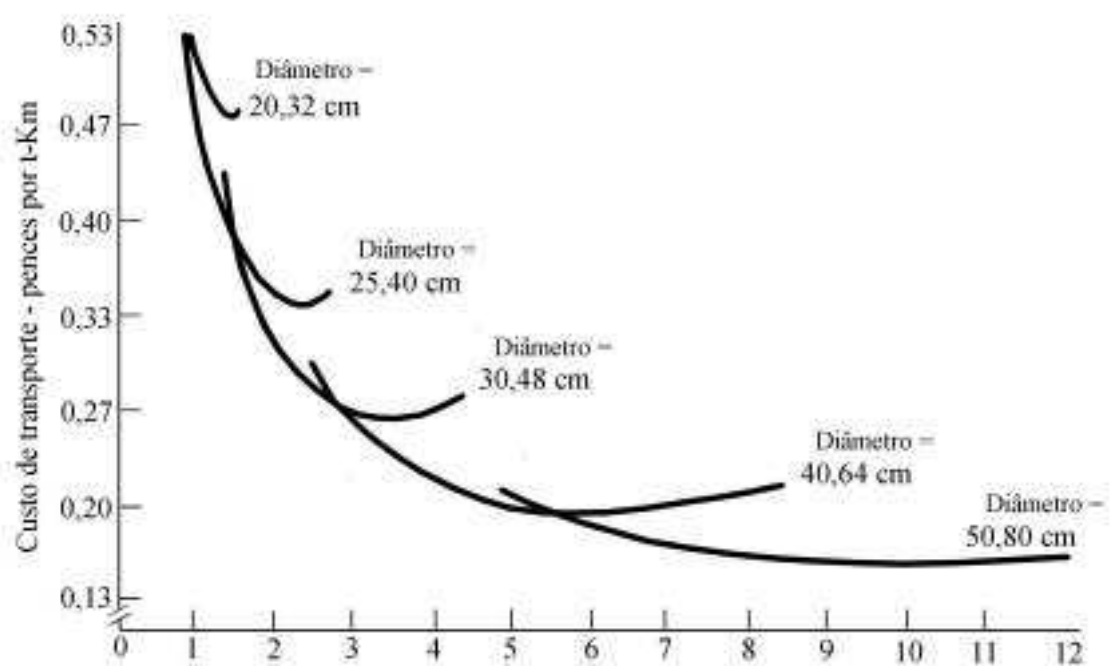

Figura 21- Relação entre quantidade transportada, diâmetro do duto e custos de transporte

Fonte: Andriolli, 2009

Vários investimentos têm sido planejados e realizados para dutovias para transporte de etanol com vistas á expansão e a garantia da exportação. E um agente fundamental neste contexto é o próprio governo brasileiro através do atual programa de aceleração do crescimento (PAC) que prevê a construção de dutovias e terminais aquaviários. A execução destes investimentos fica por conta da Petrobrás e suas afiliadas ( no caso a Transpetro) estimadas em R\$890 milhões até 2010 e mais R \$1,53 bilhão após este ano. (EPE, 2008).

O Programa Etanol denominado pela Petrobrás está dividido em 3 grandes áreas de interesse:

- Programa Corredor de Exportação de Etanol, que abrange as regiões Sudeste e CentroOeste;

- Projeto Exportação - Região Sul;

- Projeto Exportação - Região Nordeste

O Programa Corredor de Exportação de Etanol da Transpetro, localizado na região sudeste/Centro-Oeste, visa ampliar a capacidade de exportação do etanol produzido no oeste e noroeste de São Paulo, sul de Goiás e Mato Grosso. Conforme mostra a figura 21. A Transpetro realiza a análise de viabilidade técnico-econômica para a construção de um duto de aproximadamente 2.000 km interligando o Pontal do Paraná à Nova Olímpia, passando por Campo Grande e Cuiabá (trecho E da Figura 22). Com esse investimento, estima-se que a 
capacidade de exportação da região Sul deverá alcançar cinco milhões de m³/ano de etanol. Cabe destacar que o Porto do Pontal tem capacidade para navios de porte até $80.000 \mathrm{~m}^{3}$. ( EPE,2008)

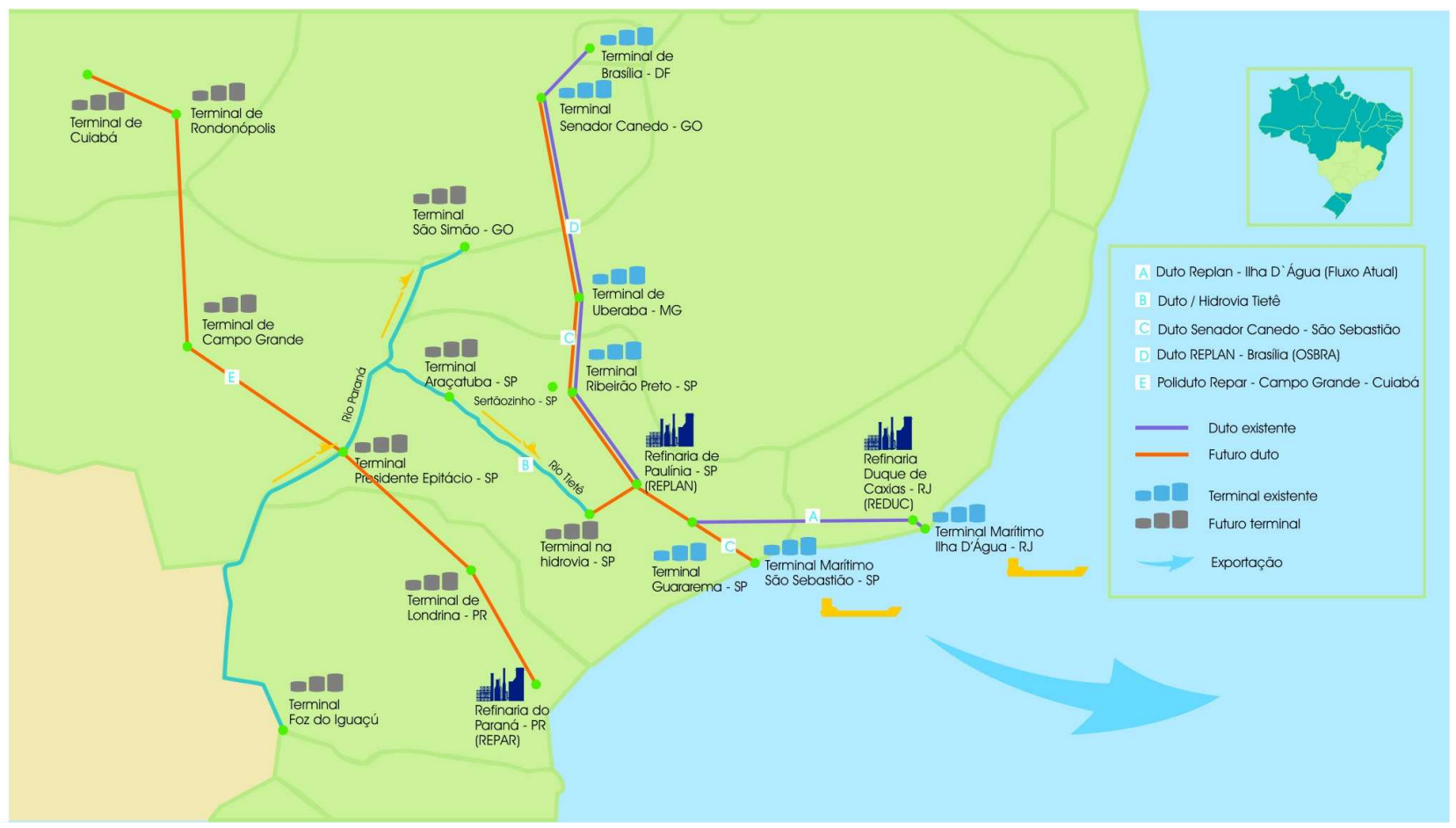

Figura 22 - Programa Corredor de Exportação de Etanol Sudeste, Centro-Oeste e Sul

Fonte: EPE,2008

A alternativa ao trecho (Pontal do Paraná à Nova Olímpia) em estudo pela Transpetro seria a extensão do trecho Senador Canedo - São Sebastião, em construção, a partir de Buriti Alegre passando por Jataí e Cuiabá, adicionando 945 km à malha, vide Figura 23. 


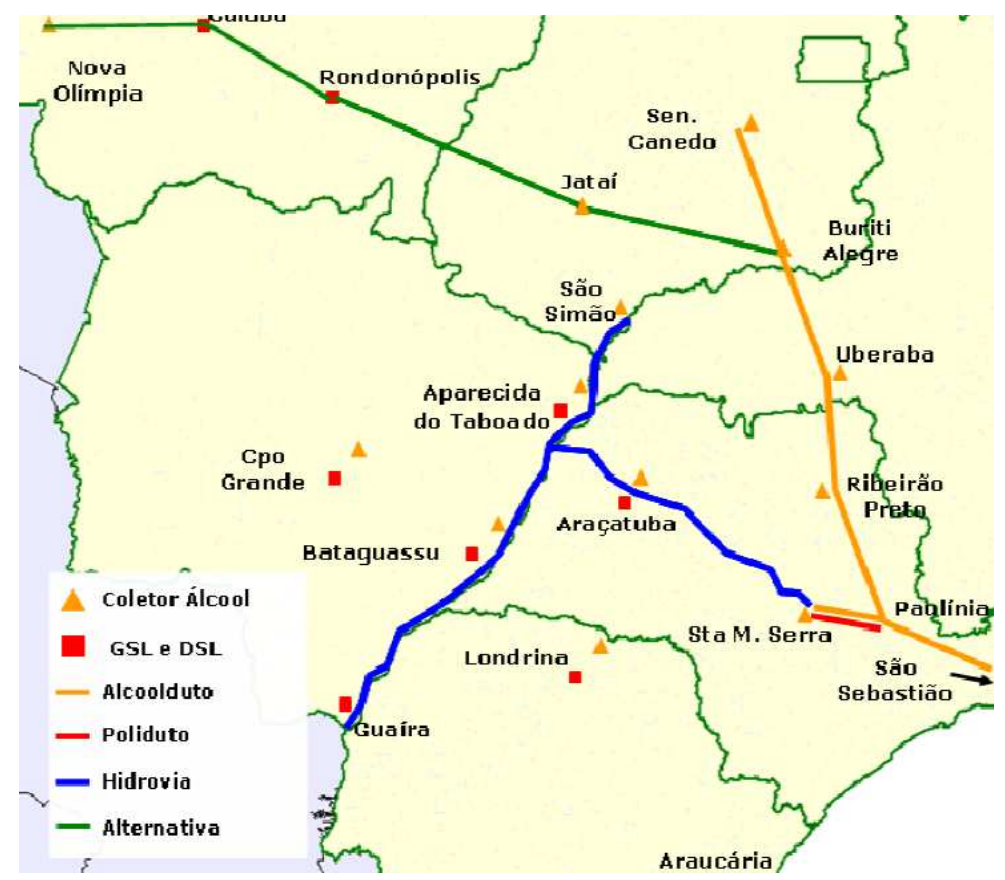

Figura 23 - Alternativa de escoamento Centro-Oeste Sul

Fonte : EPE,2008

Algumas empresas ou consórcios privados estão também investindo na construção de dutovias de etanol para exportação.

Brenco é uma empresa recentemente adquirida pela ETH do grupo Odebrecht, conforme item produtores de etanol do presente trabalho, planeja construir um sistema constituído de $1.120 \mathrm{~km}$ de dutos, partindo de Alto Taquari/MT para o Porto de Santos/SP, com capacidade de exportação de quatro milhões de $\mathrm{m}^{3} /$ ano e distribuição interna de dois milhões de $\mathrm{m}^{3} / \mathrm{ano}$.

O mesmo foi orçado em US\$ 1 bilhão e deve entrar em operação em 2011. Serão sete estações de bombeamento ( $23.392 \mathrm{hp}$ ) e seis terminais com capacidade de armazenagem total de 460 milhões de litros. A figura 24 ilustra o investimento. 


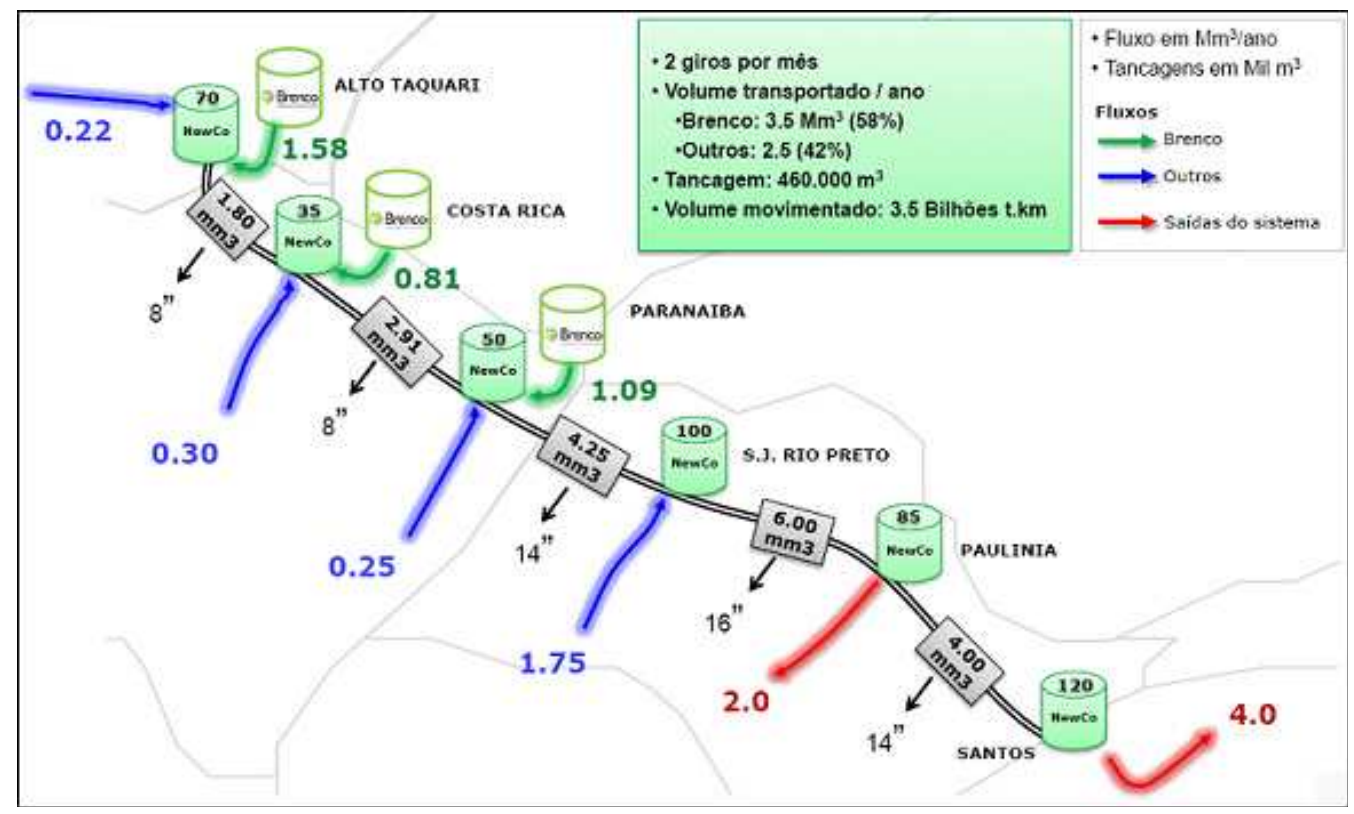

Figura 24 - Projeto dutoviário da empresa Brenco

Fonte EPE,2008

O projeto Uniduto foi formado por um consórcio de empresas do setor sucroalcooleiro dentre elas a Copersucar, Cosan, Crystalsev, Allicom entre outras. Os sócios juntos representam aproximadamente um terço da produção atual de etanol no Brasil, ou seja, 9 Bilhões de litros de etanol, produzidas nas 88 usinas do consórcio. E a estimativa é de que a maior parte da carga a ser escoada será dos próprios sócios do empreendimento ( UNIDUTO, 2009). O trecho Ribeirão Preto - Santos do empreendimento, com comprimento de $405 \mathrm{~km}$, contará com investimento de R\$1.6 Bilhão e a previsão de término é paras 2011 ( EPE,2008).

Os portos marítimos, por fontes informais apontados como um sério gargalo na logística de distribuição, vêm tendo também investimentos em projetos que buscam a expansão deste modal. Conjuntamente e perfazendo sistema integrado multimodal, segundo EPE, comporta atualmente o transporte de 3,6 bilhões de litros de etanol por ano envolvendo dutovia e ferrovias. Deste total, 2 bilhões se referem à capacidade da Transpetro ( subsidiária da Petrobrás ) e 1,6 bilhões de empresas privadas.

Os novos projetos de expansão dutoviária, conforme mencionado anteriormente, contemplam também investimentos em expansão portuária conforme figura 25 que poderão aumentar a capacidade de transporte portuário em 17,75 bilhões de litros anuais . 


\begin{tabular}{|c|c|c|c|c|}
\hline Região & $\begin{array}{l}\text { Terminal } \\
\text { Marítimo }\end{array}$ & $\begin{array}{c}\text { Capacidade } \\
\left(10^{6} \mathrm{~m}^{3}\right)\end{array}$ & Ano & $\begin{array}{l}\text { Custo } \\
\left(10^{6} \text { US\$) }\right.\end{array}$ \\
\hline Sudeste & Ilha D'Água & 4,00 & 2008 & \multirow{2}{*}{1.566} \\
\hline Centro-Oeste & São Sebastião & 8,00 & 2010 & \\
\hline Sul & Paranaguá & 5,00 & - & * \\
\hline Nordeste & Maceió & 0,75 & 2010 & 4 \\
\hline TOTAL & & 17,75 & & 1.570 \\
\hline
\end{tabular}

Figura 25- Novos projetos de expansão portuária - Transpetro

Fonte: EPE, 2008

Além destes projetos portuários oriundos do programa de aceleração do crescimento ( PAC) do governo federal, outros projetos privados vem sendo desenvolvidos como da Brenco e do consórcio Uniduto.

Quanto ao modal hidroviário, mais restritivo por natureza na medida em que só faz sentido à utilização dos meios fluviais propícios à navegação particularmente que cortam ou unem as regiões próximas á produção de etanol ( MS, GO, MT e norte do Paraná, principalmente ) aos grandes centros ou próximos ao litoral. A hidrovia Tietê-Paraná vem suprir exatamente esta demanda. A figura 26 ilustra a questão.

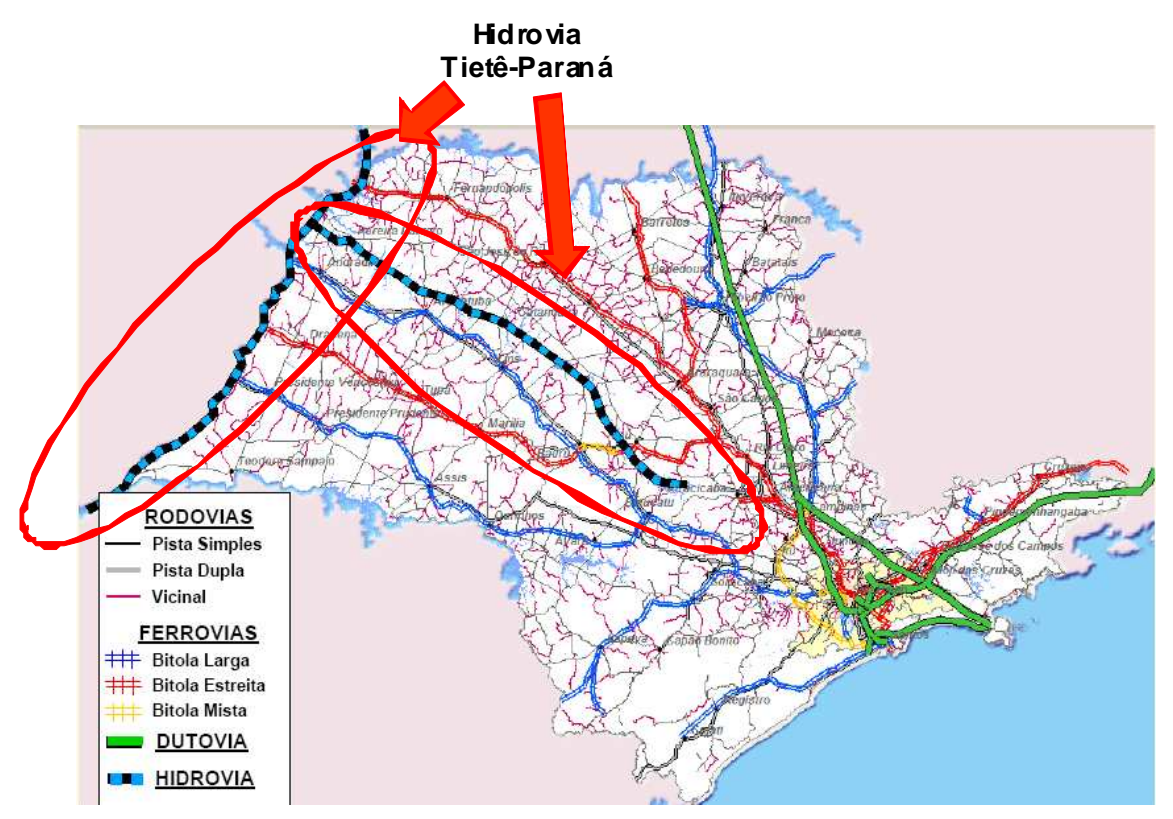

Figura26 - Ilustração hidrovia Tietê- Paraná

Fonte : Xavier,2007 


\section{DESENVOLVIMENTO}

\subsection{Modelagem da demanda de etanol e impactos na logística de distribuição}

A partir desta fase, a análise versará sobre os principais fatores, que denominados no presente trabalho condicionantes, que contribuem positivamente ou negativamente à expansão da demanda do etanol brasileiro. Da mesma forma, a discussão será de que forma estes condicionantes se inter relacionam, quando fizer sentido. Posto que seja fundamental o entendimento dos elementos que direcionam o crescimento, ou não, das necessidades de demanda do etanol.

Desta maneira, será possível avaliar as condições pelas quais a oferta no Brasil se dará, ou não, para atender tal demanda. Seguindo o raciocínio, poder-se-á ainda avaliar as necessidades, impactos e gargalos dos elementos que poderão garantir o atendimento á demanda com base nas características da oferta ( infra - estrutura, posicionamento e políticas públicas, logística etc ), conforme a figura 27. No presente trabalho avaliam-se os impactos na logística de distribuição do etanol ( para o mercado interno e externo).

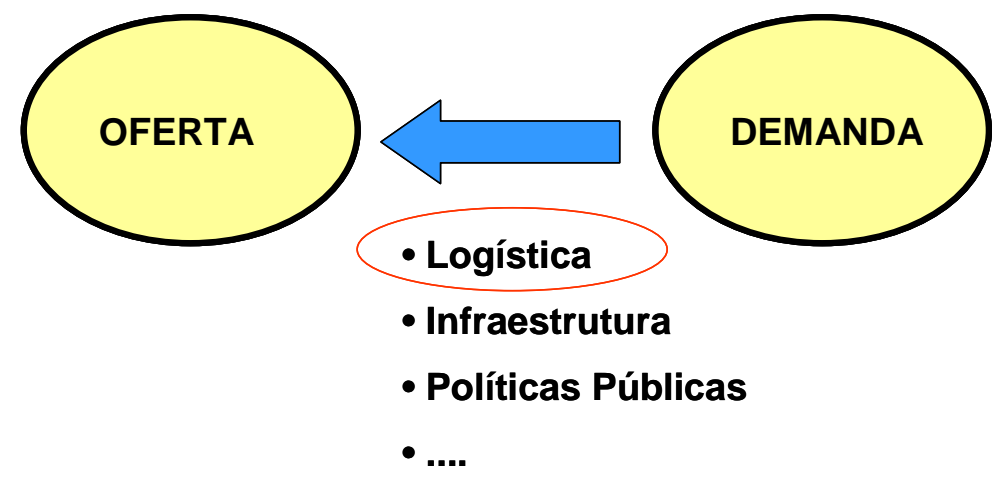

Figura 27 - Relação entre Demanda e oferta de etanol e necessidades

Fonte: autor 
3.1.1. Condicionantes para expansão da demanda do etanol e suas relações causais

Sob a ótica agregada dos condicionantes para a demanda do etanol e suas relações de causa e efeito, conforme figura 28, aqueles que diretamente direcionarão o crescimento da demanda ,ou não, do etanol no Brasil são a demanda interna e demanda para exportação.

A maior parte está direcionada ao mercado interno particularmente para prover o mercado de combustíveis de automóveis ( flex-fuel), que por sua vez dependerá do crescimento econômico do país e consequentemente o aumento de renda da população para compra ou troca de veículos novos. Dependerá ainda da relação de preço entre gasolina e etanol na medida em que os veículos flex-fuel podem optar pelos dois combustíveis e a opção é dada pelo preço. Por outro lado, existem ainda outros usos do etanol que irão gerar demanda, como são os casos das utilizações industriais e das bebidas alcoólicas.

Pelo lado da demanda para exportação, vários condicionantes atuam, sendo o principal deles é o protecionismo econômico através de taxações à importação do etanol estrangeiro ( no caso brasileiro) por parte dos principais países consumidores de etanol, notadamente EUA, Países europeus, Japão e China. O protecionismo se deve a vários fatores principalmente para o desenvolvimento das indústrias alcooleiras nestes países. Por conta disto, outro condicionante para a demanda do etanol brasileiro é a concorrência com outros biocombustíveis nestes países (álcool ligno-celulósico etc). Ainda na demanda para exportação, a estruturação de mecanismos de comércio internacional para o etanol favorecerão a comercialização do etanol (e não apenas o brasileiro) no mundo. Estes mecanismos passam pela padronização das características técnicas, mercados de longo prazo e mecanismos de hedge facilitariam a vida do setor sucroalcooleiro.

Todos os direcionadores citados previamente, da demanda interna ou da demanda para exportação são, em maior ou menor grau, influenciados por questões mais amplas: políticas, econômicas, sociais e ambientais. O posicionamento dos governos - tanto brasileiro quanto dos principais países consumidores é chave na facilitação, ou não, dos quesitos apresentados. Este posicionamento definirá políticas públicas sejam de subsídio, como no caso do protecionismo à importação dos países consumidores, sejam através de programas de fomento ao setor, por exemplo, incentivo para compra de carros flex-fuel no Brasil. Estas ações de governo estão obviamente relacionadas com as condições econômicas de cada país e as suas necessidades intrínsecas demandadas pelas populações, vide eleitores, aos seus representantes. 
Ainda em um nível mais alto, os direcionadores destas ações governamentais, se devem a forças do macro- ambiente. São elas, na nossa percepção: macro economia mundial que influencia e direciona riquezas e aumenta as necessidades energéticas dos países e força a tomar ações estratégicas para garantir seu suprimento. Ao mesmo tempo e em parte em decorrência do fator anterior, o esgotamento das fontes não renováveis de energia e seu conseqüente encarecimento. Ao mesmo tempo, existe também o avanço na conscientização das populações mundiais com respeito aos impactos ambientais do uso de fontes não renováveis, geradoras de gases de efeito estufa e poluidoras.

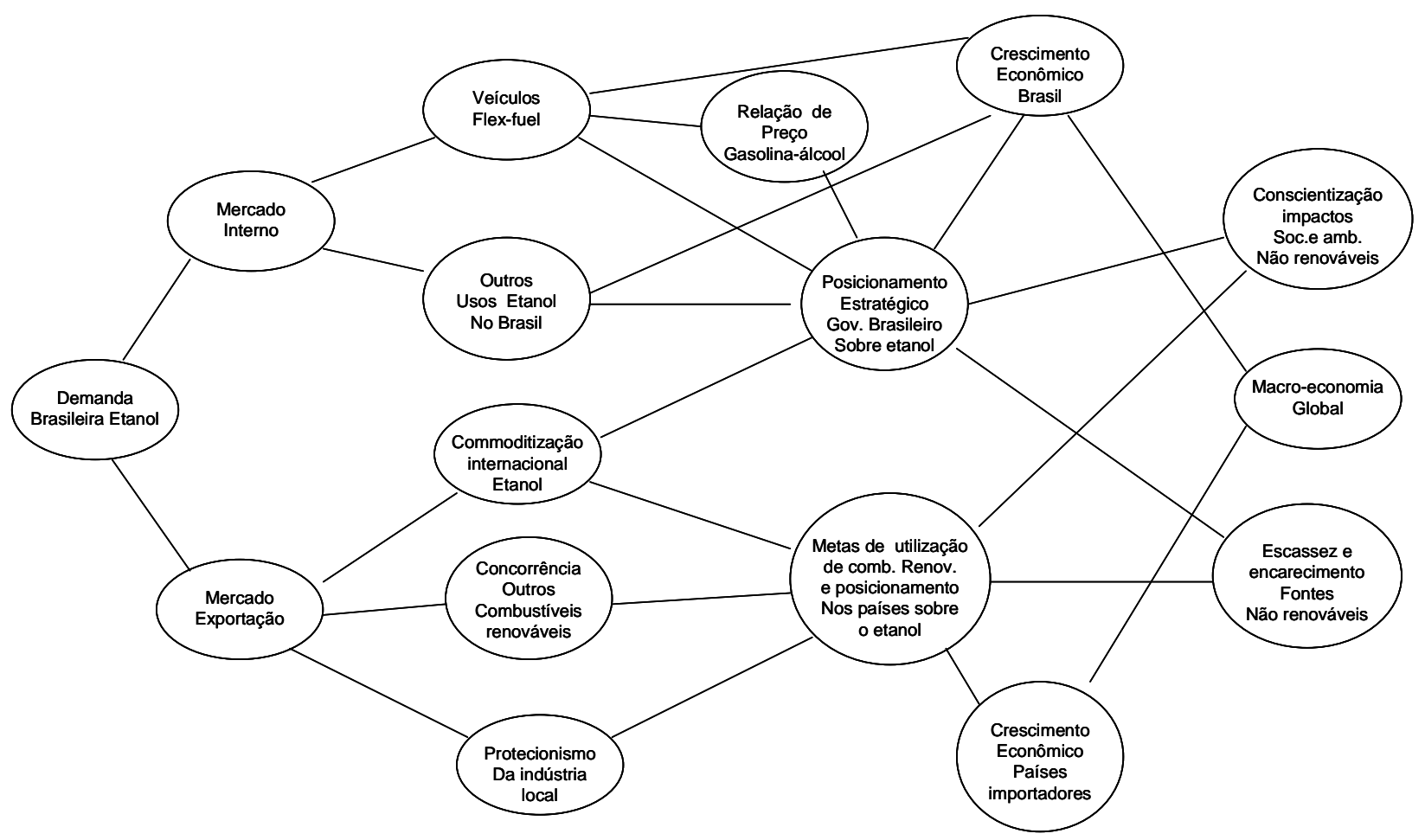

Figura 28 - Condicionantes da demanda do etanol no Brasil

Fonte: Autor

A seguir são discutidos aspectos sobre os condicionantes e mais especificamente sobre aqueles que mais diretamente ( ou proximamente) influenciam a demanda do etanol brasileiro.

O advento da cana-de-açúcar no Brasil conforme mostrado neste presente trabalho origina-se de longa data, desde o século XVI e as usinas de processamento no nordeste brasileiro. As condições climáticas favoráveis, extensas áreas agriculturáveis, regime de chuvas que permitem a cultura e, particularmente eventos sócio-político-econômicos que permitiram a expansão da cultura, em muitos momentos da história do Brasil, aos saltos. 
Mais especificamente no caso do etanol, as crises mundiais do petróleo na década de 70 e ações governamentais, por necessidade e visão, investiram na tecnologia do uso de etanol em automóveis e conseguiram transformar o Brasil em uma potência econômica e tecnológica em energia renovável. Conforme Jank ( 2009), desde Março de 2008 o consumo de etanol combustível é maior que o de gasolina para automóveis no Brasil. Em 2008, aproximadamente $91 \%$ dos automóveis vendidos no Brasil poderiam ser abastecidos por etanol ( flex fuel ) em detrimento dos veículos movidos à gasolina somente. Convém lembrar ainda que mesmo na gasolina "pura", $25 \%$ de sua composição em volume é etanol anidro.

É de se convir que o consumo de etanol no mercado interno, particularmente para uso como combustível de automotores será o principal direcionador para a demanda do etanol brasileiro nos próximos anos. Conforme tabela 10, aproximadamente 26,8 bilhões de litros de etanol foram produzidos no Brasil em 2008 . Neste mesmo ano, conforme UNICA (2009), foram exportados 5,8 bilhões de litros foram exportados, sendo que os restantes 21 bilhões de litros foram consumidos ou estocados no país. Isto representa $78 \%$ do total produzido em 2008. Como mencionado anteriormente a maior parte dos veículos produzidos no Brasil já é flex fuel.

No entanto, existe ainda um grande potencial de crescimento orgânico da frota de veículos brasileiros como um todo, dado o crescimento econômico e o aumento de renda per capita do país e o aumento do crédito para financiamento da compra de veículos. Existe ainda ao longo do tempo a substituição natural da frota dos veículos antigos, predominantemente movidos à gasolina por veículos flex fuel . Conforme Rodrigues, T. R. (2009), em 2009 a frota de veículos leves no Brasil é de aproximadamente 29,2 milhões de unidades, sendo que os veículos flex fuel e movidos a álcool somente representam 11,2 milhões ou $38 \%$ do total. As frotas de veículos movidos a gasolina e GNV ( gás natural veicular) representam 15,9 milhões de unidades ou $54 \%$ do total e 2,1 milhões ou $8 \%$ do total, respectivamente. À medida que as vendas de veículos novos movidos a etanol continuem ao longo dos anos os percentuais mudarão de forma favorável ao etanol.

Importantes condicionantes para o crescimento da demanda por etanol são o contínuo crescimento econômico do país e da renda da população e do crédito ao consumidor para financiamento da compra de veículos novos. 
Outro condicionante representativo é a atratividade econômica do preço do etanol na ponta do consumo ( relação $70 \%$ do preço da gasolina). Este quesito se relaciona diretamente a outro: o posicionamento estratégico da Petrobrás quanto ao portfólio de produtos, mais especificamente gasolina e etanol. Conforme mencionado anteriormente o preço da gasolina não varia diretamente com o custo de oportunidade de seu maior insumo: o petróleo. Desta forma, o preço final do petróleo pode afetar de forma independente das leis de mercado a atratividade do etanol e da própria gasolina.

Questões ligadas à capacidade de adaptação das usinas perante as variações de mercado, leia-se variações sazonais e cíclicas inerentes ao negócio do etanol e açúcar, bem como da consolidação do mercado de oferta de etanol em curso no Brasil, entende-se serem plenamente absorvíveis e circunspectas ao próprio mercado ( usinas, fornecedores e meios de distribuição). O processo de resposta às demandas e amadurecimento do setor tem se dado de forma natural e positiva. A crise mundial de 2008 pegou o setor sucroalcooleiro ( assim como outros setores também) na contramão do ciclo de investimento, justamente no momento que muitas novas usinas entravam em operação, ou estavam próximas de, escasseou e encareceu se o crédito para financiamento de curto ( capital de giro) e longo prazos ( greenfields etc). Aliado a isso, tiveram um excedente de produção, a safra de 2008 foi recorde, conforme IBGE (2009) a safra foi 27,3\% em termos monetários que 2007, mas a demanda particularmente para exportação, definhou. Sem ainda uma política clara governamental de estoques reguladores, até porque o setor passa ainda por evolução não só de gestão empresarial e também holístico, envolvendo o posicionamento governamental setorial, os preços do etanol despencaram comprometendo ainda mais a lucratividade do setor. Usinas tiveram sérios problemas de caixa e capacidade de honrar compromissos financeiros e algumas até entraram em processo de recuperação judicial. Isto fez com que ativos se tornassem "baratos" e tem propiciado a aceleração da consolidação do setor através da aquisição das empresas deficitárias pelas mais saudáveis financeiramente.

Ainda para reforçar que a volatilidade do setor, após o excedente de oferta pela safra recorde de 2008, em 2009 ocorreram chuvas muito acima da média no Brasil comprometendo tanto a colheita da cana, na medida em que a chuva prejudica a produtividade das máquinas colheitadeiras, quanto o teor de sacarose na cana. Estes fatores serviram para o alerta de possível desabastecimento de etanol no mercado. Inclusive o governo federal reduziu o percentual de etanol na gasolina de $25 \%$ para $20 \%$, conforme Globo (2010). 
Fontes variadas afirmam que a partir de 2009 e 2010 os lançamentos de novas usinas será menor do que o ocorrido nos anos anteriores, porém continuará existindo por conta da perspectiva de crescimento da demanda. Isto posto indica que os envolvidos diretamente no setor sucroalcooleiro (produtores, usineiros, fornecedores e meios de distribuição e logística) tem se adaptado em maior ou menor grau às oscilações e com tempo de resposta adequado ao atendimento da demanda crescente.

No entanto, uma condicionante para o atendimento da demanda do etanol, exógena ao setor, porém envolvida, é o posicionamento e a atuação governamental brasileira no que se refere à estruturação de mecanismos e controles que auxiliem a minimização de riscos de comercialização e acomodem as oscilações demasiadas de oferta e demanda.

Não existe melhor exemplo do que a falta destes mecanismos pode acarretar no setor como o da crise mundial de 2008 como mencionado anteriormente. Em termos práticos, ações que poderiam ser feitas neste sentido e tem sido discutidas junto ao governo brasileiro pelos representantes do setor sucroalcooleiro são:

- A definição de políticas claras para estoques reguladores buscando homogeneizar um pouco o perfil extremamente sazonal da oferta de etanol, sem as quais comprometem margens e retorno aos investidores nos momentos de excedente de produção e, ao mesmo tempo, pode gerar falta de produtos e encarecimento ao consumidor nos momentos de entre safra.

- A estruturação e criação de mecanismos e novos atores na comercialização do etanol. O etanol brasileiro basicamente é vendido no mercado spot, nas condições momentâneas dos eventos de compra e venda. A inserção de mecanismos que propiciem contratos de médio e longo prazos e que possibilitem a comercialização de títulos destes contratos e a inserção de brokers, regulando seus papéis e responsabilidades obviamente auxiliarão os agentes do setor a minimizarem riscos e exposição devido à oscilação de oferta e demanda. Como isto, poder-se-á, na prática, gerar mecanismos de hedge para as usinas, aumentando ainda mais o interesse de novos investidores no setor. Por enquanto, os mecanismos existentes ainda são pouco representativos conforme ilustra gráfico da figura 29. 


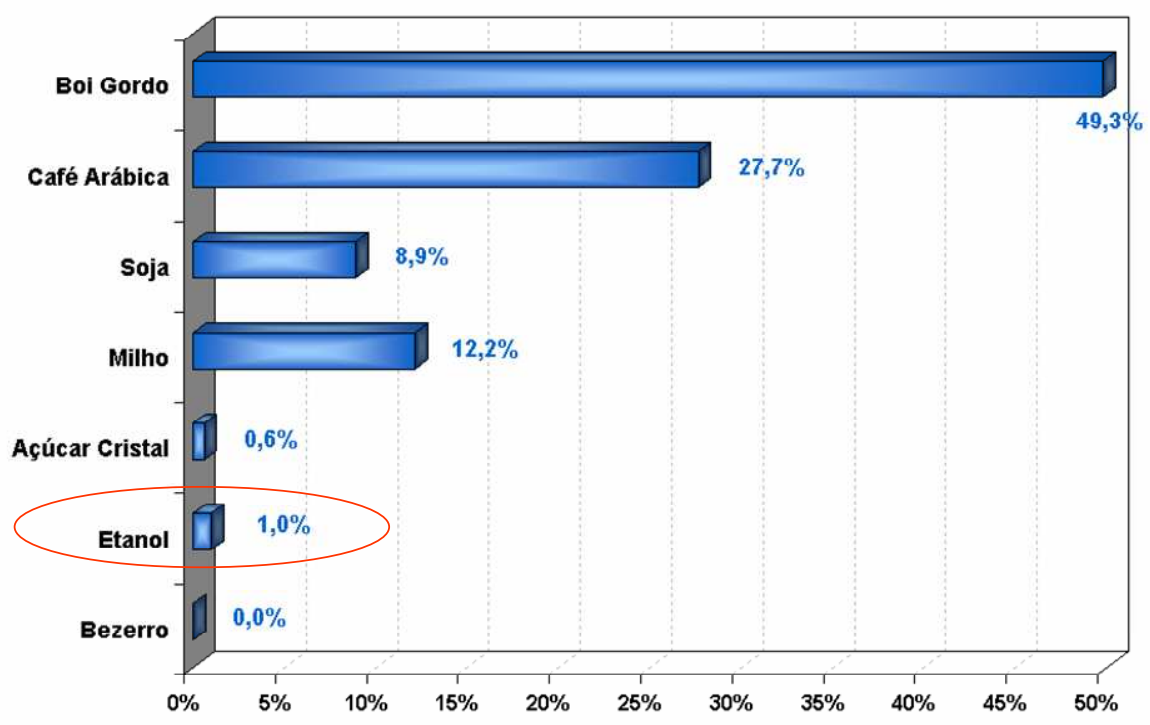

Figura 29 - Participação por commodity no mercado futuro brasileiro, 2008

Fonte: BM\&F BOVESPA, 2008

Entende-se, por outro lado, que o posicionamento governamental quanto à interferência nos mercados, o entendimento quanto à auto regulação é uma visão de governo e deve estar atrelada ao plano de governo e seus projetos estratégicos. De qualquer forma, o que se procura expor e reforçar no presente trabalho são as condicionantes para a demanda do etanol brasileiro. Ao mesmo tempo, a estruturação de um setor em franco desenvolvimento, como o caso do setor sucroalcooleiro, não acontece de forma linear, nem o posicionamento dos atores ocorre homogeneamente no tempo e no espaço.

A questão ambiental- social relativa ao possível desmatamento de áreas preservadas por conta da criação de novos locais para plantação de cana-de-açúcar, por sua vez, tem papel extremamente relevante quanto ao futuro do etanol brasileiro na medida em que cria perspectiva do etanol brasileiro particularmente para exportação. A questão ambiental-social, enquanto condicionante para a expansão do etanol, envolve outros aspectos como a possível utilização de mão-de-obra direta nas colheitas de cana em condições de semi escravidão, as queimadas das folhas da cana nas plantações para facilitar o corte e colheita da cana e consequientemente a emissão de poluentes e gases que favorecem o efeito estufa ( $\mathrm{CO} 2)$.

Porém o correto endereçamento por parte das entidades ( representativas do setor e governamental) enquanto comunicação, esclarecimento e ação pragmática sobre possíveis focos de abuso ambiental e social, tem no entendimento deste trabalho auxiliado para 
minimizar os efeitos desta condicionante negativa para expansão da demanda do etanol. Estudo realizado por Silva (2009) sobre balanço de energia e emissão de gases de efeito estufa (GEE) do etanol no Brasil avalia alternativas sobre possíveis ações para minimização destes efeitos. Os resultados destas análises demonstram potencial significativo de redução destes efeitos. As ações contemplam, por exemplo, a substituição do combustível utilizado para transporte de cana e a substituição de diesel por etanol e tem efeitos variados dependendo da região em que se atua ( interior paulista, centro oeste etc).

Assim o trabalho atual elucida alguns aspectos importantes da questão ambientalsocial, mas não integra no desenvolvimento do modelo de cenários para expansão do etanol.

Conforme mencionado no item 2.2.1, a produção do etanol tem crescido em média 10,9\% ao ano nesta última década no Brasil, suportado pelo investimento e expansão por empresas privadas na construção de novas usinas e campos para plantação de cana-de-açúcar.

No Brasil, o maior estado produtor de cana-de-açúcar é São Paulo, na safra 2005/2006 representou aproximadamente $63 \%$ da produção nacional de cana no país. Porém, a expansão da cultura da cana-de-açúcar tem sido direcionada a outros estados notadamente nas regiões centro oeste ( Goiás e Mato-Grosso do Sul) e sul ( norte do Paraná) que oferecem condições favoráveis ao plantio da cana-de-açúcar. O avanço do etanol para o interior do Brasil gera a preocupação quanto à invasão das plantações em áreas nativas e protegidas como a floresta amazônica. Estudos têm mostrado a importância da preservação da floresta amazônica, não só pela manutenção do bioma em si, mas pelos possíveis impactos no clima mundial e seqüestro de CO2 ( mata nativa versus culturas agropecuárias) (BUAINAIN et al, 2008).

A "interiorização" do plantio da cana, ou seja, cada vez mais usinas buscarem novas fronteiras para produção de cana com terras baratas, no entanto, não se viabiliza por conta do baixo potencial para produção de etanol ( qualidade, relevo e regime de chuvas ) A figura 30 ilustra os melhores locais para a produção de cana no País. 


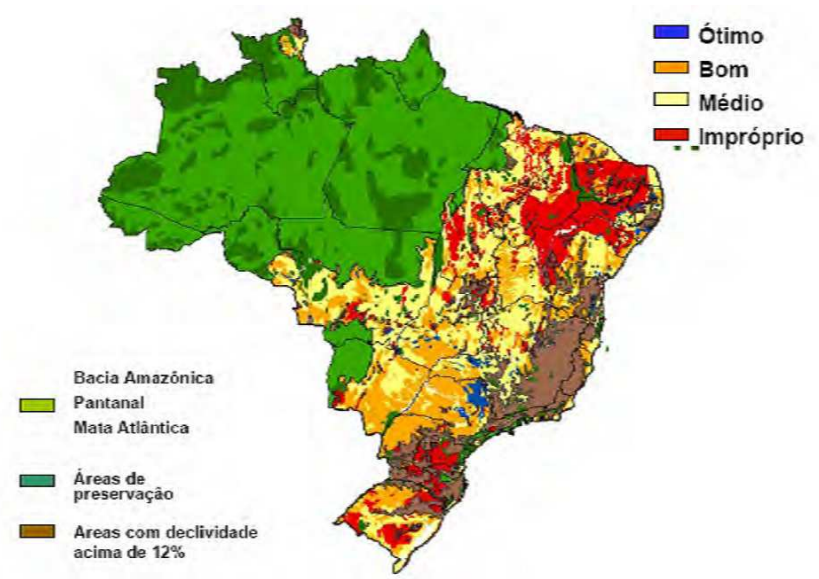

Figura 30- Potencial para plantação de cana de açúcar sem irrigação

Fonte : fórum nacional de bioenergia

Ao mesmo tempo, conforme UNICA( 2009), o zoneamento agrícola ecológico do governo brasileiro impõe proibições ao plantio em biomas sensíveis como a Amazônia e Pantanal e a expansão da cultura em áreas de vegetação nativa , por exemplo o Cerrado. Autoriza, por outro lado a plantação da cana em 64,7 milhões de hectares ou 7,5\% do território brasileiro, conforme mostra a figura 31. Atualmente por volta $0,9 \%$ do território nacional é ocupado pela plantação de cana-de-açúcar.

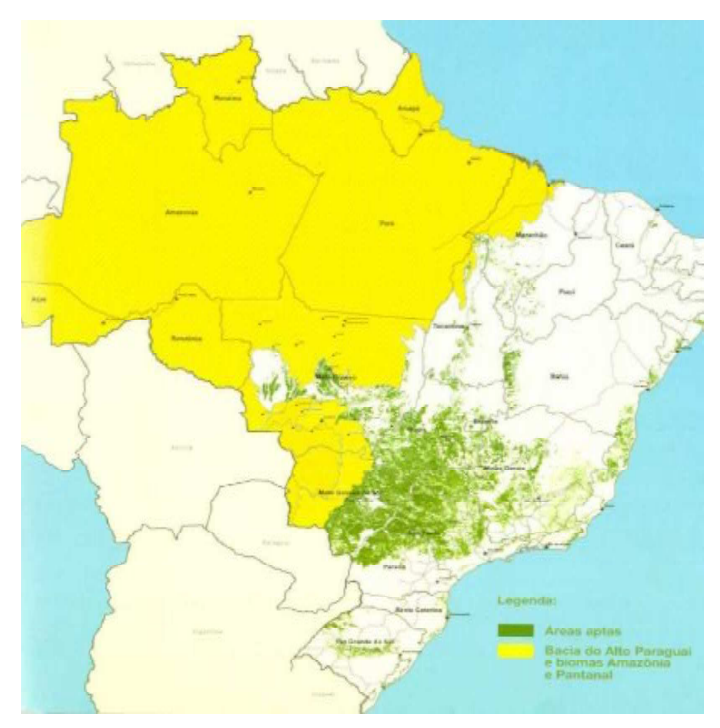

Figura 31 -Zoneamento do plantio da cana-de-açúcar

Fonte: UNICA, 2009

Por outro lado, o avanço da fronteira agrícola na Amazônia pode se der não pela canade-açúcar diretamente mas pelo deslocamento de outras culturas já existentes particularmente em Matogrosso e Goiás, essencialmente soja e algodão . Na região centro oeste nos últimos anos realmente houve desaceleração do avanço das culturas agrícolas em biomas naturais, 
mais pelas dificuldades financeiras das culturas mencionadas ( algodão e soja) que pela questão ambiental.

Desta forma o avanço da cultura da cana-de-açúcar na região centro oeste pode claramente deslocar as demais culturas, incluindo a pecuária, para a Amazônia. Neste caso, faz-se necessário o aumento do controle e fiscalização governamental bem como a busca de soluções integrativas ( sistemas de integração lavoura - pecuária) que busquem o aumento da produtividade conforme Buainain et al ( 2008 )

Outra condicionante relevante á expansão do etanol brasileiro a base de cana-deaçúcar é a concorrência de outras fontes avançadas de etanol ( que não consideram o etanol atual de beterraba, milho etc ) como o etanol ligno-celulósico, também conhecidos de etanol de segunda geração.

No entanto, estas fontes avançadas de energia estão em processo de desenvolvimento científico mas não em escala industrial . Desta forma existem percepções diversas sobre o impacto futuro do etanol de segunda geração sobre o atual etanol de cana-de-açúcar.

Conforme cita Goldemberg ( 2009, p.11): “[...] eu duvido que haja produção em larga escala desse etanol dentro de,pelo menos, dez anos. Daqui até lá, e por muito mais tempo ainda, o mundo todo tem condições de se beneficiar do etanol de cana-de-açúcar [...]"

De qualquer forma, parece ser consistente inferir que tanto o etanol de primeira e segunda gerações terão espaço na demanda mundial de energia. Fontes alegam que o etanol de primeira geração também está em processo de evolução tecnológica e de aumento de produtividade. Ao mesmo tempo, a tecnologia de etanol celulósico também poderá ser utilizada na cana-de-açúcar aproveitando das palhas, que atualmente são desperdiçadas, e eventualmente parte do bagaço de cana.

As principais novidades tecnológicas estão na bioquímica do etanol. As inovações mais radicais na produção de etanol com base nos materiais lignocelulósicos envolvem modificações genéticas de microrganismos que produzem enzimas que digerem a celulose e a hemicelulose encontradas na parede celular da planta, bem como variedades transgênicas de plantas mais produtivas.

Quando chegarem ao mercado, serão capazes de revolucionar os processos produtivos existentes ao usarem matérias-primas com disponibilidade quase ilimitada e quase sem valor, definindo um eventual novo paradigma tecnológico e a abertura de um leque de trajetórias 
tecnológicas para produção de energia, combustíveis e produtos químicos conforme Bastos (2007).

Por enquanto, no estágio atual de desenvolvimento os custos associados à produção ainda são muito altos. A Tabela 13 faz um comparativo dos custos e características do etanol de milho norte americano e o etanol celulósico em desenvolvimento.

Tabela 13 - Quadro Comparativo das Características Atuais da Produção do Etanol Celulósico e do Milho nos EUA

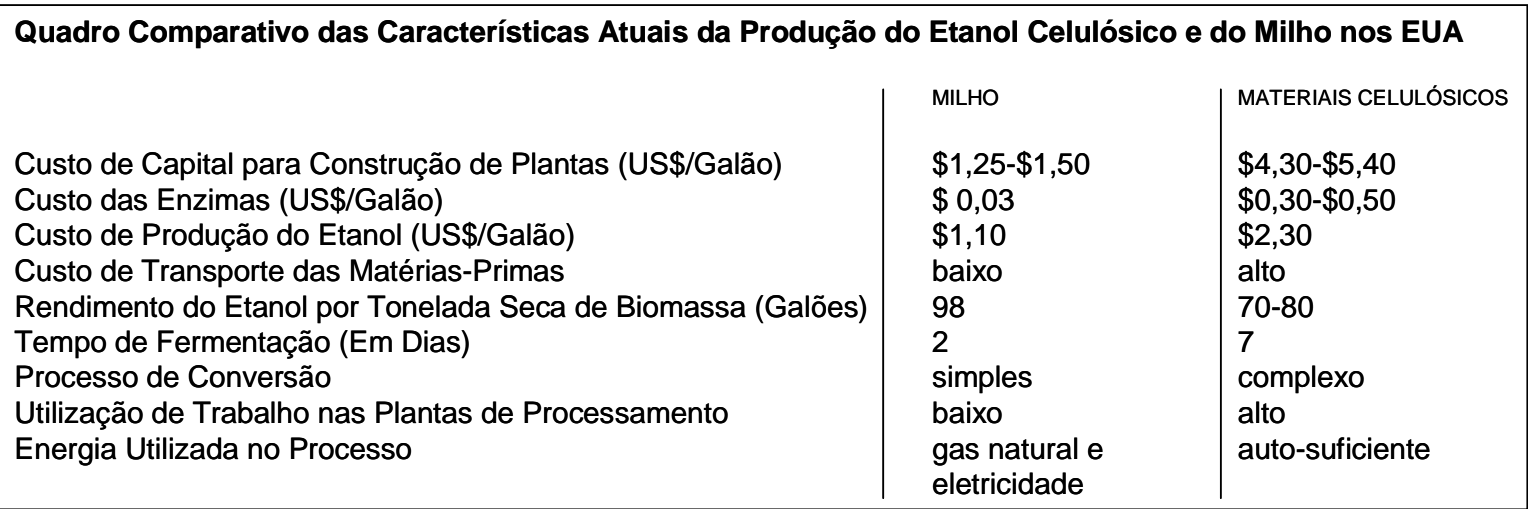

Fonte: Bastos,2007

O último grande condicionante para a expansão da demanda do etanol de cana-deaçúcar, no nosso entender, é a abertura progressiva dos mercados internacionais, particularmente EUA, Comunidade Européia, Japão e China, ao etanol brasileiro.

Conforme explorado no presente trabalho nas questões referentes aos principais mercados do etanol brasileiro, estes países, em maior ou menor grau, têm definido e evoluído mandatos para a utilização de combustíveis oriundos de fontes renováveis e limpas em detrimento de fontes poluidoras e não renováveis. No entanto, esta é uma questão extremamente complexa, na medida em que envolve interesses aspectos políticos, econômicos e sociais de cada país.

Um aspecto bastante relevante é a atitude protecionista dos governos com relação às cadeias produtivas de etanol de cada país através de taxações às importações do etanol brasileiro. Conforme já foi exposto no presente trabalho, o etanol brasileiro no atual estágio de desenvolvimento, possui ampla superioridade com relação aos custos de produção em comparação ao etanol produzido a partir de outras fontes agrícolas. 
Conforme argumenta Goldemberg (2009 p.14): “[...] sem esses obstáculos, o etanol brasileiro rapidamente vai tomar conta do mundo. Ele é muito mais eficiente. Isso, necessariamente, irá acontecer, mas é natural que, por questões comerciais, sobretudo, e políticas, os países desenvolvidos coloquem esses empecilhos [...]"

Além dos empecilhos à importação, são oferecidos subsídios aos produtores locais pelos governos. É um aspecto natural para o desenvolvimento da indústria alcooleira nos países. Assim como foi, por exemplo, o subsídio ao álcool no Brasil durante o período do programa Proálcool.

No entanto, alguns fatores podem antecipar a maior importação de etanol brasileiro. $\mathrm{O}$ primeiro relaciona-se ao alcance das metas cada vez mais agressivas dos países na substituição de combustíveis fósseis por renováveis conforme mencionado anteriormente.

Dificilmente os países conseguirão garantir o abastecimento da demanda por eles mesmos com suas ofertas locais. Requererão assim aumento no percentual de importações na demanda total.

O outro elemento se refere à atual crise econômica pós 2008. Crise esta que tem assolado o mundo e, coincidentemente, afetou significantemente os países que são os potenciais grandes importadores do etanol brasileiro, com exceção da China. A utilização de taxações às importações de produtos mais eficientes e subsídios às cadeias produtivas locais protegem e auxiliam o desenvolvimento e amadurecimento setorial nos países. Visam assim desenvolver tecnologia e conhecimento e gerar riqueza e outras externalidades positivas no longo prazo.

No entanto, estas ações geram déficits financeiros nos países no curto e médio prazos. Por conta da crise global de 2008, os países direcionaram recursos e se endividaram para socorrer os sistemas financeiros, crédito ao consumo e outros setores estratégicos.

As lideranças governamentais têm sido bastante pressionadas pela opinião pública, e provavelmente serão cada vez mais, para solucionar estas questões e garantir o bem estar da população. Assim, é de se esperar disputas cada vez mais acirradas, e questionamentos também, dos incentivos e uso de recursos para setores individualmente, como é o caso do etanol.

A dificuldade em conseguir e manter incentivos no setor nestes países se tornará cada vez maior e o sucesso ou não destas empreitadas dependerá da capacidade de negociação e da importância estratégica dada ao tema em cada país. Nos EUA são concedidos atualmente como subsídios ao etanol de milho norte americano por volta de US\$5 Bilhões anuais. Questão esta muito discutida e combatida atualmente pela indústria alimentícia que concorre 
diretamente com a do etanol. Ainda nos EUA, conforme UNICA (2010), a manutenção norte americana na taxação à importação ( US\$0,54 o galão) do etanol brasileiro está se tornando cada vez mais difícil, justamente por conta das pressões de vários setores.

De qualquer forma, entende-se que no presente contexto, a possibilidade de aumento das importações de etanol brasileiro nestes países tende a se acentuar.

Um fator que vai em direção contrária á demanda do etanol brasileiro, apesar de que no todo também ser positivo ao Brasil, é a exportação da tecnologia de produção de etanol a outros países. Por um lado o Brasil ganharia vendendo conhecimento, pois esta venda geraria muito valor agregado, mas perderia na produção de etanol e outros países passariam a produzir e competir em melhores condições com o nosso etanol. Por enquanto, o que parece é que estes possíveis impactos ainda são distantes no horizonte de planejamento, portanto não são considerados como um condicionante á demanda do etanol no trabalho atual. No entanto, poderá vir a ser em função da evolução do posicionamento brasileiro enquanto vendedor e franqueador da tecnologia de produção do etanol.

\subsubsection{Cenários de expansão da demanda e análises}

A partir desta fase avaliações de possíveis cenários de expansão da demanda do etanol no Brasil são trabalhados, com base em hipóteses dos principais condicionantes para a expansão da demanda e suas possíveis implicações sobre a necessidade de infra-estrutura logística. São tomados como base dois grandes cenários para análise:

- Cenário Realista

Como base em estudos e cenários realizados por diversas fontes de informação (empresas, órgãos governamentais etc ). Utilizado particularmente o estudo realizado pela EPE ( 2008), o qual, são feitos ajustes metodológicos. Este cenário vislumbra sob a ótica realista pois serve de base para as posicionamentos e investimentos reais de empresas privadas e pública. Considera-se também a perspectiva de crescimento e das necessidades de investimento.

- Cenário otimista

Toma como bases o potencial total de crescimento da demanda do etanol brasileiro. Obviamente tornando o perfil de crescimento mais acentuado gerando implicações e gargalos logísticos de forma mais acentuada. Assim permitindo análises de sensibilidade. 
Não são considerados um possível cenário pessimista no presente estudo, isto é, a manutenção de demanda nos níveis atuais ou mesmo a diminuição da demanda do etanol, na medida em que as implicações para a necessidade de infra-estrutura logística seriam irrelevantes. Por outro lado, um cenário pessimista (mesmo que no curto prazo) traria implicações relevantes á sustentabilidade econômico-financeira do setor ( vide exemplo os momentos passados pós crise de 2008). Desta forma seriam válidos estudos complementares futuros considerando esta ótica.

\subsubsection{Cenário Realista}

Conforme avaliado no item referente aos condicionantes da demanda do etanol no Brasil, estes se decompõem na demanda do mercado interno e a demanda para exportação. A demanda para o mercado interno, por sua vez, se decompõe em demanda para de combustível para veículos ( flex-fuel) e demanda para outros usos (industriais, bebidas etc).

A demanda interna para uso combustível automotor, por sua vez, depende diretamente da frota de veículos e a configuração entre os usos de combustíveis (etanol, gasolina e gás natural), que por sua vez dependerá da relação de preços finais ao consumidor entre gasolina e etanol.

Estudos têm sido realizados com relação às projeções da frota de veículos nacionais. Conforme EPE(2008) com base em projeções da ANFAVEA, 2007, a frota nacional poderá alcançar em 2017 37,1 milhões de automóveis e os veículos flex-fuel representariam 73,6\% deste total, conforme mostra figura 32 . 


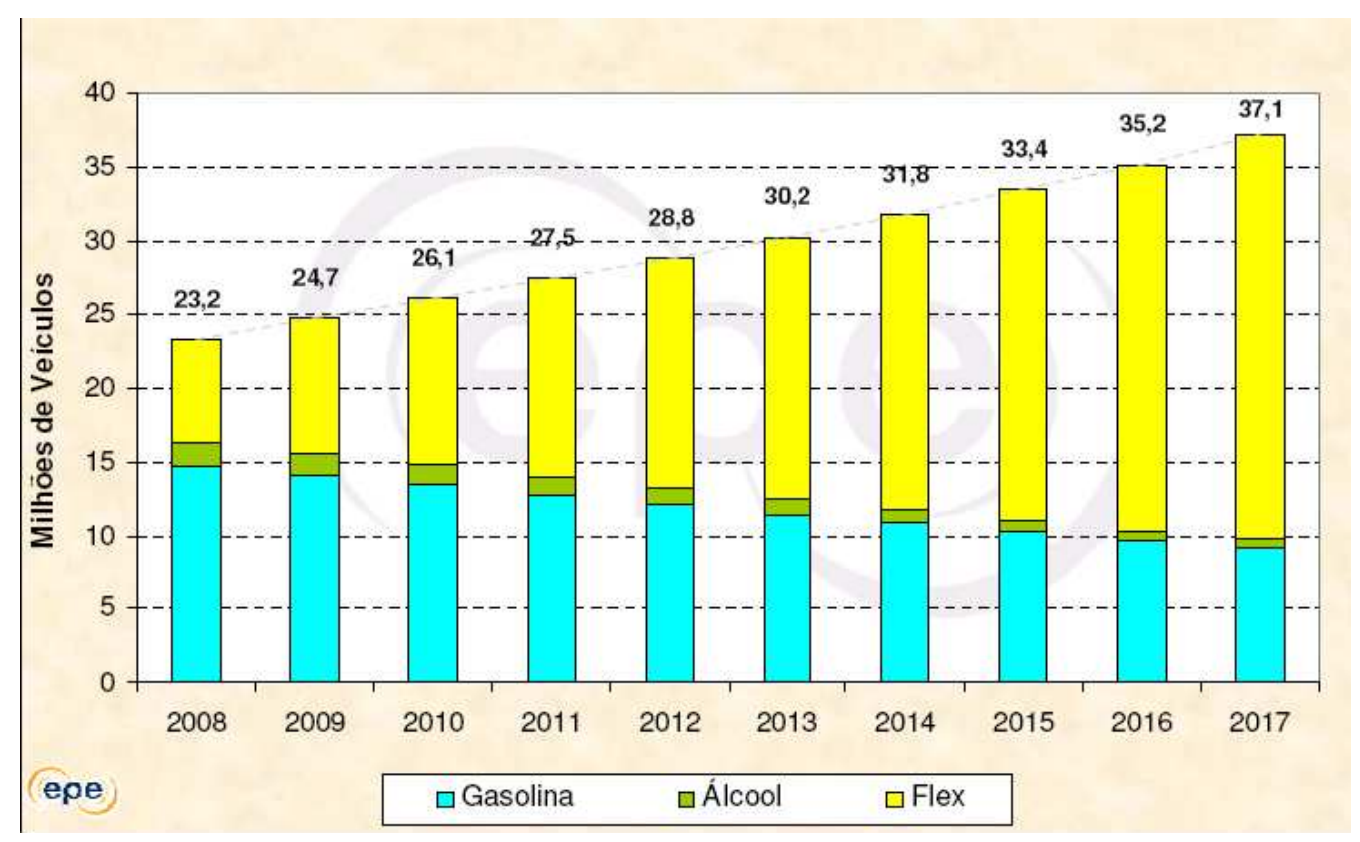

Figura 32 - Evolução da frota de veículos leves no Brasil por tipo de combustível Fonte : EPE, 2008

A partir desta perspectiva, a demanda estimada para consumo de combustível, conforme EPE, seria de 53,2 bilhões de litros em 2017 e 59,2bilhões em 2018 projetando linearmente a tendência de crescimento de $11,3 \%$ ao ano. A figura 33 ilustra este comportamento.

Projeção mercado in terno combustivel ( $b$ ilhõ es litros)

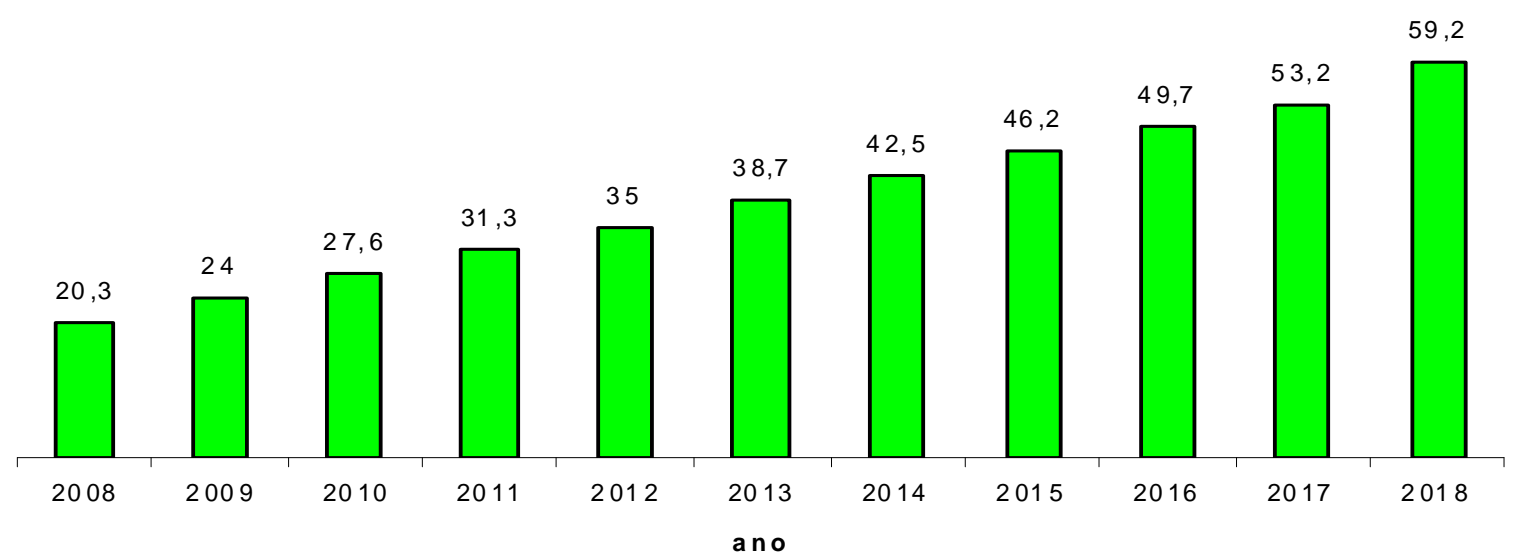

Figura 33 - Projeção de crescimento de demanda no mercado interno brasileiro de etanol para uso combustível Fonte : Autor com base EPE,2008 
Para outros usos no mercado interno brasileiro, conforme EPE (2008) a expectativa é a utilização de aproximadamente 650 Milhões de litros em 2010 chegando a 1,95 bilhões em 2017 e 2,3 bilhões em 2018. Os principais usos seriam bebidas, fármacos, cosméticos e termoplásticos. Diversas empresas investem em novos usos de "termoplásticos verdes" com base no etanol de cana-de-açúcar.

Quanto á demanda de etanol para exportação, conforme mencionado no item do presente trabalho referente aos principais mercados a serem atendidos são EUA, Europa, Japão e outros países selecionados. Conforme EPE (2008), a importação de etanol e mais especificamente do Brasil teve um pico no ano de 2008 devido à abrupta substituição do MTBE e as deficiências na logística interna no país. Porém a partir de então conforme EPE (2008) os novos investimentos na oferta contrabalancearão a demanda crescente, necessitando menos das importações conforme gráfico da figura 34.

proje çã o im portaçã o EUa ( bilh ões litros)

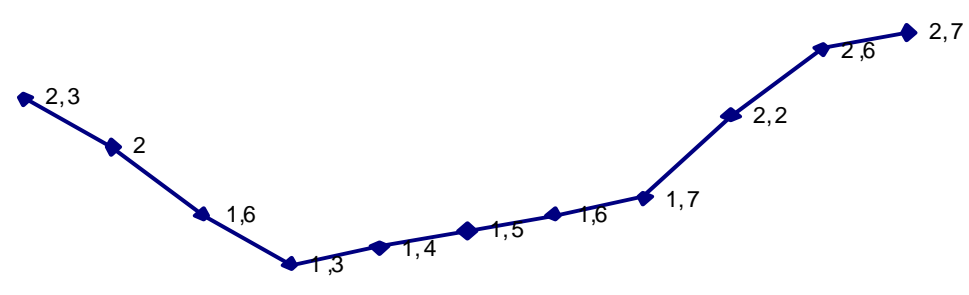

$\begin{array}{lllllllllll}2008 & 2009 & 2010 & 2011 & 2012 & 2013 & 2014 & 2015 & 2016 & 2017 & 2018\end{array}$

ano

Figura 34 - Projeção da importação de etanol por EUA - Cenário realista

Fonte: EPE, 2008 apud EIA,2008

Para o mercado europeu, foram consideradas algumas projeções moderadas conforme utilizadas por EPE (2008), conforme figura 35. 


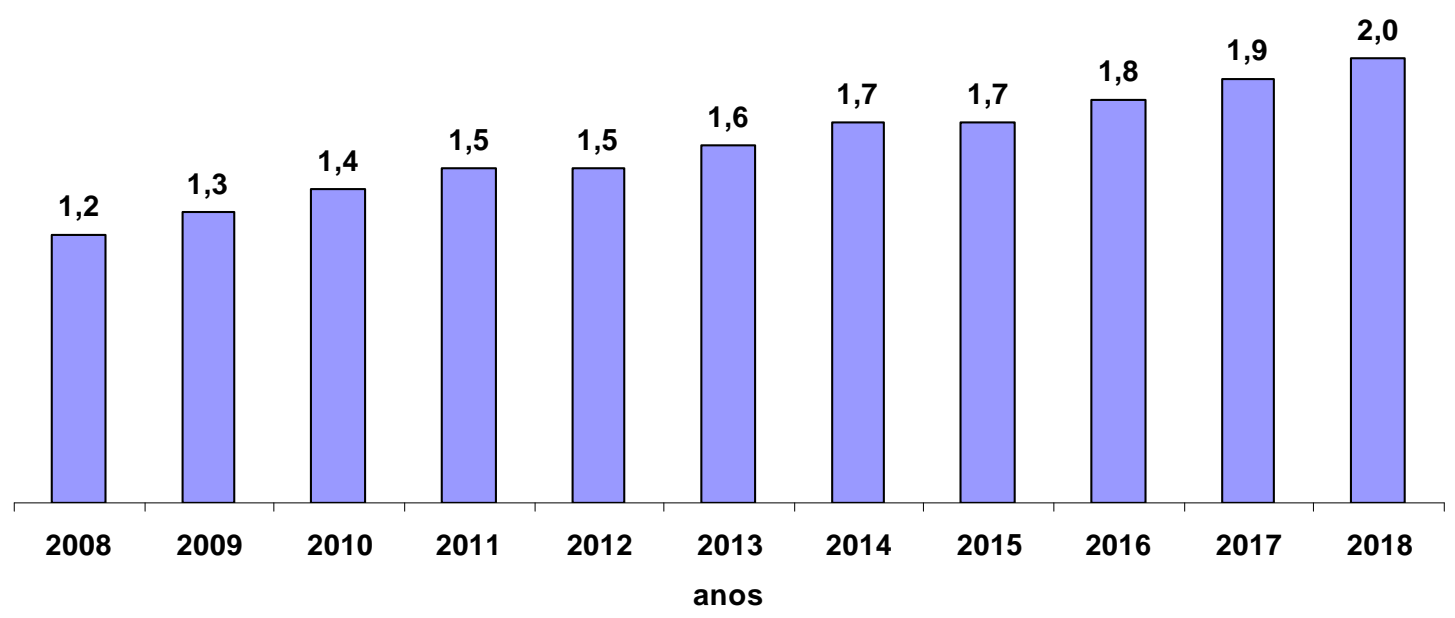

Figura 35 - Projeção da importação etanol EU - Cenário Realista

Fonte EPE, 2008 baseado em F.O.Licht,2008

No caso do Japão, o segundo maior importador de etanol do Brasil, foi considerada a expansão da importação dos volumes atuais ( 2007) de 364 milhões de litros para três bilhões de litros anuais em 2018 de forma linear, por conta do potencial conservador de 3\% (E3) de utilização de etanol em algumas cidades no país . A figura 36 mostra esta evolução.

\section{Japão - Bilhões de litros}

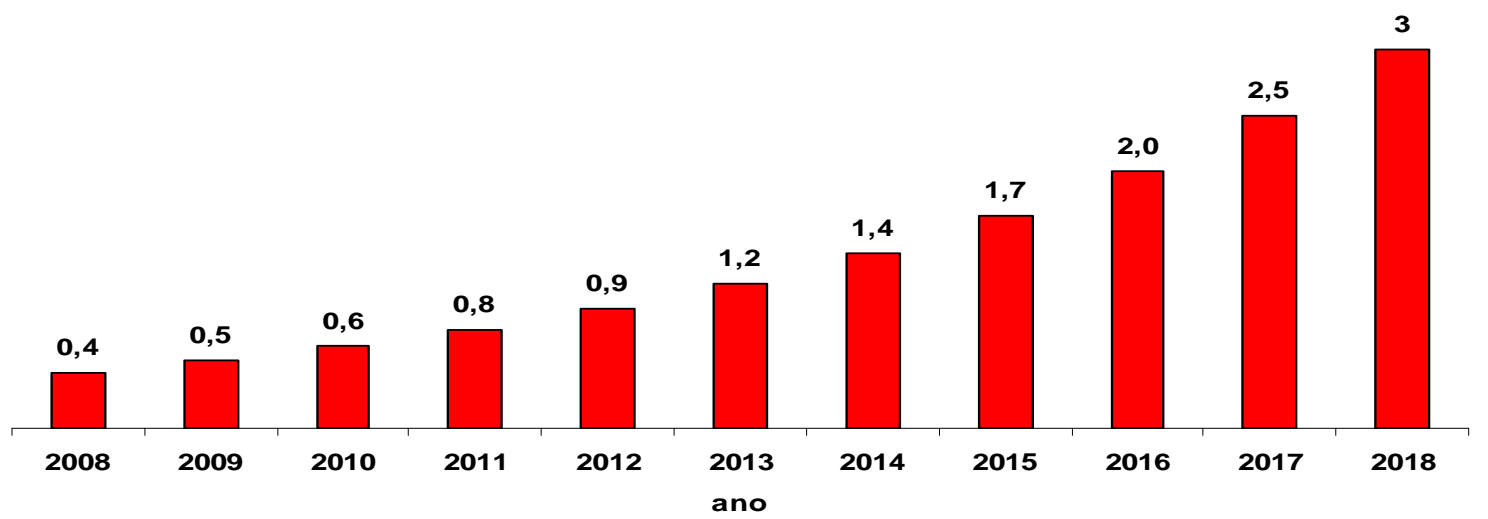

Figura 36- Projeção da importação de etanol brasileiro pelo Japão - Cenário Realista

Fonte: Autor

Para os demais mercados foram consideradas projeções, conforme EPE, fundamentadas principalmente na exportação para a China, de evolução de 550 milhões de 
litros em 2008 até 750 milhões em 2017. Na atual projeção foi considerada a evolução da demanda de forma linear conforme o gráfico da figura 37.

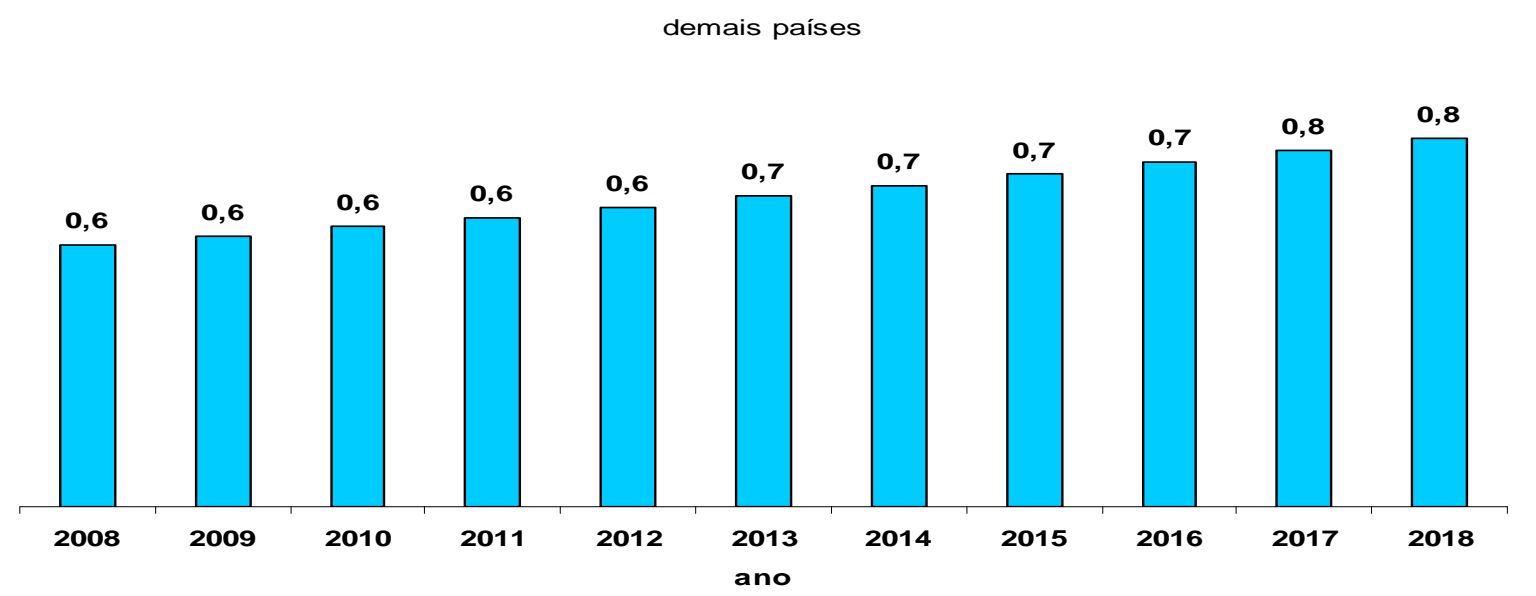

Figura 37- Projeção da importação de etanol brasileiro por demais países - Cenário Realista

Fonte: Autor

Como resultado, as projeções demonstram que o grande vetor de crescimento da demanda do etanol brasileiro é o mercado interno representando percentualmente $82 \% \mathrm{em}$ 2008 e $88 \%$ em 2018 do total respectivamente. Isto se deve ao fato que as premissas de crescimento consideram a perspectiva para o crescimento do mercado interno mais agressivo que no mercado exportador. A figura 38 ilustra esta questão:

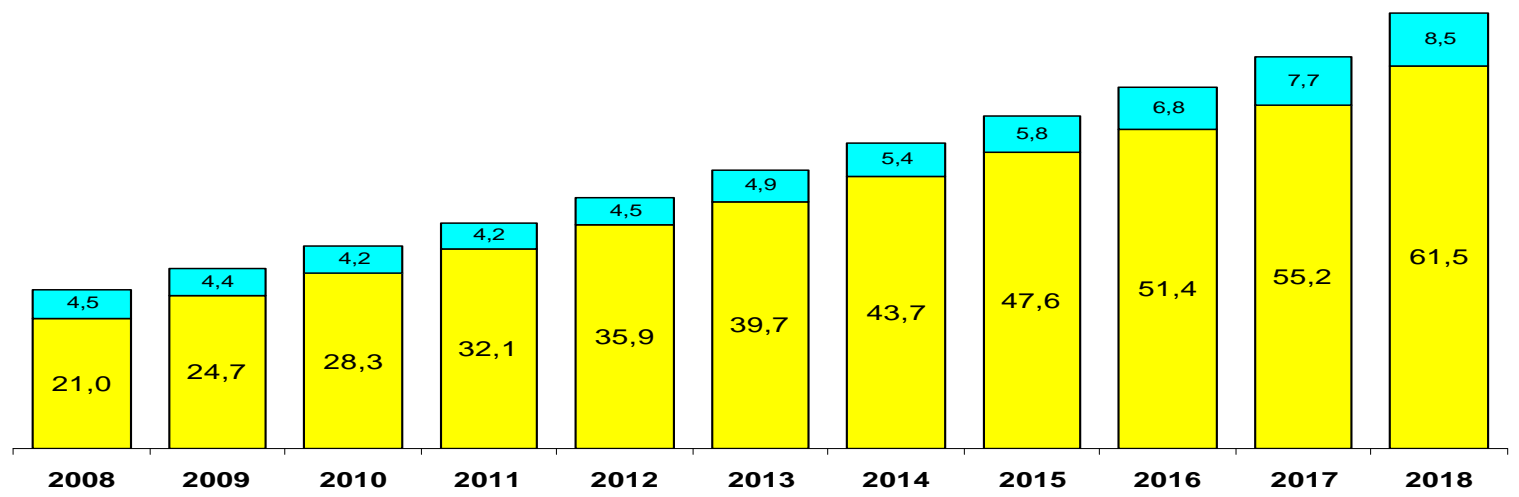

Figura 38 - Projeção da demanda total de etanol brasileiro - Cenário Realista ( bilhões de litros)

Fonte: Autor 


\subsubsection{Cenário otimista}

O cenário otimista contempla premissas mais agressivas de crescimento com base nos potencias que os condicionantes expostos anteriormente podem gerar. Assim a formulação deste cenário é de forma tentativa a partir da fragmentação dos componentes e condicionantes que compõem este modelo.

No caso da demanda interna para uso em combustíveis, a premissa básica do cenário realista é o crescimento orgânico da frota de veículos leves no Brasil, conforme a figura 29, a taxa de crescimento composto para a frota no período 2008 a 2017 seria de 5,35\% ao ano, considerando a entrada de novos veículos e a retirada de uso dos mais antigos. Também se considerou a manutenção das condições de preço etanol-gasolina, pré-requisito para a utilização do etanol nos veículos flex-fuel. Desta forma, a projeção final da demanda interna de etanol para uso combustível apresenta evolução de 11,3\% ao ano no período 2008 a 2017 e que foi extrapolada no presente trabalho até 2018.

Parece ser bastante pertinente em um cenário otimista, taxa de crescimento orgânico da frota maior que 5,35\% considerando a manutenção das condições macro-econômicas do país, concessão de crédito ao consumidor e a manutenção da relação favorável de preço etanol - gasolina.

Ao mesmo tempo, ao acelerar o crescimento da frota, acelerará mais ainda o consumo de etanol, na medida em que a substituição dos veículos antigos (e que usam gasolina unicamente) por veículos flex-fuel se dará mais rapidamente. Assim, tentativamente, é considerada neste cenário taxa de crescimento composta do crescimento da demanda interna de etanol para uso combustível em 15\% ao ano no período 2008 a 2018. A figura 39 mostra a evolução deste cenário. 


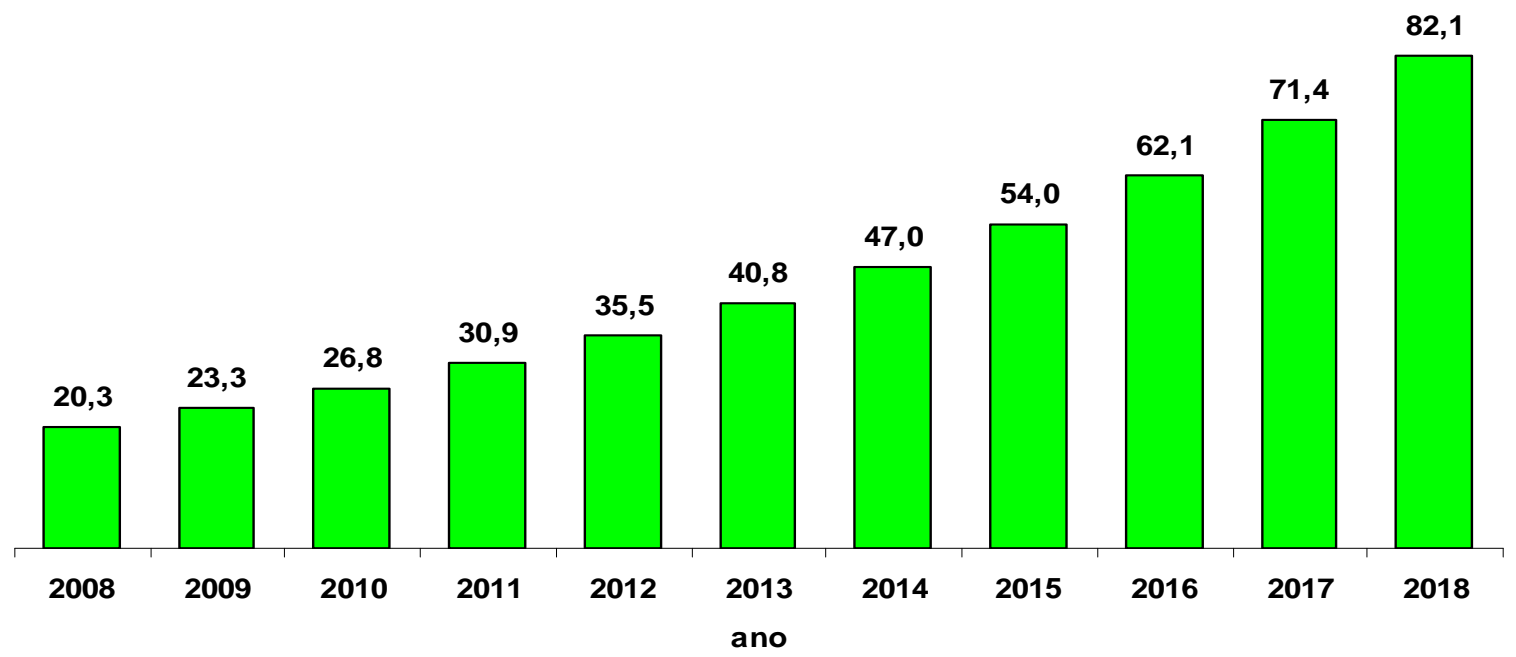

Figura 39 - Demanda interna etanol para uso combustível - Cenário otimista ( bilhões de litros)

Fonte: autor

Quanto à demanda interna de etanol por outros usos além do combustível, foi mantida a mesma condição apresentada no cenário realista, nesta condição a geração de demanda é mais lenta por conta dos investimentos em pesquisa e desenvolvimento particularmente necessários aos termoplásticos. Apesar de terem potencial de crescimento significativo. Outro componente importante, as bebidas, já é um mercado bastante maduro.

Quanto à demanda para exportação, começando pelos EUA, os dados utilizados para no cenário realista, se baseiam na premissa de significante crescimento da demanda norteamericana de etanol, mas que seriam supridas pelo incremento da capacidade produtiva nos EUA. Cabendo assim a importação nas lacunas de oferta e demanda do mercado interno norte-americano. No entanto, conforme mencionado no item 2.2.2, nos últimos tempos póscrise mundial de 2008, os governantes norte-americanos tem sofrido pressões de representantes da sociedade e setores, com respeito ao protecionismo econômico e fiscal dado ao etanol de milho.

Desta forma, é de se esperar no curto prazo a extinção ou pelo menos a redução da alíquota imposta ao etanol brasileiro de $\mathrm{R} \$ 0,54$ por galão de etanol. É importante relembrar que atualmente já existe um mecanismo para contornar a alíquota, a CBI-Caribean Basin Initiave, porém isenta em até o equivalente a $7 \%$ do volume produzido nos EUA no ano anterior. Assim amplia-se de forma significante o potencial à exportação do etanol brasileiro, por conta de sua competitividade de custos, ao mercado norte-americano. Para efeito do 
cenário é considerada taxa de crescimento de $25 \%$ ao ano sobre os valores projetados no cenário realista, a partir de 2011.

Para o mercado europeu, conforme citado no item 2.2.3, diversos mandatos ou sugestões têm sido discutidos no continente que podem acelerar de forma dramática a demanda por etanol ou biodiesel. Conforme EPE (2008), a comunidade européia sinalizou a participação de fontes renováveis em $10 \%$ na matriz energética na área de transportes, podendo assim representar algo como 30 bilhões de litros em 2016.

Para efeito do cenário otimista, é considerada a variação linear a partir de 2008 até 2017 com incremento de 50\% sobre os valores projetados no cenário conservador, totalizando 2,85 bilhões de litros em 2017 e 3,1 bilhões de litros em 2018. Figura 40 demonstra a evolução na Europa.

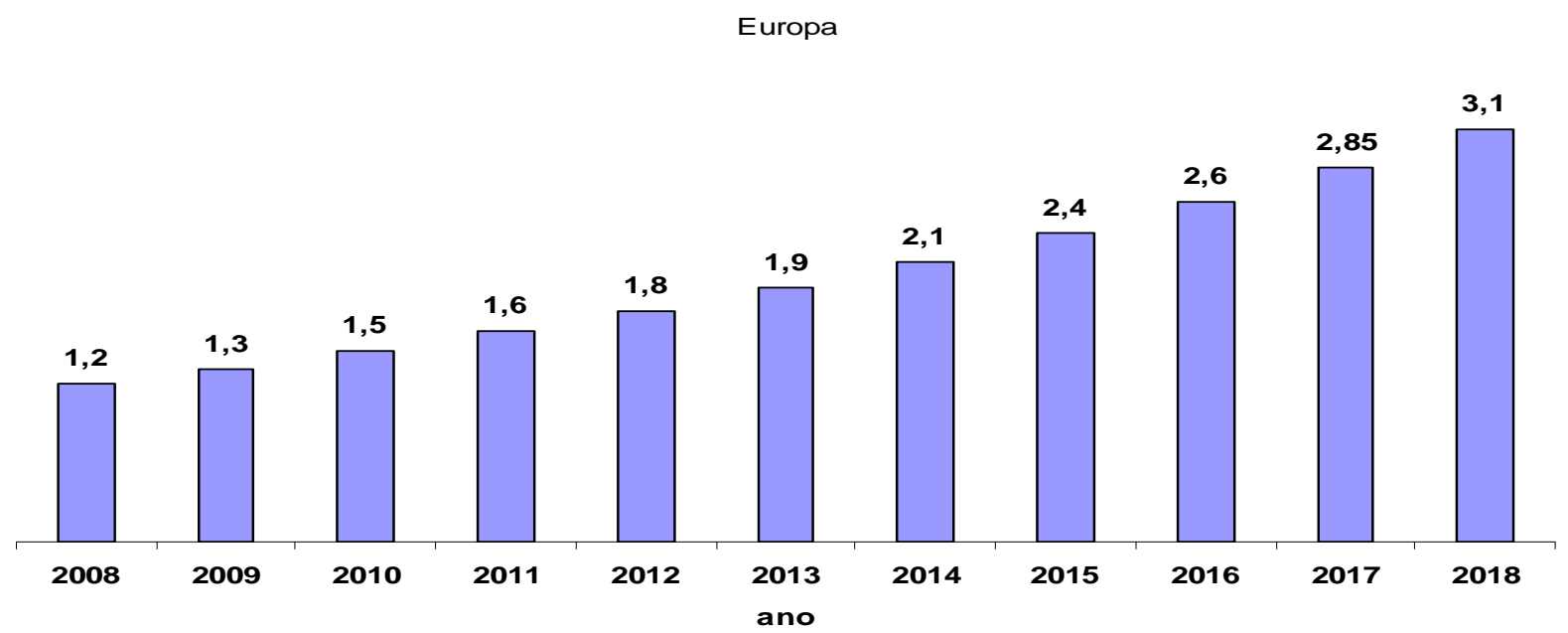

Figura 40 - Projeção exportação etanol para Europa - Cenário otimista ( Bilhões de litros

Fonte: autor

Com respeito às possíveis exportações ao Japão no futuro, este país representa a maior oportunidade individual para o crescimento das exportações. As premissas tomadas para o cenário realista consideram, conforme EPE (2008), acordos já realizados ou em desenvolvimento particularmente entre a Petrobrás e tradings companies japonesas podendo gerar potencial de exportação de 3 bilhões de litros em 2017. No entanto, o potencial de exportação é maior na medida em que estudos vêm sendo realizados pelo governo japonês, conforme ainda EPE (2008), para incrementar a participação do etanol dos atuais 3\% ( não obrigatórios) para até $10 \%$ em 2012. Como o país, essencialmente não produz etanol, uma pequena parcela de etanol apenas é produzida a partir do etileno, e estudos e acordos vêm 
sendo desenvolvidos entre o Japão e Brasil, é de se esperar que o Brasil seja um grande fornecedor de etanol ao Japão nos próximos anos.

Para efeito do cenário otimista, foi considerado o incremento linear de 50\% na demanda sobre os valores do cenário realista. A figura 41 ilustra esta evolução.

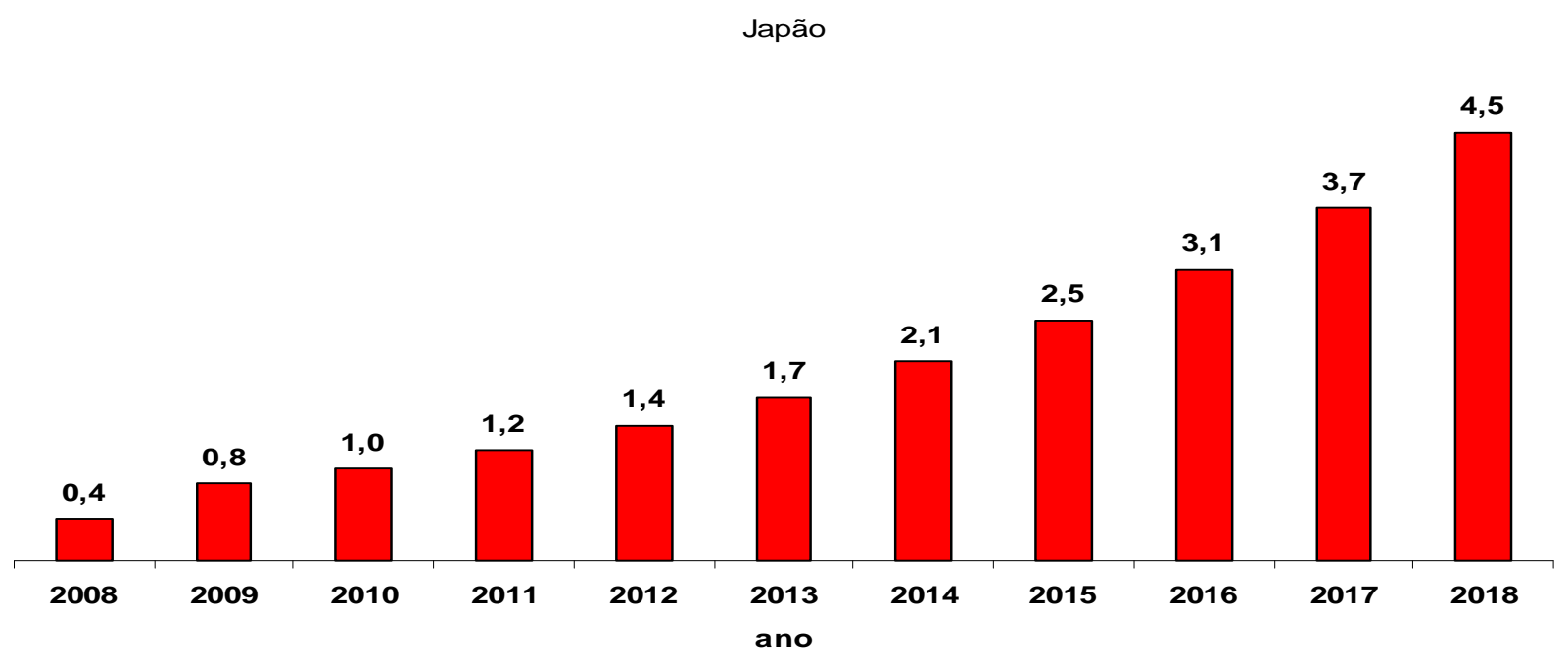

Figura 41 - Projeção de exportações de etanol brasileiro para o Japão - cenário otimista (bilhões de litros) Fonte : autor

Os demais países, capitaneados pela China, também possuem potencial significativo de crescimento. Particularmente no caso chinês por conta das iniciativas em andamento com respeito ao uso de combustíveis renováveis e pela demanda reprimida de veículos automotores, possui grande potencial de crescimento nos próximos anos. Para efeito do cenário otimista foi considerada taxa de crescimento de $100 \%$ ao ano sobre os valores projetados no cenário realista a partir de 2011.

O figura 42 apresenta a evolução total da demanda de etanol brasileiro no cenário otimista, segmentado por mercado interno e mercado de exportação . 


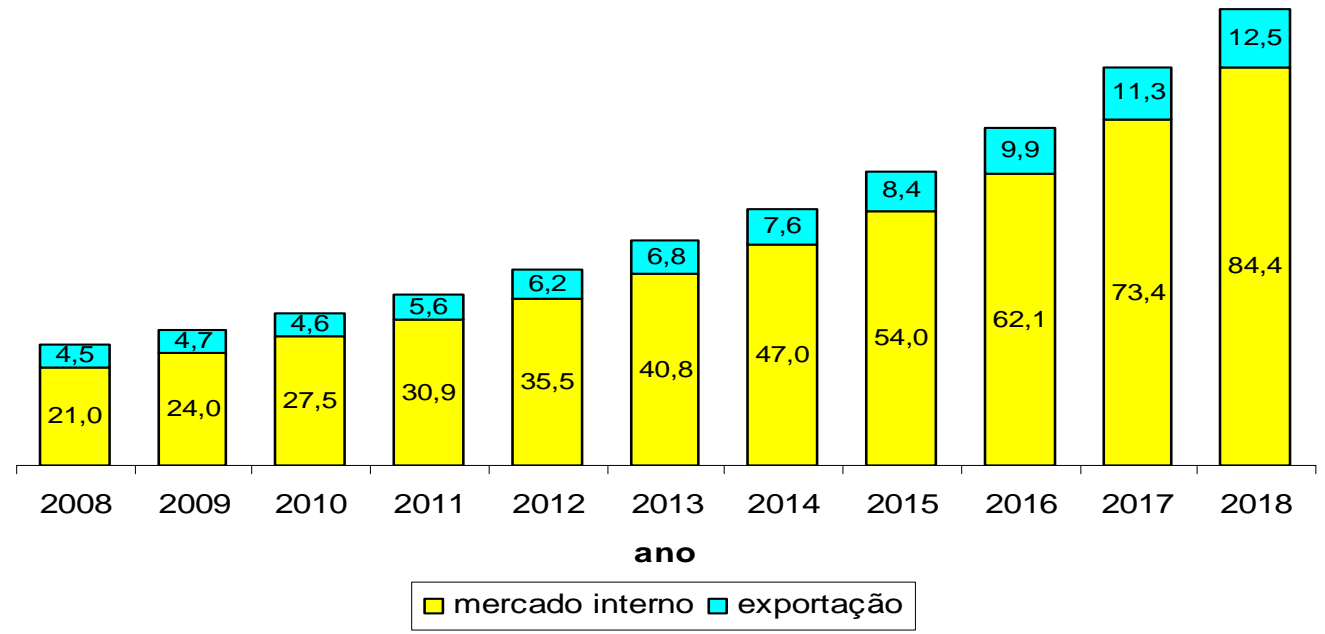

Figura 42 - Projeção de demanda total de etanol brasileiro - cenário otimista ( bilhões de litros )

Fonte: Autor

\subsubsection{Análise de resultados}

O cenário realista apresenta configuração baseada no cenário projetado pela EPE (2008), ajustado metodologicamente em alguns casos. Portanto a evolução é bastante similar conforme mostra na figura 43. Da mesma maneira outros estudos: UNICA (2007) e MAPA (2007), cenários foram projetados e tiveram comportamento similar, conforme mencionado no trabalho realizado em EPE (2008). Tanto o cenário realista e também o estudo EPE, 2008 apresentaram resultados superiores aos da UNICA e MAPA, por conta de considerar também a evolução da demanda interna de usos não combustíveis.

De qualquer forma, os resultados variaram, em 2017, de 54,3 bilhões de litros de demanda de UNICA (2007) a 63,9 bilhões de litros conforme EPE (2008) representando uma variação de $18 \%$ sobre o menor valor. Portanto pode-se concluir que os cenários projetados (incluindo o cenário realista do presente trabalho ) foram bastante similares para o período estudado.

No caso do cenário realista a evolução projetada foi de $10,6 \%$ ao ano no período 2008 a 2018 sendo inferior à taxa real de crescimento do período 2004 a 2008 que foi de aproximadamente $16 \%$ ao ano conforme MAPA (2009). Isso se deve ao fato de que durante 
este período, o crescimento da frota de veículos flex-fuel no Brasil foi significante .As vendas de veículos flex-fuel em 2004 representaram 22\% do total em 2004 e 91,3\% em 2007.

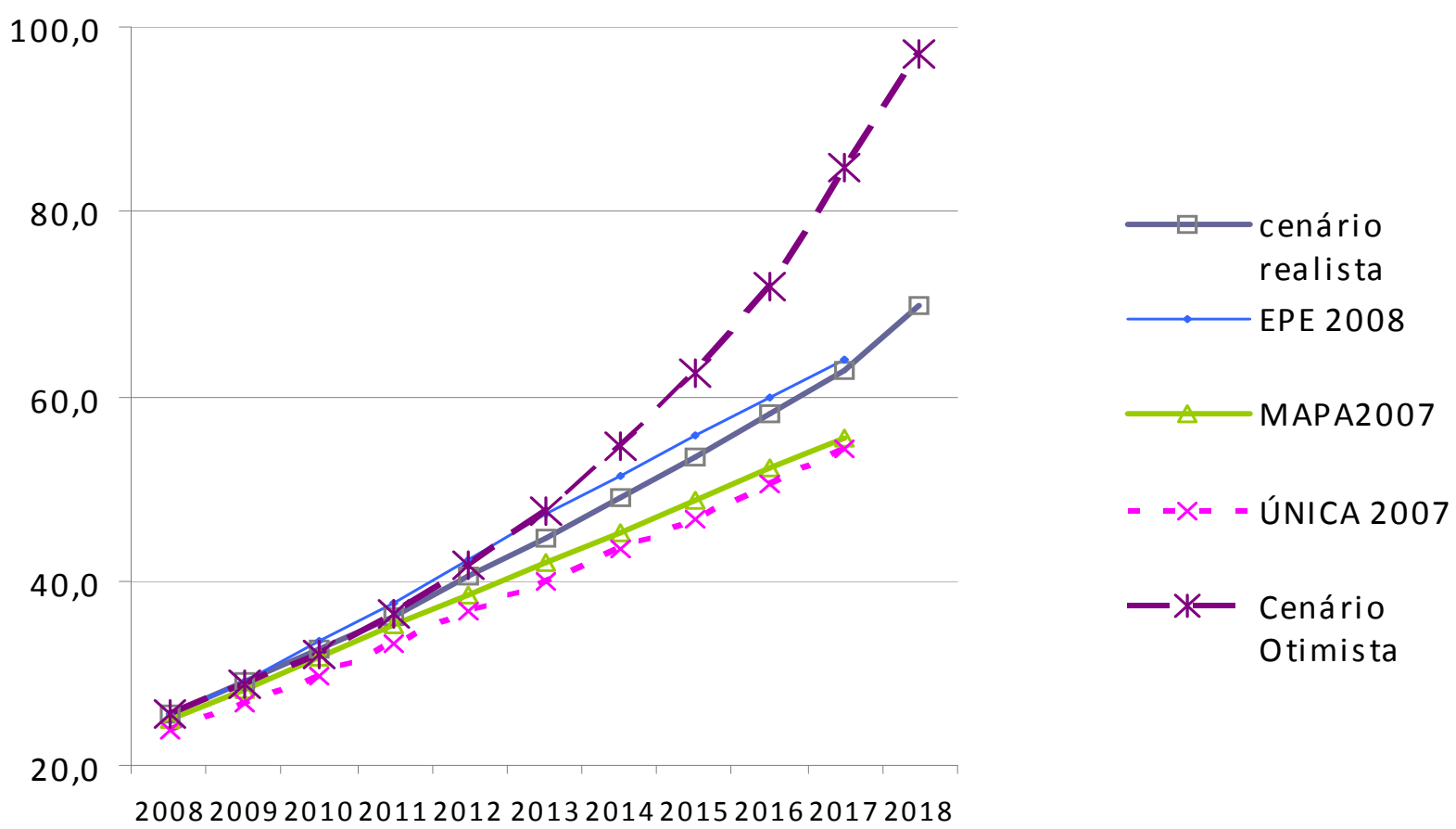

Figura 43 - Comparativo de projeções de demanda do etanol nos cenários realista, otimista e outros estudos similares ( Bilhões de litros )

Fonte: autor

Ainda assim, no cenário realista, a evolução da demanda para o mercado interno foi maior do que no mercado de exportação, dadas as condições ainda pouco claras dos países passíveis de importarem em maior escala do Brasil. Neste cenário, as taxas de crescimento anual da demanda interna e da demanda para exportação entre 2008 e 2018 foram de, respectivamente, $11,3 \%$ ao ano e 6,6 \% ao ano. Em 2008, o etanol a ser exportado representaria 18\% da produção total e em 2018 apenas $12 \%$.

O cenário otimista, por sua vez, apresenta taxa de crescimento composto de $14,4 \%$ ao ano no período 2008 a 2018. Sendo que apresenta diferentes perfis de crescimento ao longo do período analisado. Entre 2008 a 2013 e 2013 a 2018 o crescimento seria de 13,3\% ao ano e $15,3 \%$ ao ano, respectivamente. Isto se deve, principalmente, às premissas de aceleração das exportações para os principais países. As taxas de crescimento para o mercado interno e exportação no período 2008 a 2018 são de 14,9\% ao ano e 10,8\% respectivamente. Porém nos períodos entre 2008 e 2013 e entre 2013 e 2018 tiveram crescimento diferenciados. No 
caso do mercado interno, as taxas de crescimento de $14,2 \%$ e $15 \%$ respectivamente. No caso do mercado para exportação $9 \%$ e $13 \%$ respectivamente.

Sob a ótica do atendimento à demanda do etanol, ou seja, pelo lado da oferta, estudos foram realizados baseados nos cenários apresentados de forma comparativa (EPE, UNICA e MAPA), fazendo-se valer dos projetos atuais e futuros de atendimento à demanda nos próximos anos. Como o cenário foi tomado como referência para o estudo presente no cenário realista e, ao mesmo tempo, as demandas projetadas são superiores aos demais estudos mencionados ( UNICA e MAPA), as avaliações são pertinentes ao cenário realista realizado.

Conforme EPE (2008), para uma visão de curto prazo, a partir de 2008 a 2010, 72 novas usinas estavam sendo implantadas e outras 23 estavam em estudo. Estas usinas em operações poderiam atender a uma demanda estimada de 33,5 bilhões de litros anuais, ou seja, dentro das previsões do cenário de crescimento previsto por EPE (2008) neste período. Além desta visão de curto-prazo, conforme mostra EPE (2008), é difícil estimar a oferta com bases concretas, na medida em que os investimentos em usinas podem ser concretizados em 3 ou 4 anos.

Estudo realizado por MAPA, 2007 referente à oferta, requereria a instalação de 25 novas usinas anualmente a partir de 2008 até 2017 para o atendimento à demanda projetada de 55 bilhões de litros em 2017.

Conforme a tabela 14 os incrementos necessários na produção para o abastecimento da demanda prevista em EPE (2008) podem seguir incremento anual de aproximadamente quatro bilhões de litros. Por efeito dos ganhos de produtividade e desenvolvimento tecnológico a expectativa é que as novas unidades fabris ( usinas ) aumentem sua produção passando dos atuais 200 milhões de litros-ano para 400 milhões de litros-ano por usina em 2015 em diante.As novas usinas obviamente já incorporarão todos os avanços tecnológicos e possíveis ganhos de escala trabalhando em nível ótimo de produção.

Estima-se, conforme fontes do setor, que o tamanho ótimo de uma usina de cana-deaçúcar é moer entre 3,5 a 4 milhões de toneladas-ano de cana. Menos que isso, perde-se em ganhos de escala e mais que estes valores perde-se em custos de transporte para trazer a cana à usina e perde-se na degradação do açúcar, na medida em que quanto maior a capacidade da usina, maior a distância para se trazer a cana-de-açúcar do campo. Portanto, tanto os ganhos de produtividade que acompanham o setor quanto à possibilidade de realizar investimentos "modulares" oferecem aos usineiros e investidores a opção de investir á medida que as 
percepções de demanda se tornarem mais atraentes. Desta forma podem garantir o suprimento da demanda, enquanto produção, minimizando riscos no investimento.

Tabela 14 - Estimativa de aumento de oferta nos próximos anos no Brasil

\begin{tabular}{|c|c|c|}
\hline Ano & $\begin{array}{c}\text { Incremento de Etanol } \\
\text { (bilhōes de litros) }\end{array}$ & $\begin{array}{c}\mathbf{N}^{\circ} \text { usinas } \\
\text { necessárias }\end{array}$ \\
\hline $\mathbf{2 0 1 1}$ & 4,16 & 21 \\
\hline $\mathbf{2 0 1 2}$ & 4,65 & 23 \\
\hline $\mathbf{2 0 1 3}$ & 4,98 & 17 \\
\hline $\mathbf{2 0 1 4}$ & 4,27 & 14 \\
\hline $\mathbf{2 0 1 5}$ & 4,18 & 12 \\
\hline $\mathbf{2 0 1 6}$ & 4,06 & 12 \\
\hline $\mathbf{2 0 1 7}$ & 4,14 & 10 \\
\hline
\end{tabular}

Fonte: EPE, 2008

No cenário otimista, que conforme figura 39, poderá gerar demanda de aproximadamente 97 bilhões de litros de etanol em 2018, ou seja, incremento de 27,1 bilhões de litros em 2018 ou 39\% em comparação ao mesmo ano no cenário realista. Como a diferença basicamente entre os dois cenários se dá a partir de 2013 em diante, pode-se admitir que para alcançar a demanda projetada no cenário otimista, será necessário o suprimento de adicionais 5,4 bilhões de litros por ano até 2018. Considerando ainda o valor médio de capacidade produtiva de usina de 350 milhões de litros-ano , conforme EPE (2008), seriam necessárias adicionais 15 novas usinas ao ano. Pelo lado da necessidade de área a ser plantada e considerando dados estatísticos conservadores, seriam necessários adicionais 3,9 milhões de hectares para suprir os adicionais 27,1 bilhões de litros- ano em 2018 para o cenário otimista. É um valor expressivo, porém plenamente factível dentro da extensão territorial e do potencial de expansão da cultura em nosso país.

A questão é que a expansão do plantio se dá e deverá se acentuar em regiões cada vez mais distantes dos grandes centros e da costa brasileira, notadamente centro-oeste e norte paranaense conforme discutido no presente trabalho. E este fato ressaltará ainda mais a importância dos aspectos logísticos. 


\subsubsection{Impactos e necessidades na logística de distribuição}

Os impactos e necessidades da logística de distribuição a partir dos cenários gerados ocorrem nas várias fases do processo logístico conforme apresentado no item 2.3.

No fluxo primário ou coleta, que leva o etanol das usinas aos centros primários ou secundários de distribuição, essencialmente realizado no caso do etanol por modal rodoviário ( assim como na entrega), por conta da capilaridade e fragmentação da localização das usinas ( e dos pontos de venda, no caso da entrega).

Uma estratégia significante é a aproximação das bases primárias dos centros produtores para a aglutinação de volumes mais próximos da produção e conseqüentemente a redução de custos logísticos porque, entre outros fatores, o custo logístico da coleta é alto. Esta estratégia faz muito sentido para a expansão de oferta para fronteiras distantes do centrooeste. Mesmo assim, será necessário incremento substancial da frota de caminhões para a coleta de etanol e entrega nos pontos de comercialização.

Sob a ótica do atendimento à demanda não representa um gargalo em si, na medida em que a produção e entrega de caminhões poderá ocorrer ajustando a demanda por caminhões e a oferta por parte das montadoras de veículos. Uma contrapartida deste modal é relativa ao impacto no custo total do etanol, haja vista que o custo por quilômetro deslocado neste modal é o mais alto de todos. Além disso, a condição precária das estradas brasileiras encarece os custos de logística ( manutenção, gastos excessivos com combustível etc) conforme Figueiredo (2005), pode aumentar o custo de transporte em 5\%.

A logística envolvida na transferência (entre bases primárias e secundárias ) e de entrega, no caso para exportação, envolve diferentes modais com custos totais menores mas que requerem escala de transporte por conta dos investimentos maiores.

O modal ferroviário já tem sido extensivamente utilizado no transporte de combustíveis, notadamente de derivados de petróleo, e representam $61 \%$ do transporte entre bases, conforme Figueiredo (2005) em estudo realizado por Coppead/ IBP existe a necessidade de se investir atualmente 700 milhões de reais para minimização dos gargalos atualmente existentes, sendo que especificamente para o transporte de combustíveis seriam necessários 90 milhões de reais para melhorias de infra estrutura e desenvolvimento de novos vagões -tanque para transporte de combustíveis.

Quanto ao modal hidroviário, conforme Xavier ( 2007 ), a hidrovia Tietê -Paraná deverá em 2014 propiciar do transporte de 3,5 bilhões de litros anualmente. Um gargalo recorrente à utilização de diferentes modais são os pontos e infra-estrutura de transbordo. Este 
é um fator crítico, ao final das contas, aumenta ou agiliza tempos de transbordo e custos operacionais e totais.

Quanto ao modal dutoviário, conforme discutido no item sobre modal dutoviário do presente trabalho, diversos projetos vem sendo realizados na construção de dutovias para o transporte de etanol principalmente com vistas à exportação e ao aumento da demanda.

$\mathrm{O}$ atual sistema integrado multimodal, segundo EPE, comporta atualmente o transporte de 3,6 bilhões de litros de etanol por ano envolvendo dutovia e ferrovias. Deste total, 2 bilhões se referem à capacidade da Transpetro ( subsidiária da Petrobrás ) e 1,6 bilhões de empresas privadas.

Os novos projetos de expansão dutoviária, poderão aumentar a capacidade de transporte em 12 bilhões de litros-anos nas regiões Centro-oeste/ sudeste, cinco bilhões de litros-ano na região sul e mais 0,75 bilhões de litros para a região nordeste conforme EPE (2008).

Além destes projetos dutoviários, conforme também discutido no item 2.3.2, outros projetos privados vem sendo desenvolvidos como da Brenco com capacidade de transporte prevista de quatro bilhões de litros -ano para exportação e mais dois bilhões de litros-ano para transferência no mercado interno. Além deste ainda existe o consórcio Uniduto, composto por grandes produtores independentes cuja produção somada atualmente resultam em nove bilhões de litros ano. Não foi obtido acesso à capacidade de transporte desta dutovia.

Portanto, ao comparar com os cenários gerados, mesmo no caso otimista, o atendimento à demanda, particularmente à exportação, pelos meios dutoviários, poderá ocorrer. Novos projetos no curto prazo provavelmente não se viabilizarão, mesmo com a demanda crescente, na medida em que a necessidade de escala no meio dutoviário é alta.

Conforme alega Figueiredo (2005) no estudo realizado por Coppead/IBP mostrou que novos projetos dutoviários não seriam viáveis para transporte de combustíveis dentro de rotas selecionadas por conta do não atendimento à escala necessária. A figura 44 ilustra a questão abordada. 


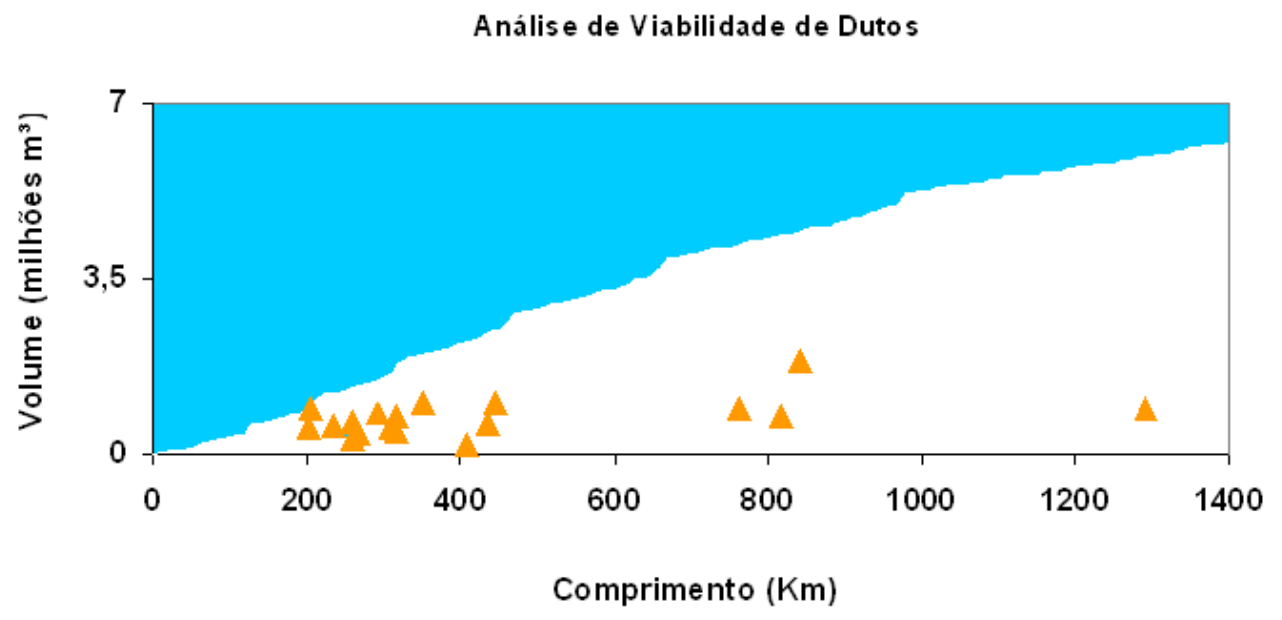

Figura 44 - Escala de viabilidade econômica de dutovias em função da distância e volume Fonte: Figueiredo, 2005

No entanto, similarmente à construção de novas usinas, o aumento da malha dutoviária também é factível na medida em que a aceleração da demanda criar um cenário mais favorável á expansão. Isto dito, pois para a viabilização de um novo projeto dutoviário, são necessários 4 a 5 anos, sem contar com as licenças ambientais, conforme fontes do setor.

Estes corredores de exportação dutoviários contemplam também em seus projetos a expansão de terminais nos portos marítimos.

Em resumo, a expansão da oferta do etanol fruto da demanda crescente pelo combustível, poderá, em tese, ser atendida pela logística como está configurada atualmente e pelos projetos de expansão em vigor. No entanto, alguns gargalos que comprometem produtividade e conseqüentemente custos são observados. A utilização em larga escala do modal rodoviário, em condições no qual ele é mais apropriado (coleta e entrega) ou como "tapa-buracos" nos pontos de transferência não cobertos por outros modais, faz com que o custo total, e conseqüentemente a competitividade do setor, aumente dramaticamente. Outro aspecto relevante no tocante à logística é a possibilidade de expansão da malha logística à medida que as perspectivas de crescimento de demanda se tornarem mais claras. Neste sentido, os agentes privados (empresas, investidores) podem realizar investimento com menores riscos associados e garantir o abastecimento de etanol. Por último e ligado ao aspecto anterior, o papel e a atuação pública é fundamental como fomentador no longo-prazo do desenvolvimento do setor. Isto vale em diversos aspectos levantados no presente trabalho, 
mas especificamente fica claro o papel da Transpetro no desenvolvimento de corredores para exportação com vistas ao longo prazo, mesmo com as incertezas do presente. Conforme discutimos no item 2.4.1, o posicionamento e atuação governamental brasileira é um condicionante básico para a expansão do etanol brasileiro no mundo. 


\section{CONCLUSÕES}

A questão do etanol brasileiro como fonte renovável e limpa tem tido relevante significado e importância nos últimos anos, seja nas discussões internas ao Brasil seja nos ambientes internacionais como fonte global de combustíveis. O presente trabalho procurou elucidar as nuanças do etanol brasileiro: o histórico, os principais envolvidos, questões tecnológicas, as tendências, condicionantes para o crescimento, projeções de demanda futura e implicações na logística de distribuição.

No tocante ao histórico do etanol no Brasil, se confunde com a formação econômica e social de nosso país particularmente na região nordeste a partir do século XVII, envolvendo inclusive a formação da cultura e do povo brasileiro. O autor deste trabalho teve a oportunidade de realizar uma avaliação administrativa em antiga usina de cana-de-açúcar no norte fluminense, originalmente do século XIX, que ainda hoje, muitos dos trabalhadores da usina são descendentes de ex-escravos que trabalharam nesta usina. O desenvolvimento da Cana-de-açúcar tem se dado mais recentemente na região sudeste e centro-oeste, particularmente nos últimos 30 anos no século $\mathrm{XX}$.

O Brasil se tornou nos últimos anos o maior produtor mundial de cana-de-açúcar e o segundo maior produtor mundial de etanol, sendo responsável pela maior parte do comércio internacional de etanol, na medida em que o maior produtor mundial (EUA) essencialmente produz para abastecer o mercado interno. As características bioquímicas da cana-de-açúcar e também as condições geográficas do Brasil, fazem com que o etanol à base de cana-de-açúcar seja atualmente o combustível líquido renovável e limpo mais produtivo e com o menor custo de produção existente mundialmente.

O sucesso do etanol brasileiro foi devido inicialmente ao Proálcool, programa que incentivou o uso do etanol á base de cana-de-açúcar como combustível de automóveis, a partir das crises mundiais do petróleo dos anos 70 e aos bem sucedidos projetos de desenvolvimento da cana-de-açúcar realizados pela EMBRAPA .

Por este mesmo fator faz com que outros países produtores de etanol a partir de outras culturas adotem medidas protecionistas frente à importação do combustível brasileiro.

Atualmente o setor sucroalcooleiro no Brasil é dominado essencialmente por empresas privadas, cada vez mais profissionais e mais recentemente internacionais, que tem modernizado o setor em busca de retornos atrativos e de longo prazo. A atuação governamental, no entanto, e diga-se essencialmente da Petrobrás, tem-se mostrado forte definindo posicionamentos e investimentos de longo prazo para a construção internacional do 
setor. Isto a despeito das preocupações dos demais Players do mercado, receosos com a atuação e o domínio excessivos da estatal.

Conforme discutimos no tocante aos direcionadores para o crescimento da demanda do etanol, tudo começa em três grandes fatores: a percepção global da necessidade de utilização de fontes renováveis e limpas de energia, o esgotamento e o encarecimento das fontes não renováveis de energia, notadamente o petróleo, e a macro-economia global que direciona a necessidade de mais ou menos energia para sustentar o crescimento econômico.

A partir daí, outras condicionantes definem a demanda por etanol. Notadamente neste nível, o posicionamento governamental (no caso do Brasil e dos países potenciais importadores do etanol brasileiro) perante a questão de utilização de fontes renováveis de energia. No caso do governo brasileiro intervindo em duas grandes frentes: facilitando a construção e desenvolvimento da indústria do etanol no Brasil, desde a facilitação de pesquisa científica em variedades genéticas de cana, passando por meios de produção e até criando condições e mecanismos de governança e controle que auxiliem o setor privado na produção e comercialização do etanol dentro e fora do país. Foi discutido no presente trabalho as nuances cíclicas e sazonais da cultura do etanol, que envolve tanto o regime de chuvas anual e os ciclos de médio-longo prazos de investimento e retorno no negócio.

Outra frente clara desenvolvida pelo governo brasileiro para fomentar $o$ desenvolvimento do etanol se refere às ações de cunho internacional para a formalização e padronização do etanol como commodity internacional. Atualmente o etanol, diferentemente da gasolina, é comercializado de forma spot, no mercado á vista essencialmente. Portanto ações do governo brasileiro e entidades ligadas ao setor ( por exemplo UNICA) desenvolvem significante trabalho neste sentido, em rodadas de negociação, câmaras de comércio, pleitos comerciais, entre outros.

Pelo lado dos países importadores, a grande questão é relativa às barreiras econômicas à importação do etanol brasileiro. No entanto, com a crise mundial de 2008 principalmente, os subsídios oferecidos aos setores alcooleiros destes países vem sendo questionados internamente pelos próprios meios internos a estes países. Desta forma, mudanças significativas nestes quadros protecionistas podem gerar uma aceleração à demanda de etanol importado, no qual o brasileiro se destaca.

Para a demanda de etanol no mercado interno brasileiro, o principal condicionante é o crescimento da frota de veículos automotores flex-fuel e a manutenção da relação de preços na ponta do consumo entre etanol e gasolina. Este último, novamente tem sido muito uma questão do posicionamento governamental brasileiro incentivando o uso do etanol em 
detrimento da gasolina como combustível automotor no mercado interno. O excedente produzido de petróleo e a sua conversão para a gasolina no país têm claro viés político para exportação.

Foram desenvolvidos dois grandes cenários de expansão da demanda do etanol brasileiro: cenário realista, baseado em perspectivas aceitas e também desenvolvidas por entidades ligadas ao setor ( EPE, MAPA, UNICA) . Foi tomado como base essencialmente o cenário desenvolvido por EPE em 2008 e nos principais direcionadores trabalhados anteriormente. $\mathrm{O}$ cenário otimista em que se procurou agregar marginalmente ao cenário realista perspectivas de crescimento mais agressivas. Estas perspectivas foram utilizadas particularmente na abertura e crescimento de mercados internacionais e também na taxa de crescimento da frota de veículos flex-fuel no Brasil. Como resultado atingiram as demandas previstas de etanol em 2018 tanto no cenário realista quanto otimista de 69 bilhões de litrosano e 97 bilhões de litros-ano, respectivamente.

Para o cenário realista, a demanda projetada poderá ser atendida na medida em que vários estudos privados ou não foram realizados e as projeções de oferta vislumbram a necessidade de usinas adicionais com taxa crescente de construção e operação que vão de 10 EPE (2008) a 25 MAPA(2007). Pelo lado da logística de distribuição, no entanto, aumenta a complexidade, na medida em que os centros de produção estarão cada vez mais distantes dos grandes centros de consumo e exportação.

Com relação ao cenário otimista ocorreria um incremento da ordem de 27 bilhões de litros em 2018 em comparação ao cenário realista, que por sua vez poderia ser representado como um incremento de 4 a 5 bilhões de litros anuais com relação ao cenário realista. Neste cenário, iria requerer adicionalmente ao cenário realista, a construção de 15 novas usinas por ano. Pelo lado da logística, poder-se-ia viabilizar novos dutos na medida em que geraria volume suficiente a ser transportado e distâncias longas a serem vencidas ( a questão do aumento da distância da produção ao consumo/exportação se intensificaria ). Conforme estudos consultados, a escala necessária para viabilização dos alcooldutos seriam por volta de cinco bilhões de litros - ano.

O corredor hidroviário, por sua vez, tem papel restrito, na medida em que só é possível utilizar hidrovias nos locais onde existem rios caudalosos e propícios à navegação. De qualquer forma, o potencial de transporte de 3,5 bilhões de litros anuais na rota Tietê-Paraná irá auxiliar a distribuição particularmente entre bases.

Por outro lado, tanto no cenário realista quanto no cenário otimista, se intensificaria o uso do modal rodoviário, tanto por conta da necessidade de coleta e entrega, como para suprir 
as lacunas nos transbordos e problemas em rotas pouco atendidas nas transferências. Porém este é o modal mais caro considerando-se distância percorrida e nas condições das rodovias e estradas vicinais no país, representam um incremento significante de custos e perda de competitividade.

O uso do modal ferroviário é uma alternativa interessante e poderá suprir muito da necessidade de transporte de etanol particularmente nas transferências entre bases. 


\section{CONSIDERAÇÕES FINAIS}

O presente trabalho procurou mostrar aspectos sistêmicos relacionados á questão do etanol no Brasil e as implicações na logística de distribuição do mesmo. O objetivo alcançado era vislumbrar e contribuir sob a ótica dos fatores (condicionantes) que afetam a demanda do etanol brasileiro nos próximos anos. Foi verificado como os condicionantes afetam de forma complexa em uma teia de relações de causa e efeito, que não tem fim nem começo mas inferem interações mútuas. Conseguiu-se também avaliar cenários de expansão da demanda do etanol brasileiro com base em premissas de evolução causal dos principais condicionantes ao crescimento. Além disso, foi possível desenvolver a percepção marginal dos impactos e necessidades logísticas para o atendimento à demanda.

Avaliações que seguiriam a lógica deste trabalho seriam simulações para otimização de rotas, modais, tempos, recursos, custos e investimentos. Neste quesito vários trabalhos têm sido realizados utilizando métodos numéricos, programação linear e técnicas de inteligência artificial, entre outros como, por exemplo, o trabalho desenvolvido por Rodrigues S. B. M, 2007. Estes estudos são fundamentais e necessários para a viabilização de investimentos. Como discutido ao longo do trabalho atual, o sucesso futuro do etanol brasileiro como commodity internacional está diretamente relacionado à otimização de custos, recursos e investimentos.

Para estudos futuros, é sugerido também desenvolver trabalhos que envolvam mais a complexidade das interações entre os condicionantes da demanda, simulando diferentes cenários e medindo a "força" das interações. Estudos têm sido feitos envolvendo a geração de cenários preditivos/ econométricos e também prospectivos/ adaptativos para projeção de demandas e expansão do setor. Como exemplos os estudos realizados por Moreira, 2008 e Carvalho et al, 2008.

No presente trabalho não foi abordado um cenário pessimista, que poderia elucidar perspectivas de manutenção ou diminuição da demanda. Estudos com este intuito poderiam avaliar riscos e possíveis planos de contingência aos agentes envolvidos no setor sucroalcooleiro. Desta forma, sugere-se realizar estudos desta natureza.

Quanto maior a confiança e visibilidade do futuro do etanol, maior será efetivamente a garantia do sucesso do etanol no Brasil e no mundo. 


\section{REFERÊNCIAS BIBLIOGRÁFICAS}

ANDRIOLLI, M., Análise de viabilidade econômico financeira de alcooldutos no Brasil. Dissertação ( Mestrado em economia aplicada). Escola Superior de Agricultura "Luiz de Queiroz" , Universidade de São Paulo, Piracicaba, 2009.

AGÊNCIA NACIONAL DE ENERGIA ELÉTRICA. Banco de informações de Geração. Brasília: ANEEL, 2007.

AGÊNCIA NACIONAL DO PETRÓLEO. Anuário Estatístico Brasileiro do petróleo, gás natural e biocombustíveis. Brasília: ANP, 2008.

BASTOS, V. D., Etanol, alcoolquímica e biorrefinarias. BNDES setorial, Rio de Janeiro, n. 25 , p. 5-38, mar. 2007.

BIAGI, F. M. , Setor sucroalcooleiro e o capital estrangeiro. O Estado de São Paulo, São Paulo, 28 de Dezembro de 2009. p. A2.

BUAINAIN A. B . et al, Produção Brasileira de cana-de-açúcar e deslocamento da fronteira agrícola no estado do mato Grosso. Informações Econômicas, SP, v.38, n.4, abr. 2008.

CARVALHO, F. A. et al, O método de análise de cenários aplicado ao agronegócio do etanol interpretado a partir da abordagem sistêmica. $4^{\mathbf{0}}$ Congresso Brasileiro de Sistemas, UniFacef, Franca, São Paulo, 2008.

COLIN, J., SANTOS, E. M., TAIOLI, F., A comparative analysis between Brazil and the USA in ethanol logistics, IEE-USP, São Paulo, 2009.

COSAN. Disponível em: < http://www.cosan.com.br/rumo/index_pti.html> Acesso em: 27 dez. 2009.

ENERGY INFORMATION ADMINISTRATION. Disponível em: <http://www.eia.doe.gov/cneaf/alternate/page/atftables/afv_atf.html\#supplied> Acesso em: 29 dez. 2009. 
EMPRESA DE PESQUISA ENERGÉTICA . Perspectivas para o Etanol no Brasil. Brasília: EPE, 2008.

FIGUEIRA, S. R., BURNQUIST, H. L., Perspectivas para o setor sucroalcooleiro brasileiro nos programas de álcool combustível da União Européia, Japão e Brasil. ESALQ: Piracicaba, São Paulo, 2008.

FIGUEIREDO, R. Gargalos logísticos na distribuição brasileira de combustíveis. Rio de Janeiro: COPPE/UFRJ, 2005. Artigo, Centro de Estudos de Logística.

FUNDAÇÃO SEADE. Pesquisa de Investimentos Anunciados no Estado de São Paulo . São Paulo: FIESP.2007 .

GOLDEMBERG, J., O etanol de cana vai tomar conta do mundo. Revista oficial Ethanol Summit, 2009., São Paulo : ÚNICA, 2009.

GlOBO. Disponível em : <http://oglobo.globo.com/economia/mat/2010/01/11/governo-reduzmistura-de-etanol-na-gasolina-para-20-915504981.asp> Acesso em: 14 jan. 2010

INSTITUTO BRASILEIRO DE GEOGRAFIA E ESTATÍSTICA. Indicadores de desenvolvimento sustentável - Brasil . Brasília: IBGE, 2004

Indicadores da produção agrícola, estatística da produção agrícola. Brasília: IBGE, Setembro de 2009, p.20.

.Disponível em: <http:// WWW.ibge.org.br> Acesso em Out. 2009

JANK, M.S., Etanol : benefícios, riscos e desafio . O Estado de São Paulo, São Paulo, 6 de Novembro 2009, p. A2.

KNIGHT , P.. The changing structure of the sugar and ethanol industry in Brazil. F.O. Licht's World Ethanol \& Biofuels. Report, 07 de Julho de 2009.

KOTLER, P. Administração de marketing. 10 ed. : São Paulo: Prentice Hall, 2000. Cap.3 , p. 95.

LDC. Disponível em :

http://www2.vagas.com.br/PagEmpr.asp?e=louisdreyfuscommodities351> Acesso em: 05 jan. 2010. 
MACEDO, I. C., NOGUEIRA, L. A. H., Avaliação da expansão do etanol no Brasil. Brasília: Centro de Gestão e Estudos Estratégicos, Julho de 2004.

MAGOSSI E. Cosan suspende projetos de construção de novas usinas. O Estado de São Paulo, 11 de Setembro de 2009, p. B14.

MAGOSSI E. ETH fecha acordo para se unir á Brenco. Estado de São Paulo, 9 de Out. 2009. p. B15.

MINISTÉRIO DA AGRICULTURA PECUÁRIA E ABASTECIMENTO. Balanço nacional da cana-de-açúcar e Agroenergia. Brasília, 2007

Anuário Estatístico da Agroenergia. Brasília, 2009.

MINISTÉRIO DAS MINAS E ENERGIA. Balanço Energético Nacional: relatório preliminar. Brasília, 2009.

MOREIRA, M. M. R., Análise prospectiva do padrão de expansão do setor sucroenergético brasileiro: uma aplicação de modelos probabilísticos com dados georeferenciados. Dissertação de mestrado ( mestrado em economia ), Universidade de São Paulo, FEA, São Paulo SP, 2008.

PIACENTE, E. A. Perspectivas do Brasil no mercado internacional de etanol. Dissertação (Mestrado em engenharia mecânica), Universidade Estadual de Campinas, Campinas, 2006.

QUEIROZ, M. S., Biocombustíveis e a economia brasileira. In: CONFERÊNCIA

NACIONAL DE BIOENERGIA_2007, São Paulo. Bioconfe Anais. São Paulo, 2007.p.22.

RODRIGUES, S.B.M., Avaliação de alternativas de transporte de etanol para exportação na região centro sul. Dissertação (Mestrado) - Escola de Engenharia de São Carlos, Universidade de São Paulo, São Paulo, 2007

RODRIGUES, T. R.. Perspectivas da expansão e investimentos na rede de alcooldutos. In: SEMINÁRIO ALCOOLDUTOS, 2009. São Paulo. Anais. 2009.

REJOWSKI, R. J., Otimização da programação de operações dutoviárias: formulações eficientes e considerações hidráulicas. Tese (Doutorado em engenharia )- Escola Politécnica , Universidade de São Paulo, São Paulo, 2007.

SCARAMUZZO, M., LDC-SEV traça planos para novas usinas, Valor Econômico, 28 Outubro de 2009. p.B13. 
SILVA, C. R. U. Balanço de energia e das emissões de gases de efeito estufa na cadeia produtiva do etanol brasileiro. Dissertação ( Mestrado em engenharia mecânica)-, Universidade Estadual de Campinas, Campinas, 2009.

SINDICATO NACIONAL DAS EMPRESAS DISTRIBUIDORAS DE COMBUSTÍVEIS E DE LUBRIFICANTES. O programa brasileiro, três décadas depois. São Paulo: SINDICOM, 2007.

TEIXEIRA, S.C. et al. A Sustentabilidade da Expansão da Cultura Canavieira. Cadernos Técnicos da Associação Nacional de Transportes Públicos , v. 6, Jul. 2007.

UNIÃO DAS INDÚSTRIAS CANAVIEIRAS DE SÃO PAULO. Avaliação da área de cana. Disponível em: 〈http://www.unica.com.br/downloads/estatisticas/canasat_2008.pdf> Acesso em: 10 set. 2009.

Global sustainable Biofuels : the role of sugarcane ethanol. FO Lichts Ethanol leaders Summit, Paris, 03 Nov. 2009.

Dados e Cotações - Estatísticas. Disponível em:

〈http://www.unica.com.br/dadosCotacao/estatistica/> . Acesso em: 10 jan. 2010.

UNIDUTO- Apresentação Uniduto. In:Seminário sobre alcooldutos, IIR - Informa, São Paulo, Novembro de 2009.

US DEPARTMENT OF ENERGY. Energy. Sources: oil. Disponível em: <http://www.energy.gov/energysources/oil.htm>. Acesso em: 29 dez. 2009.

XAVIER, M. Biocombustíveis : mercado interno, mercado internacional, logística e distribuição. São Paulo: FIESP, 2007. 